\title{
Geohydrologic Reconnaissance of the Upper Potomac River Basin
}

GEOLOGICAL SURVEY WATER-SUPPLY PAPER 2035

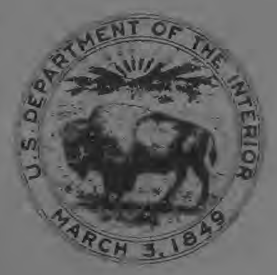




\section{Geohydrologic Reconnaissance of the Upper Potomac River Basin}

By FRANK W. TRAINER and FRANK A. WATKINS, JR.

GEOLOGICAL SURVEY WATER-SUPPLY PAPER 2035

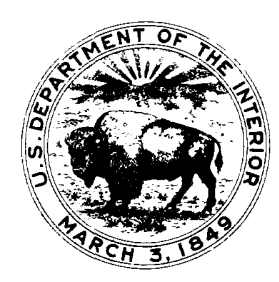




\section{UNITED STATES DEPARTMENT OF THE INTERIOR \\ ROGERS C. B. MORTON, Secretary}

\section{GEOLOGICAL SURVEY}

V. E. McKelvey, Director

Library of Congress catalog-card No. 75-600021

For sale by the Superintendent of Documents, U.S. Government Printing Office Washington, D.C. 20402

Stock Number 024-001-02630-9 


\section{CONTENTS}

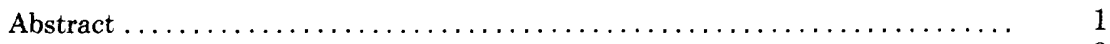

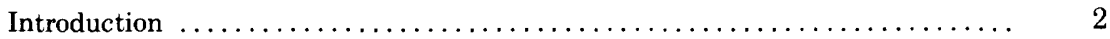

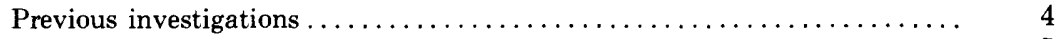

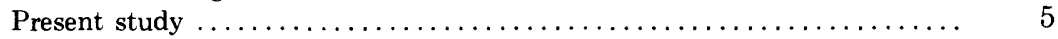

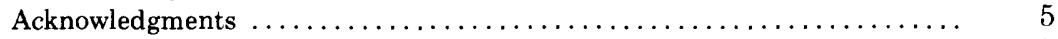

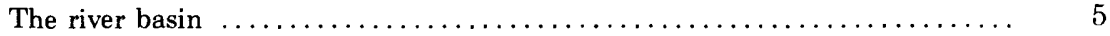

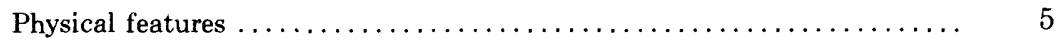

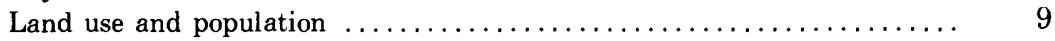

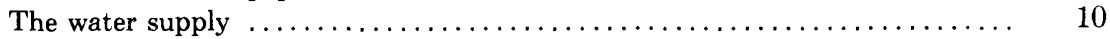

Precipitation $\ldots \ldots \ldots \ldots \ldots \ldots \ldots \ldots \ldots \ldots \ldots \ldots \ldots \ldots \ldots \ldots \ldots \ldots$

Temperature and evapotranspiration $\ldots \ldots \ldots \ldots \ldots \ldots \ldots \ldots \ldots \ldots \ldots \ldots$

Runoff $\ldots \ldots \ldots \ldots \ldots \ldots \ldots \ldots \ldots \ldots \ldots \ldots \ldots \ldots \ldots \ldots \ldots \ldots \ldots \ldots$

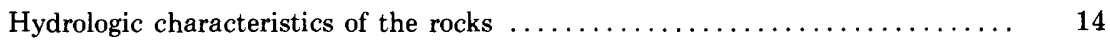

Estimates based on pumping tests $\ldots \ldots \ldots \ldots \ldots \ldots \ldots \ldots \ldots \ldots \ldots \ldots$

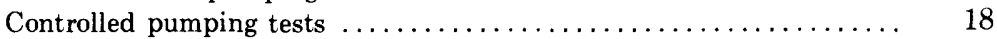

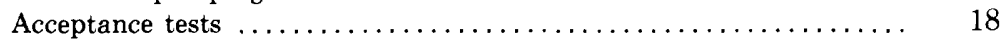

Estimates based on fluctuation of the water table $\ldots \ldots \ldots \ldots \ldots \ldots \ldots \ldots . \ldots 21$

Estimates based on ground-water recession $\ldots \ldots \ldots \ldots \ldots \ldots \ldots \ldots \ldots \ldots \ldots 25$

Estimates based on the gradient of the water table $\ldots \ldots \ldots \ldots \ldots \ldots \ldots \ldots$

Estimates based on base-runoff recession $\ldots \ldots \ldots \ldots \ldots \ldots \ldots \ldots \ldots \ldots \ldots$

Effect of duration of streamflow recession $\ldots \ldots \ldots \ldots \ldots \ldots \ldots$

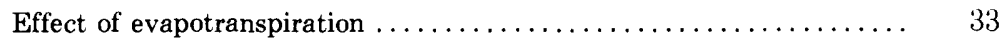

Complexity of recession curves $\ldots \ldots \ldots \ldots \ldots \ldots \ldots \ldots \ldots \ldots \ldots \ldots \ldots$

Estimates of aquifer characteristics $\ldots \ldots \ldots \ldots \ldots \ldots \ldots \ldots \ldots \ldots \ldots \ldots \ldots$

Summary of hydraulic characteristics $\ldots \ldots \ldots \ldots \ldots \ldots \ldots \ldots \ldots \ldots \ldots \ldots$

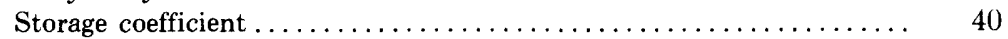

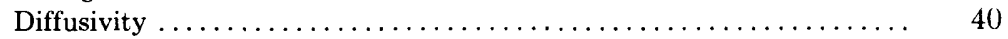

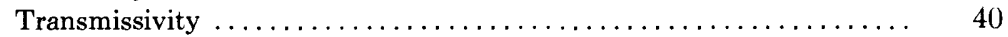

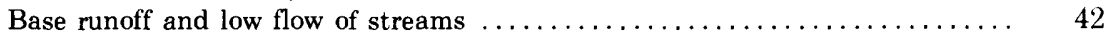

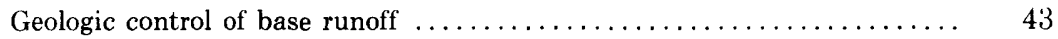

Base runoff and low flow from small basins $\ldots \ldots \ldots \ldots \ldots \ldots \ldots \ldots$

Low flow in geohydrologic terranes $\ldots \ldots \ldots \ldots \ldots \ldots \ldots \ldots \ldots \ldots \ldots$

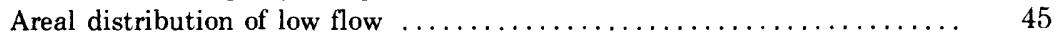

Ground water and water management ...................... 49

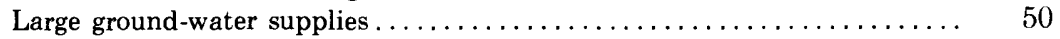

Manipulation of ground-water storage $\ldots \ldots \ldots \ldots \ldots \ldots \ldots \ldots \ldots \ldots \ldots$

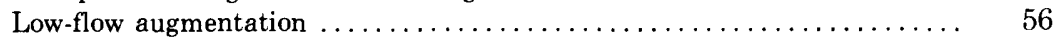

Chemical quality of the ground water $\ldots \ldots \ldots \ldots \ldots \ldots \ldots \ldots \ldots \ldots \ldots \ldots$

Chemical quality as related to low-flow augmentation $\ldots \ldots \ldots \ldots \ldots \ldots$

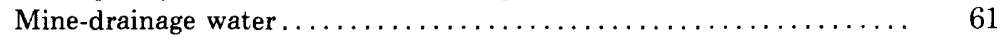

Mineralized ground water $\ldots \ldots \ldots \ldots \ldots \ldots \ldots \ldots \ldots \ldots \ldots \ldots \ldots$

Nitrate in ground water in the Appalachian Valley ............ 63

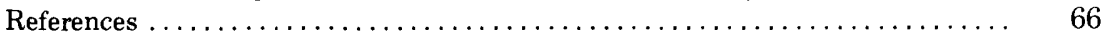




\section{ILLUSTRATIONS}

Plate 1. Map showing altitude and configuration of water table and

Page nitrate concentration in ground water in the lowland part of the Appalachian Valley, upper Potomac River basin

In pocket

FIGURE 1. Map showing location of the upper Potomac River basin ......... 6

2. Map showing physiographic and hydrologic provinces ........... 7

3. Map showing average annual precipitation, $1947-67 \ldots \ldots \ldots \ldots \ldots 11$

4. Graph showing annual precipitation and potential evapotranspiration at Seabrook, N.J. ...................... 13

5. Hydrographs and graph showing precipitation, $1948 \ldots \ldots \ldots \ldots \ldots \ldots 15$

6. Graphs showing distribution of values of transmissivity with respect to depth of well penetration and distance from stream .................................... 22

7. Recession segments in ground-water hydrographs $\ldots \ldots \ldots \ldots \ldots \ldots 27$

8. Base-runoff recession curves for Passage Creek at Buckton, Va., and for South Branch Potomac River at Franklin, W. Va.

9. Graphs showing relation of $M_{7,10}$ to $M_{7,2}$ in three geo-

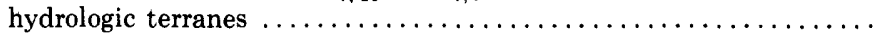

10. Map showing areal changes in selected stream flow charac-

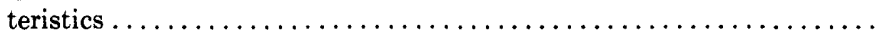

11. Map showing ranking of tributary basins in terms of 7 -day minimum average streamflow at 20 -year recurrence

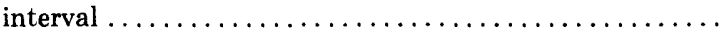

12. Graphs showing frequency distribution of values of specific capacity of wells in carbonate and noncarbonate rocks .......... 52

13. Map showing principal areas of outcrop of carbonate rock ......... 53

14. Map showing regional pattern of chemical composition of dissolved load in stream water ........................ 60

15. Histograms showing hardness of ground water $\ldots \ldots \ldots \ldots \ldots \ldots \ldots, 62$

16. Histogram showing frequency distribution of the concentration of nitrate in ground water in the Appalachian Valley, February and March 1970

\section{TABLES}

T ABLE 1. Average temperature at representative localities in the upper Potomac River basin ..................... 12

2. Multiple-well aquifer tests in Maryland $\ldots \ldots \ldots \ldots \ldots \ldots \ldots \ldots \ldots \ldots \ldots$

3. Single-well aquifer tests ................................ 19

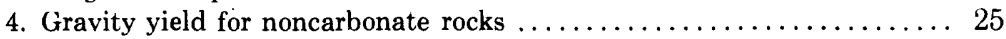

5. Aquifer diffusivity estimated from recession of groundwater level in wells ............................... 28

6. Estimates of transmissivity determined using computed recharge values for water-level profiles in the Appalachian Valley 
$\mathrm{T}_{\text {ABLE }}$ 7. Descriptors for slopes of base-runoff recession curves and spring base runoff for selected tributary basins $\ldots \ldots \ldots \ldots \ldots 38$

8. Summary of hydraulic characteristics of rocks in the upper Potomac River basin 41

9. Base runoff and low flow from representative small

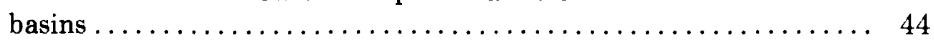

10. Low flow from representative tributary basins 46 


\title{
GEOHYDROLOGIC RECONNAISSANCE OF THE UPPER POTOMAC RIVER BASIN
}

\author{
By Frank W. Trainer and Frank A. Watkins, Jr.
}

\section{ABSTRACT}

The upper Potomac River basin, in the central Appalachian region in Pennsylvania, Maryland, Virginia, and West Virginia, is a humid temperate region of diverse fractured rocks. Three geohydrologic terranes, which underlie large parts of the basin, are described in terms of their aquifer characteristics and of the magnitude and duration of their base runoff: (1) fractured rock having a thin regolith, (2) fractured rock having a thick regolith, and (3) carbonate rock.

Crystalline rock in the mountainous part of the Blue Ridge province and shale with tight sandstone in the folded Appalachians are covered with thin regolith. Water is stored in and moves through fairly unmodified fractures. Average transmissivity $(T)$ is estimated to be 150 feet squared per day, and average storage coefficient $(S), 0.005$. Base runoff declines rapidly from its high levels during spring and is poorly sustained during the summer season of high evapotranspiration. The rocks in this geohydrologic terrane are the least effective in the basin for the development of water supplies and as a source of dry-weather streamflow.

Crystalline and sedimentary rocks in the Piedmont province and in the lowland part of the Blue Ridge province are covered with thick regolith. Water is stored in and moves through both the regolith and the underlying fractured rock. Estimated average values for aquifer characteristics are $T, 200$ feet squared per day, and $S, 0.01$. Base runoff is better sustained in this terrane than in the thin-regolith terrane and on the average is about twice as great.

Carbonate rock, in which fractures have been widened selectively by solution, especially near streams, has estimated average aquifer characteristics of $T, 500$ feet squared per day, and $S, 0.03-0.04$. This rock is the most effective in the basin in terms of water supply and base runoff. Where its fractures have not been widened by solution, the carbonate rock is a fractured-rock aquifer much like the noncarbonate rock. At low values the frequency of specific capacities of wells is much the same in all rocks in the basin, but high values of specific capacity are as much as 10 times more frequent in carbonate rock than in noncarbonate rock. Nearly all the large springs and high-capacity wells in the basin are in carbonate rock. Base runoff from the carbonate rock is better sustained during dry weather and on the average is about three times as great as base runoff from fractured rock having a thin regolith.

The potential role of these water-bearing terranes in water management probably lies in the local development of large water supplies from the carbonate rock and in the possible manipulation of underground storage for such purposes as providing space for artificial recharge of ground water and providing ground water to be used for the augmentation of low streamflow. The chief water-quality problems in the basin-acidic minedrainage water in the western part of the basin, local highly mineralized ground water, and the high nitrate content of ground water in some of the densely populated parts of the basin-would probably have little adverse affect on the use of ground water for low-flow augmentation. 


\section{INTRODUCTION}

The Potomac River and its major tributaries are the chief source of water supply for the larger communities in its basin. The greatest use of water is concentrated in the Washington, D.C., metropolitan area, near the downstream end of the basin. In addition to being a source of supply, the river also serves as the vehicle for disposal of waste waters from all these communities. River flow has been adequate to serve this twofold function during winter and spring and, in most years, during summer and autumn. However, water requirements for public supply and for dilution of effluents have been increasing, and during the drought of the early to middle sixties (most notably in 1966) annual low flows of the Potomac River declined to levels that were critically low for these combined needs. The water emergency was ameliorated in the late sixties by higher precipitation and higher streamflow. The experience of the drought, together with steadily growing water needs (particularly in the Washington metropolitan area and increasingly in upstream communities), suggests that the low dry-weather flow of the river during late summer and early autumn will present one of the most pressing water-management problems in the Potomac River basin.

Decline in streamflow is conspicuous during droughts. A smaller decline occurs each summer because of normal losses of water to evaporation and transpiration. In winter, little water evaporates, and plants are quiescent; soil moisture, ground-water storage, and streamflow are all high, and the basin experiences a temporary water surplus. But in summer the air temperature is high, evaporation is rapid, and plants consume and transpire great quantities of water. In dry years there may be a summer water shortage in the basin.

Streamflow in the Potomac River basin is provided by direct runoff from the land surface and by subsurface discharge into the stream channels. During periods between storms, the flow is from storage of stream water in the channels and from ground-water storage. During extended dry periods, ground water provides almost all the streamflow. Effective management of low streamflows, therefore, requires thorough understanding of the conditions of ground-water storage and flow in the basin.

The necessity for management of water resources in areas of dense population is widely recognized. In some areas, the land surface is so permeable and the ground-water reservoir so productive that water supply is readily obtained from wells or springs. In other regions, the land surface is so impervious and the ground-water reservoir is of such Iow capacity that large water supplies must be obtained from streams, and impoundments are used to bridge seasons of short supply. Management problems, relating to both the availability and the quality of the 
water, are very different in these two types of regions.

The upper Potomac River basin is in a class intermediate between these extreme types. Ground water provides adequate domestic and farm water supplies nearly everywhere; locally, it provides large supplies for industrial and municipal use. Most communities in the basin rely on streams for their water supply or on a combination of underground and surface sources. The larger municipal supplies, including those from the Potomac for use in the Washington area, are drawn from streams with little or no impoundment, and it is these supplies that were most endangered during the summer low-water period in 1966 . The construction of several reservoirs in the basin is authorized, planned, or under discussion; water supply and low-flow augmentation are among the principal purposes of several of the proposed reservoirs.

One of the water-management practices now being widely discussed as potentially useful in the maintenance of streamflow during late summer is low-flow augmentation through the pumping of ground water into streams. Manipulation of ground-water storage capacity, using alternate periods of storage and discharge, is a promising technique of management that has not been extensively used in the eastern United States. In general terms, this approach to low-flow augmentation depends (1) on pumping ground water for short periods, perhaps a few weeks, at places where the withdrawal will not induce infiltration of river water to the ground and (2) on natural recovery of the groundwater level during the subsequent autumn-winter period of natural ground-water recharge. Successful use of this method would thus depend on an understanding of ground-water storage and of the nature and effectiveness of interconnection of the ground-water reservoir and the streams.

Ground-water studies have been made during the past 40 years in several parts of the Potomac River basin. Results of these studies show a great range in the availability of ground water, large supplies being found only locally. The extensive streamflow data available also show large areal differences in hydrology and a considerable range in base runoff among tributary basins. Although large parts of the basin have not been covered by the ground-water studies and many of the streams have not been measured, conclusions drawn from the regions studied so far are probably valid for similar terranes in the rest of the basin. The present report, based on this published work and on new studies, is a reconnaissance of ground water and the base runoff of streams in the upper Potomac River basin. Its purpose is the investigation of the relation of base runoff to ground-water hydrology in a region of fractured rocks. It is hoped that the knowledge gained will be applicable to ground-water modeling and other studies related to water management in the basin. 


\section{PREVIOUS INVESTIGATIONS}

The upper Potomac River basin is in the classic Appalachian region, where many pioneering geologic studies were made. These works, and many later investigations in areal geology, stratigraphy, and structural geology, provide background for study of the geohydrology of the upper Potomac River basin. Much of the result of these works is summarized in geologic maps recently compiled and published in each State in the basin (Maryland Geol. Survey, 1968; Pennsylvania Topog. and Geol. Survey, 1960; Virginia Div. Mineral Resources, 1963; West Virginia Geol. and Econ. Survey, 1968).

An extensive network of weather-data stations has long been maintained by the U.S. Weather Bureau (now the Environmental Data Service of the National Oceanic and Atmospheric Administration). About 70 stations, for daily observation of temperature and precipitation, are in or adjacent to the upper Potomac River basin. The Geological Survey maintains about 70 continuous-record stations in the basin for the measurement of streamflow, and records are also available for many additional stations at which data collection has been discontinued or is no longer carried on continuously. There is thus a considerable amount of data on the supply of water to and runoff from the basin.

Several areal reports have treated the occurrence of ground water in the basin. Amsden, Overbeck, and Martin (1954) and Slaughter and Darling (1962) described much of the part of the basin that lies in the Appalachian Plateaus. Bieber (1961), Cady (1936), Slaughter and Darling (1962), and Hobba, Friel, and Chish the Valley and Ridge province. Cady (1938), Dingman, Meyer, and Martin (1954), Johnston (1962), Meyer and Beall (1958), and Nutter and Otton (1969) discussed ground water in parts of the Piedmont province. Nutter (1973) discussed ground water in parts of the Piedmont province and of the Appalachian Valley. Johnston, Pollock, and Weist (1962) summarized the occurrence of ground water in the entire Potomac River basin, including the downstream part that lies in the Atlantic Coastal Plain.

Extensive sampling for temperature and inorganic chemical quality of water has been done in several parts of the basin. Data relating to surface water have been published in Connor and Schroeder (1957), Doll, Meyer, and Archer (1963), Kapustka (1957), Virginia Division of Water Resources (1960), and annual volumes of the Geological Survey's Water-Supply Paper series "Quality of Surface Waters of the United States." Thomas (1966) summarized data of Maryland streams. (Other analyses, such as those relating to bacteriology, organic-chemical constituents, or sediment, have been made by the Environmental Protection Agency, by State health agencies, and by the Geological Survey. These analyses are not considered in this report.) The ground-water 
reports cited in the preceding paragraph contain data on the temperature and chemical quality of ground water, and special problems in ground-water quality were discussed by Clark (1969) and Meyer (1960).

\section{PRESENT STUDY}

This investigation is concerned with the occurrence of ground water, particularly as it is related to streamflow. Study of the ground water, based partly on previous work and partly on new investigations, concerns the storage and transmission characteristics of the rocks, the relation of streamflow to water-table fluctations, and the chemical quality of the ground water. Streamflow from tributary basins was studied to determine the base runoff from representative types of rock. This phase of the study was based largely on data from the gaging-station network of the Geological Survey, but many miscellaneous streamflow measurements were made to supplement those data because few of the gaged tributary basins are underlain by a single type of rock.

\section{ACKNOWLEDGMENTS}

This investigation could not have been made without the cooperation and assistance of many landowners, industry officials, and officials of local, State, and Federal government agencies. Well drillers $\mathrm{H}$. Singhas, Middleburg, Va., and Sydnor Hydrodynamics, Richmond, Va., furnished information on wells. The following officials and their staffs provided well records and other data: Kenneth N. Weaver, Maryland Geological Survey; Robert B. Erwin, West Virginia Geological and Economic Survey; Julian M. Alexander, Virginia Division of Water Resources; and James L. Calver, Virginia Divsion of Mineral Resources. Many private landowners kindly permitted access to wells, springs, and streams. Among those who assisted us in the field, special thanks go to D. J. Cederstrom, L. E. Burgess, W. S. Wetterhall, C. C. Campion, F. L. Snow, H. M. Peyton, N. E. McClymonds, and S. W. Carmalt, all of the Geological Survey.

\section{THE RIVER BASIN}

\section{PHYSICAL FEATURES}

The Potomac River drains part of the middle Atlantic coastal region and flows into Chesapeake Bay. This report considers the river basin upstream from Washington, D. C., an area of 11,560 square miles which lies in West Virginia, Virginia, Maryland, and Pennsylvania (fig. 1) and is here termed the "upper Potomac River basin."

The central part of the upper Potomac River basin, about threequarters of it, is in the Valley and Ridge physiographic province; the western part, in Pennsylvania, Maryland, and West Virginia, is in the Appalachian Plateaus province; and the eastern part, about one-sixth of the basin, is in the Blue Ridge and Piedmont provinces, extending 


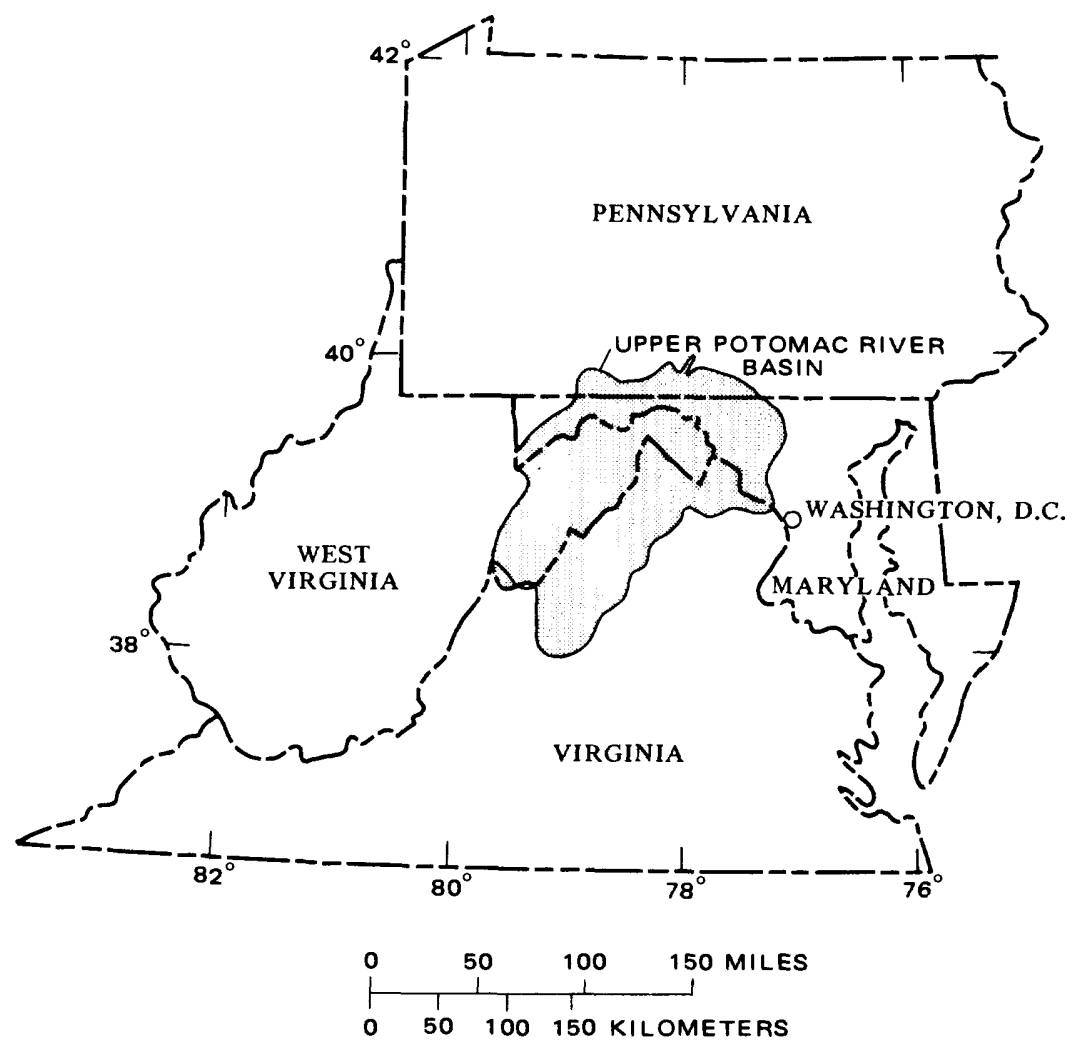

Figure 1.-Location of the upper Potomac River basin.

nearly to the Atlantic Coastal Plain in Maryland and Virginia. The dominant northeast strike of the inclined rock strata has led to development of prominent ridges and valleys which trend northeastward. The principal tributary streams flow northeast or southwest to the Potomac River.

The westernmost principal member of the river system, the North Branch Potomac River (fig. 2), rises in the Appalachian Plateaus in Maryland and West Virginia. The Plateaus are underlain by horizontally bedded sedimentary rocks-sandstone, shale, limestone, and coal. The region has been deeply dissected, and the terrain is mountainous; relief is commonly 500 to 1,000 feet along the North Branch Potomac River in the Plateaus, and it is as great as 2,000 feet at the east edge of the Plateaus.

The Valley and Ridge province is underlain by folded sedimentary strata-shale, sandstone, and carbonate rock-eroded to form alternating valleys and ridges. The thickness of layers or sequences of layers dominated by one rock type ranges from a few tens of feet to several 

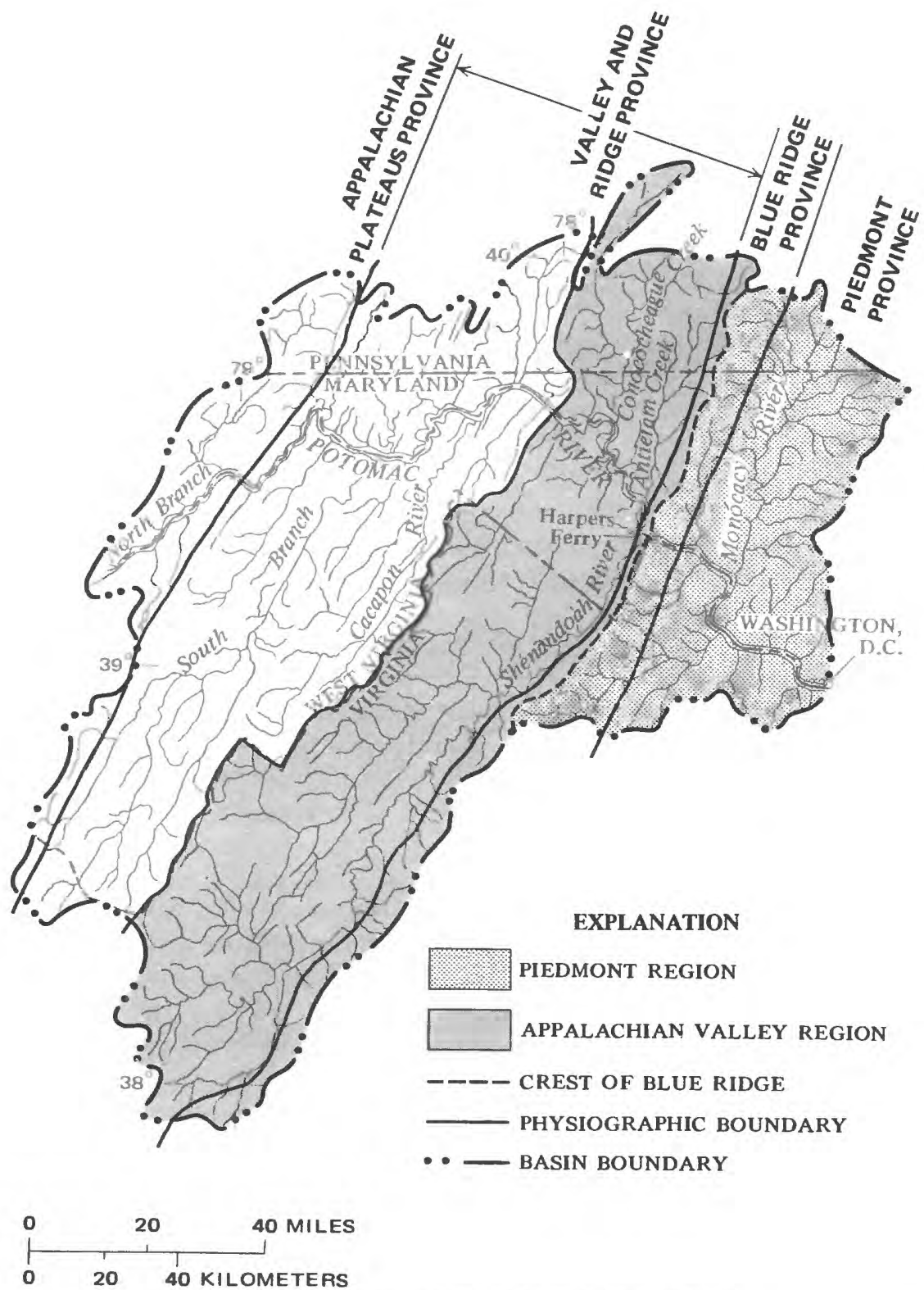

Figure 2.-Physiographic and hydrologic provinces.

thousand feet. Contrasts in rock type and in thickness and inclination of strata have led to development of terrain that is complex in terms of the relation between rocks and water. The chief tributary streams in this province (fig. 2)-South Branch Potomac River and Cacapon River 
in West Virginia, Conococheague and Antietam Creeks in Pennsylvania and Maryland, and the Shenandoah River in Virginia and West Virginia-all drain more than one of the principal rock types. Only the basins of smaller tributaries are underlain by a single type of rock.

Although the entire Valley and Ridge province is a physiographic unit broadly characterized by similar geology, it is conveniently subdivided into two parts: a western part that comprises many linear mountains or ridges and intervening narrow valleys; and an eastern part, a broad valley that is part of the Appalachian Valley extending from Pennsylvania to Alabama. The western part is rugged; landsurface relief is typically 500 to 1,000 feet or more. In the eastern part, where the valley is commonly 15 to 20 miles wide, relief is as little as 100 to 200 feet over extensive areas. These two regions also differ somewhat in their underlying rocks. The western part is largely underlain by shale and sandstone, although the principal tributary streams in West Virginia, the South Branch Potomac River and the Cacapon River, drain carbonate rock in their headwater areas. The Appalachian Valley, on the other hand, is underlain by large areas of carbonate rock.

The Blue Ridge, whose principal crests commonly stand 1,500 to 2,500 feet above the lowlands to either side, is a mountain mass of crystalline rock. It is a complex of ridges, with prominent northeast trending valleys between some of them; its total width is commonly 8 to 10 miles or more. The Blue Ridge Mountains form the southeast boundary of the Potomac River basin in much of northern Virginia. In northernmost Virginia, Maryland, and southern Pennsylvania, however, the Blue Ridge Mountains are a principal divide within the upper Potomac River basin; all streamflow from west of the Blue Ridge Mountains flows through the gap at Harpers Ferry, W.Va. Most streams in the Blue Ridge are headwater tributaries of larger streams in the Valley and Ridge province or in the Piedmont; but several streams, in large interridge valleys, flow directly into the Potomac River.

The Piedmont province is a region of gently rolling terrain and low relief. Crystalline rocks underlie the eastern part of the region, the "Piedmont Upland." To the west, in a northeast-trending lowland between the crystalline rocks and the Blue Ridge, the rocks are chiefly sandstone, shale, and limestone. The principal stream in this region, the Monocacy River, flows down this lowland in Pennsylvania and Maryland.

The physiographic provinces provide a logical basis for study of the hydrology of the basin, but minor modifications in boundaries are desirable to take account of the major tributary stream systems. For example, the mountain belt of the Blue Ridge differs geologically and topographically from the Piedmont to the east and from the Valley and Ridge province to the west. However, the Blue Ridge crest is the promi- 
nent drainage divide separating a smaller area of mountainous terrain which drains to the west from a larger area which drains to the east. More logical hydrologic provinces are the Piedmont, whose western headwater drainage areas extend to the principal divide in the Blue Ridge, and the Appalachian Valley, whose eastern headwater drainage areas extend to the divide in the Blue Ridge. The Appalachian Valley, for reasons of topography, drainage, and ground-water conditions, is logically distinguished from the remainder of the Valley and Ridge province to the west.

The upper Potomac River basin is conveniently divided into four hydrologic provinces (fig. 2), which are, from the headwaters, or western part, of the basin eastward:

1. The Appalachian Plateaus, a region of deep narrow valleys cut into flat-lying sandstone and shale. This province constitutes about 15 percent of the upper Potomac River basin.

2. The western part of the Valley and Ridge physiographic province, a region of narrow ridges and valleys underlain predominantly by sandstone and shale. It constitutes about 30 percent of the basin.

3. The Appalachian Valley, a region underlain by carbonate rock and shale in its lowland parts and by sandstone and shale in its upland drainage areas. Including these upland areas, it constitutes about 35 percent of the basin.

4. The Piedmont, a region underlain by crystalline and subordinate sedimentary rocks. It constitutes about 20 percent of the basin.

\section{LAND USE AND POPULATION}

The upper Potomac River basin is predominantly rural. A large part of it, especially in the east, has been farmed, and we estimate from measurements on topographic maps that about 4,700 square miles, or 41 percent of it, is now cleared land. Part of the remainder was farmed in the past but has been allowed to go back to forest; the rest has not been farmed, although the original forest has been cut in almost all of it. Most of the cleared land is cultivated or is in orchard or pasture. Part of it is in towns, and a small but rapidly growing part is being occupied by housing developments near existing communities and by rural settlement along the highways. Nearly 90 percent of the cleared land is in the Piedmont province and the Appalachian Valley.

On the basis of the 1970 census population data for counties and the larger communities, we estimate that 1 million people live in the upper Potomac River basin. Of this total, about 40 percent live in the Piedmont-Blue Ridge region and about 40 percent, in the Appalachian Valley. About 16 percent live in the western Valley and Ridge region, and the remaining 4 percent in the Appalachian Plateaus. Topography, transportation routes, and present patterns of population and industry seem to favor continuation of population growth upon this same areal 
pattern. This conclusion suggests that the greater part of the future need for water in the upper Potomac River basin will continue to be concentrated in the Piedmont region and the Appalachian Valley. If the Washington metropolitan area, just downstream from the upper Potomac River basin, is included in this areal projection of need, future water use in this region will be concentrated overwhelmingly toward the downstream end of the river system.

\section{THE WATER SUPPLY}

The outer part of the earth's crust, at and below the land surface, is a great reservoir for the storage and transmission of water. The workings of this reservoir depend broadly on three factors-the water supplied to the reservoir and removed from it, the reservoir itself, and man's activities. The supply of water is a function of climate. The nature of the reservoir depends principally on the character and distribution of openings in the rocks below the surface and on the topography, soil, and vegetation at the surface. The human effect is manifold and widespread. In a simplified view, we can consider the earth as a relatively stable element in this system, changing only slowly. Climate can also be considered a relatively stable element; it is characterized by numerous short-term fluctuations about average trends, which are themselves changing slowly. The effects of man's activities have been small during most of his history but are becoming larger and more common, and they can be expected to become larger and more pervasive as time goes on.

\section{PRECIPITATION}

In the upper Potomac River basin the average annual precipitation ranges from 32 to 55 inches. Precipitation is commonly somewhat greater in summer than in winter, but there is no marked seasonal concentration of precipitation. Much of the winter precipitation is snow, particularly in the higher parts of the basin, but because of repeated winter thaws the snow cover does not last through the winter. In most parts of the basin, periods of continuous snow cover are a few days to a few weeks long.

Figure 3 shows the distribution of mean annual precipitation over the upper Potomac River basin during 1947-67. The northeast trend of the isohyets conforms broadly with the topographic grain of the region. The highest annual precipitation, 45 to 55 inches, is on the Appalachian Plateaus in the headwaters region of the North Branch Potomac River. An extensive area of relatively low precipitation in the lower mountains in the west-central part of the basin extends northeastward from West Virginia and Virginia into Pennsylvania. Average annual values of about 32 inches are recorded at several places within the area of the closed 35-inch isohyet in figure 3 . This area of low precipitation is probably a rain shadow in the lee of the Appalachian Plateaus. 


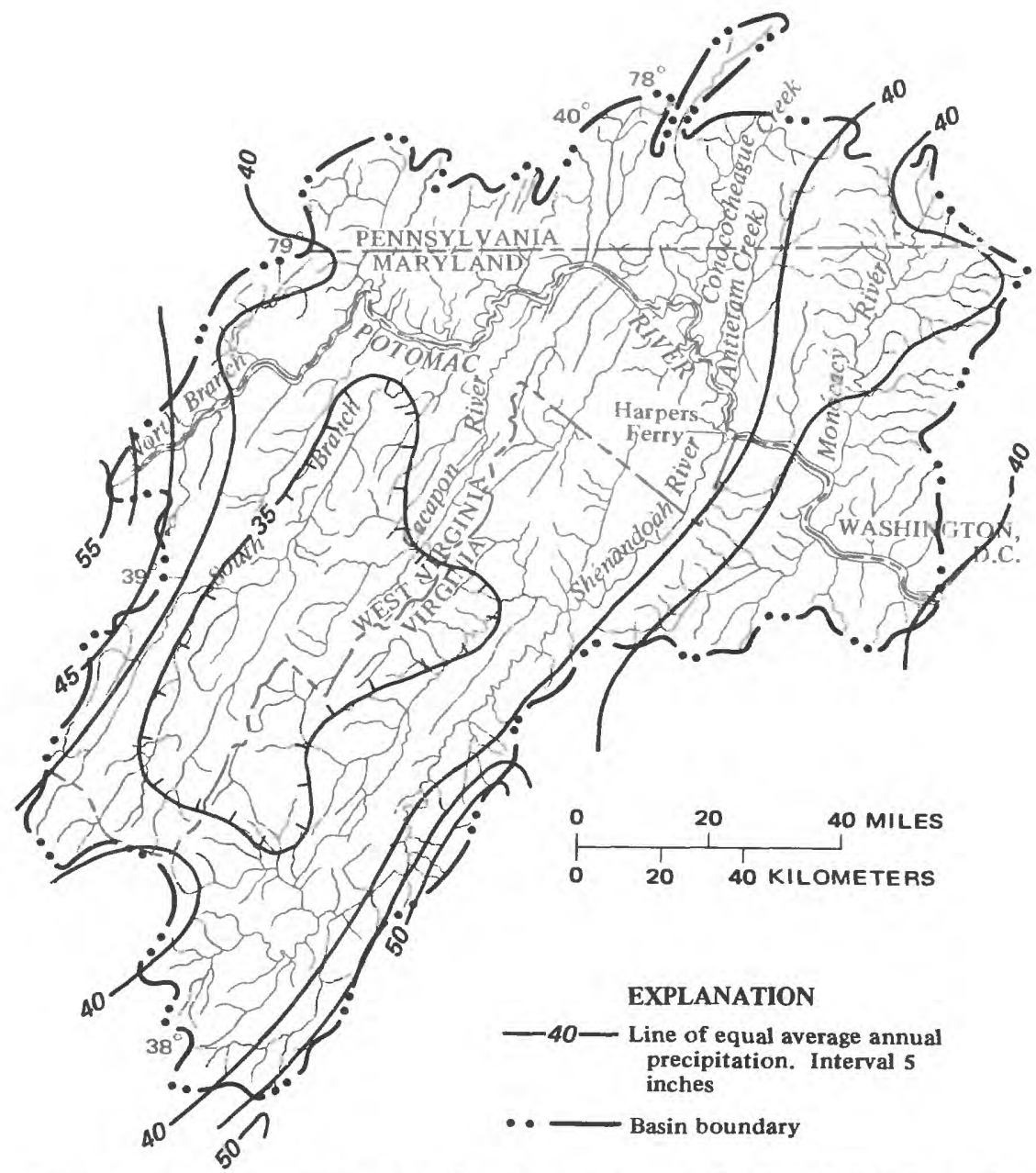

Figure 3.-Average annual precipitation (by water years), October 1947 to September 1967. Data from U.S. Weather Bureau (1947-65) and U.S. Environmental Data Service (1966-67).

Southeast of this area the annual precipitation increases to a maximum of about 50 inches on the Blue Ridge along the southeast edge of the basin and 40 to 45 inches on the Blue Ridge within the basin. Throughout most of the Piedmont the annual precipitation ranges from 38 to 40 inches.

During individual years the regional pattern of precipitation broadly resembles the patterns of the 20 -year average precipitation, but the total precipitation received at a locality during any one year may differ markedly from the long-term average. For example, study of records 
from 15 representative localities shows that during about one-third of the period ( 7 years) the average departure from the 20 -year local mean was 21 percent.

Analysis of a larger map, from which figure 3 was prepared, shows that the annual precipitation during 1947-67, averaged for the entire basin, was 37.9 inches. During this same period, the average annual streamflow leaving the upper Potomac River basin at its lower end was 12.7 inches, or 33 percent of the precipitation. Assuming underground outflow and changes in ground-water and soil-moisture storage to have been negligible, we conclude that 67 percent of the water supply received as precipitation was removed from the basin by evapotranspiration.

\section{TEMPERATURE AND EVAPOTRANSPIRATION}

Air temperature and its seasonal fluctuations are important in their hydrologic effects because they determine the form of the precipitation received by a region, affect the magnitude of evapotranspiration, and influence the timing and amount of ground-water recharge. The climate of the upper Potomac River basin is characterized by moderate temperature (table 1). Much of the winter precipitation is snow, but cold periods during the winter are interruppted by periods of warmer weather, and even in higher country the ground is not frozen continuously through a large part of the winter. Snowmelt and winter rain provide high runoff and the larger part of the year's ground-water recharge. Both recharge and runoff are greatly diminished in summer, when the air temperature is much higher and evapotranspiration is relatively more effective. The resulting annual regime of streamflow is a simple pluvial oceanic type (Pardé, 1955, p. 84-87; Ward, 1967, p. $350-351$ ), characterized by a single period of above-average discharge each year in winter and spring and by one of below-average discharge in summer and autumn.

T ABLE 1.-Average temperature at representative localities in the upper Potomac River basin

\begin{tabular}{|c|c|c|c|c|c|c|}
\hline \multirow{3}{*}{ Station } & \multicolumn{6}{|c|}{ Average temperature $^{1}$} \\
\hline & \multicolumn{2}{|c|}{ Annual } & \multicolumn{2}{|c|}{ January } & \multicolumn{2}{|c|}{ July } \\
\hline & ${ }^{\circ} \mathrm{F}$ & ${ }^{\circ} \mathrm{C}$ & ${ }^{\circ} \mathrm{F}$ & ${ }^{\circ} \mathrm{C}$ & ${ }^{\circ} \mathrm{F}$ & ${ }^{\circ} \mathrm{C}$ \\
\hline $\begin{array}{l}\text { Bayard, Grant County, } \\
\text { W. Va ..................... } \\
\text { Petersburg, Grant County }\end{array}$ & 47.4 & 8.6 & 29.1 & -1.6 & 66.9 & 19.4 \\
\hline $\begin{array}{l}\text { Petersburg, Grant County, } \\
\text { W. Va -................. } \\
\text { Mount Weather, Loudoun }\end{array}$ & 54.1 & 12.3 & 34.1 & 1.2 & 74.1 & 23.4 \\
\hline 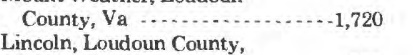 & 51.2 & 10.7 & 30.4 & -.9 & 72.5 & 22.5 \\
\hline Va $\ldots \ldots \ldots$ & 56.2 & 13.4 & 35.7 & 2.0 & 77.4 & 25.2 \\
\hline
\end{tabular}

I 30-year average (normal value) from U.S. Environmental Data Service (1968). 
Figure 4 illustrates the effect of evapotranspiration on ground water and streamflow. This graph is from a discussion of evapotranspiration and soil moisture by Thornthwaite and Mather (1955); it represents conditions at Seabrook, N.J., which are similar to those in the Potomac River basin. The graph shows that, whereas precipitation is fairly evenly distributed throughout the year, evapotranspiration is negligible in winter but large in summer.

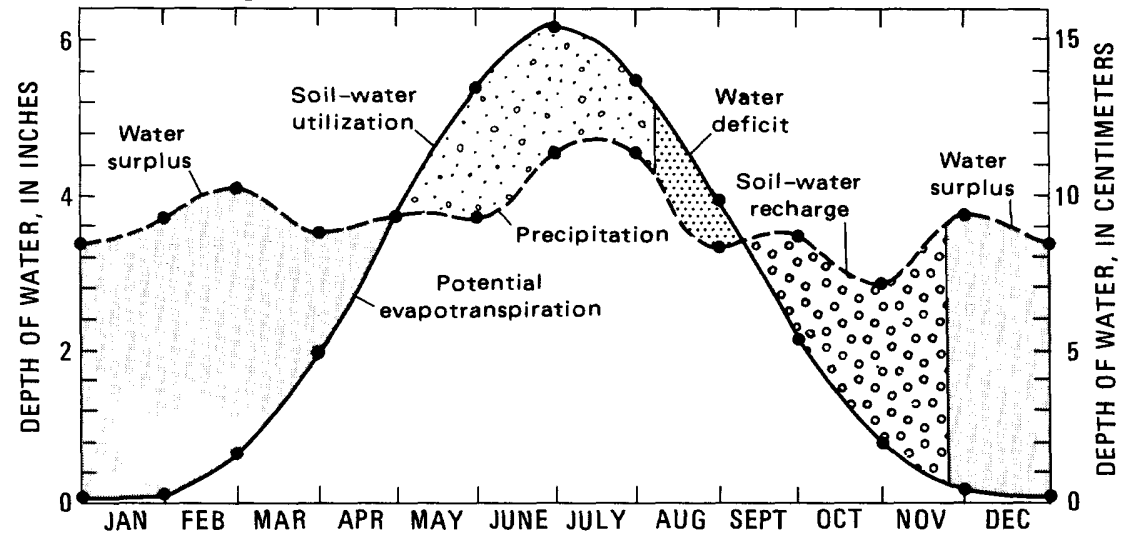

F IGURE 4.-Annual precipitation and potential evapotranspiration at Seabrook, N.J.

From Thornthwaite and Mather (1955).

Water that falls on the land surface is disposed in three ways. (1) Part evaporates from the land surface (that is, from soil, vegetation, and impervious surfaces). (2) Part infiltrates the soil, to be transpired by plants or held temporarily by the soil; any excess beyond the amount the soil can hold percolates downward toward the ground-water reservoir. (3) Part runs off the land surface or flows through near-surface material to streams.

Figure 4 shows that during the cold season (December-April) more water enters the soil than can be removed by evapotranspiration. A large part of this water goes to ground-water recharge. During the warm season (May-September) both transpiration by plants and evaporation occur; for a time, water stored in the soil makes up the difference between precipitation and potential evapotranspiration, but during the late summer the moisture content of the soil is less than field capacity. During the summer generally, and especially during periods of soilwater deficit, ground-water recharge is much less than in winter. Finally, during autumn the temperature is lower, and use of water by plants declines sharply; much of the rain goes into recharge of soil moisture. The general form of the relationships shown in figure 4 holds true for much of the eastern United States; differences in latitude (that is, in temperature and in duration of daylight) and precipitation cause differences in detail. 


\section{RUNOFF}

Runoff is precipitation that is residual after evapotranspiration. It consists of direct runoff, which occurs rather quickly after a rain or the melting of snow, and of base runoff, which is sustained flow that continues after direct runoff has ceased.Direct runoff consists of water that has moved across the land surface to the stream channels and of water that has reached them by flowing through the soil as ephemeral perched ground water. Base runoff is chiefly ground-water runoff from the main zone of saturation.

The interplay of fairly regular precipitation and seasonally changing evapotranspiration produces the annual pattern or runoff shown in figure $5 \mathrm{~A}$. A sweeping curve (dashed line), high in winter and spring and low in late summer and autumn, represents the yearly hydrograph of base runoff. Superposed on it are flood peaks, which, with peaks in ground-water recharge, result from storms or groups of storms. During winter, relatively large recharge leads to increase in ground-water storage. During summer, with lesser recharge but continuing discharge, ground-water storage becomes progressively depleted. The decreasing rate of ground-water discharge associated with the depletion of storage sustains dry-weather streamflow at progressively lower levels until recharge and ground-water runoff increase again during the following winter. (Agreement of the seasonal trend of streamflow with the trend of potential evapotranspiration is even more striking than may be apparent in figs. 4 and $5 A$. Thus, sustained streamflow, as shown on the logarithmic scale in fig. $5 A$, is about five times as great in winter and spring as in late summer.)

Base runoff can be observed directly in the stream hydrograph (solid line in fig. $5 \mathrm{~A}$ ), as the total streamflow, only during the long rainless periods. It must be estimated in the remainder of the hydrograph. In this investigation we estimated base runoff by hydrograph separation, a division of the hydrograph that distinguishes the components of the subsurface-surface flow system. Numerous methods of hydrograph separation have been used, all of them somewhat aribtrary and subjective. We followed a graphical procedure based on use of a curve showing base-runoff recession (Horton, 1933, p. 449; Snyder, 1939, p. 728-730; Grundy, 1951, p. 215-216; Am. Soc. Civil Engineers, 1949, p. 72-73; Trainer, 1969a). The resulting base-runoff hydrograph (dashed line in fig. $5 A$ ) separates the total hydrograph into its two components, base runoff (below) and direct runoff (above).

\section{HYDROLOGIC CHARACTERISTICS OF THE ROCKS}

The upper Potomac River basin is underlain by consolidated rocks which are mantled generally by weathered material (soil and regolith) and locally by stream deposits. Joints are the principal openings that 
$\dot{\theta} \rightarrow \vec{\omega}$

Dे

घ 1

象必.

卷

का

过实

$\sum \dot{\mathrm{a}}$
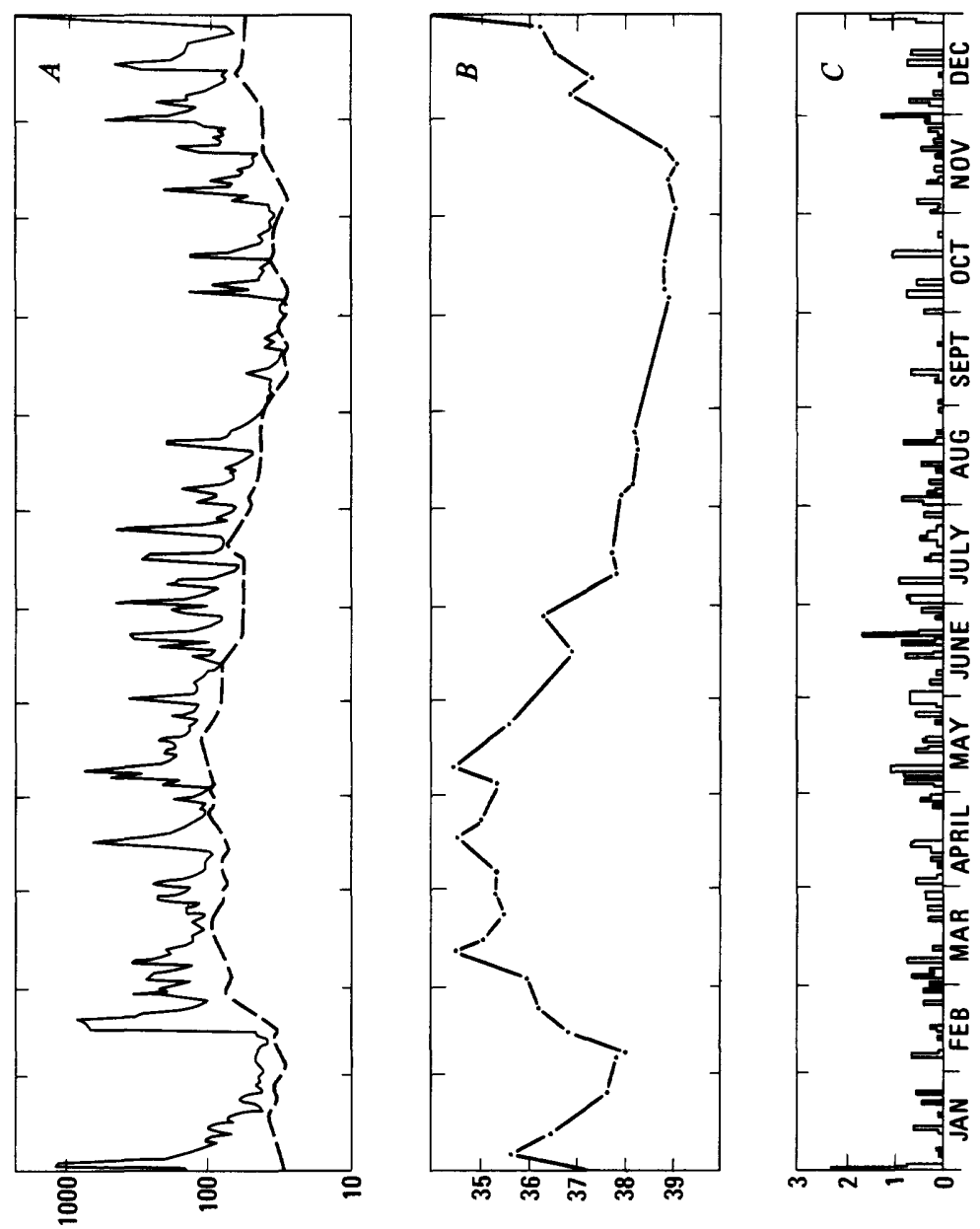

की 응

它家 更 ㄴํํ ชิ

क

$+\vec{B}$

놀

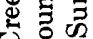

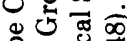
음

An 0

品通总

ลิ

它品

우의

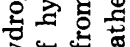

空艺

\

क्षे

至要

๙2 4 क

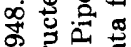

क $\sum_{\infty}$

$\rightarrow$ क

ญ

. .9.

胥

可芯

흉 뭉

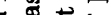
营范范 के

ธิ สิ 要 1 苛 훙요 造 过

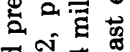
영ํㅀ웛 
store and transmit water in the consolidated rocks. The volume of these openings is small-probably at few places is it more than a few percent of the volume of the rock mass. The granular deposits store and transmit water in intergrain pores, which, although small, make up a larger part of the total air space in these deposits.

The water-bearing properties of a mass of rock are determined both by the fractures in the hard rock and by the mantle of unconsolidated material that covers it. Where the unconsolidated material is thick, there is more storage space than where it is thin or absent. Where the fractures have been widened by weathering, they store more water and transmit it more readily than where they are unmodified. For these reasons there are large differences in the waterbearing capacity of the ground in different parts of the upper Potomac River basin.

The Appalachian Plateaus and much of the western part of the Valley and Ridge province are underlain by sandstone and shale which bear a thin cover of soil and weathered rock. The shale and most of the sandstone have low intergrain permeability, and the storage and transmissive capacities of the rock depend on fractures. In carbonate rock, which underlies much of the Appalachian Valley and occurs in several smaller areas farther west in the Valley and Ridge province, the cover of weathered material is thicker, and some fractures have been widened by solution. The carbonate rock, therefore, stores more water and transmits it more readily than the fractured sandstone and shale. Crystalline rock in the mountainous part of the Blue Ridge, like the sandstone and shale to the west, stores water and transmits it through relatively unmodified fractures. In the eastern part of the Blue Ridge province and in the Piedmont, the fractured bedrock (crystalline rock, sandstone, and shale) is covered by thick regolith, commonly several feet to several tens of feet thick, which provides storage space for water.

The water-transmitting ability and storage capacity of the rock are described in terms of two hydraulic parameters-transmissivity and the storage coefficient. Transmissivity is the rate at which water is transmitted through a unit width of the full thickness of an aquifer, under unit hydraulic gradient and at the prevailing kinematic viscosity of the water. It is a ratio, length squared to time, and in reports of the Geological Survey is expressed in feet squared per day. The storage co fficient is the volume of water released from or taken into storage in an aquifer, per unit surface area of aquifer per unit change in head. It is a dimensionless unit.

Several kinds of data provide estimates of one or both hydraulic parameters for aquifers in the upper Potomac River basin: pumping tests in wells; water-table fluctuations in wells, as related to base runoff; the recession of water levels in wells; the water-table gradient over part of a tributary basin; and base-runoff recession in the river hydrograph for a tributary basin. Estimates made by using these 
various sources differ somewhat from one another but are broadly consistent when considered together. There are several reasons for the differences in results of the various analyses: field conditions meet the assumptions required for each analysis in different degree at different places; data used in the analyses differ in reliability; and different regions of aquifer were examined in each analysis.

The following sections of this part of the report summarize data on the hydraulic parameters of the aquifers and then consider estimates of representative values for the aquifer characteristics, as determined from the various kinds of data.

\section{ESTIMATES BASED ON PUMPING TESTS}

Three types of pumping tests have been made in the upper Potomac River basin. Most of these tests were made in earlier investigations. In the first type of test, water is pumped from a well under controlled conditions, and decline of the ground-water level is observed in one or more wells nearby. Analysis of data from this type of test permits determination of the transmissivity and the storage coefficient. In the second type, also a controlled test, no observation well is used; drawdown of water level is measured in the pumped well, and only transmissivity is normally computed. The third type is the driller's completion, or acceptance, test; it can be used to estimate transmissivity, but with much less reliability than the other tests.

The fractured rocks that constitute the principal aquifers in the basin are of diverse lithology and in large part layered; as a result, their hydraulic properties cover a wide range of values whose distribution in space is strongly directional. Thus, the rocks depart substantially from the isotropy and homogeneity assumed in the statement of the nonequilibrium formula by Theis (1935). The results of pumping tests in these fractured rocks must, therefore, be used cautiously with respect to both (1) the validity of use of the analysis and (2) the degree to which the results are representative of the aquifers.

The nonequilibrium formula derived by Theis (1935) is based on the following assumptions: (1) The aquifer is homogeneous and isotropic; (2) it has infinite areal extent; (3) its transmissivity is constant at all times and places; (4) the well penetrates and receives water from the entire saturated part of the aquifer; (5) the well has an infinitesimal diameter; and (6) water removed from storage is discharged instantaneously with decline in head.

Obviously, the fractured rocks that make up most of the aquifers in the upper Potomac River basin do not conform to these idealized assumptions. The aquifers are not isotropic, nor are they homogeneous except perhaps where a large volume of rock is considered. The assumption of infinite areal extent is probably met, with respect to individual wells pumped for short periods of time. Transmissivity seems to range 
between rather narrow limits, even though it is not constant at all times and places. Very few wells penetrate and receive water from the entire saturated thickness of the aquifer, but most of the more productive wells penetrate and receive their water from the major productive zones in the aquifer. The assumption that the well has an infinitesimal (that is, reasonably small) diameter is satisfied. The final assumption, that water removed from storage is discharged instantaneously with decline in head, is met only in part, because the water commonly occurs under water-table conditions.

\section{CONTROLLED PUMPING TESTS}

Table 2 summarizes the results of published aquifer tests made using at least one observation well (Meyer and Beall, 1958; Slaughter and Darling, 1962). These tests represent the range of rock types from the crystalline rocks of the Appalachian Plateaus in Maryland. The tests ranged in length from 1 hour to 215 hours; most of them exceeded 8 hours in length.

Table 3 is a summary of transmissivity values from published singlewell aquifer tests in the upper Potomac River basin (Meyer and Beall, 1958; Slaughter and Darling, 1962) and from tests in the files of the Geological Survey. The tests represent most of the rock types in the basin. Individual tests lasted from less than 1 to more than 2,100 hours; most of them lasted 4 hours or longer.

T ABLE 2.-Multiple-well aquifer tests in Maryland

\begin{tabular}{|c|c|c|c|c|c|}
\hline Formation & $\begin{array}{l}\text { Number } \\
\text { of wells }\end{array}$ & $\begin{array}{l}\text { Transmissivity } \\
\left(\mathrm{ft}^{2} / \mathrm{d}\right)\end{array}$ & $\begin{array}{l}\text { Coefficient } \\
\text { of storage }\end{array}$ & $\begin{array}{l}\text { Pumping } \\
\text { time } \\
\text { (hours) }\end{array}$ & $\begin{array}{l}\text { Source of } \\
\text { data }\end{array}$ \\
\hline Wakefield Marble & 2 & 6,952 & 0.004 & 1 & $\begin{array}{l}\text { Meyer and } \\
\text { Beall (1958). }\end{array}$ \\
\hline Frederick Limestone $\ldots \ldots \ldots$ & 6 & 57 & .00002 & 48 & Do. \\
\hline Marburg Schist $\ldots \ldots$ & 6 & 976 & .02 & 48 & Do. \\
\hline Wissahickon Formation ........ & 10 & 668 & .03 & 107 & Do. \\
\hline New Oxford Formation . . . . . . . & 6 & 668 & .001 & $2-$ & Do. \\
\hline Catoctin Metabasalt $\ldots \ldots \ldots$. & 2 & 909 & .021 & $3.5-$ & Do. \\
\hline Do $\ldots$ & 2 & 588 & .004 & $40+$ & $\begin{array}{l}\text { Slaughter } \\
\text { and Darling } \\
\text { (1962). }\end{array}$ \\
\hline Do. $\ldots \ldots \ldots$ & 2 & 454 & .002 & $40+$ & Do. \\
\hline Rockdale Run Formation . . . . . - & 2 & 16,980 & .14 & 4 & Do. \\
\hline Stonehenge Limestone & 2 & 26,740 & .018 & 9 & Do. \\
\hline Wills Creek Shale $. . . \ldots . . . .$. & 2 & 2,000 & .008 & 215 & Do. \\
\hline Do $\ldots \ldots \ldots$ & 2 & 1,760 & .010 & 215 & Do. \\
\hline $\begin{array}{l}\text { Helderberg and Tonoloway } \\
\text { Limestones. }\end{array}$ & 2 & 1,740 & .04 & $30+$ & Do. \\
\hline Pocono Sandstone & 2 & 210 & .0042 & 3 & Do. \\
\hline Do. & 2 & 174 & .0006 & 3 & Do. \\
\hline
\end{tabular}

\section{ACCEPTANCE TESTS}

In contrast with the relatively small number of controlled aquifer tests available, many well-completion, or acceptance, tests have been made by well drillers. The large number of these tests and the fact that 
T $\mathrm{ABLE}$ 3.-Single-well aquifer tests

\begin{tabular}{|c|c|c|c|c|}
\hline Formation or rock type & $\begin{array}{l}\text { Transmissivity } \\
\left(\mathrm{ft}^{2} / \mathrm{d}\right)\end{array}$ & $\begin{array}{l}\text { Pumping } \\
\text { time } \\
\text { (hours) }\end{array}$ & Remarks & $\begin{array}{l}\text { Source of } \\
\text { data }\end{array}$ \\
\hline Aporhyolite $\ldots$ & 290 & 24 & n... & $\begin{array}{l}\text { Meyer and } \\
\text { Beall }(1958) .\end{array}$ \\
\hline Catoctin Metabasalt $\ldots \ldots \ldots$. & 430 & $48+$ & $\begin{array}{l}\text { Water levels in } \\
\text { observation wells } \\
\text { rose during test. }\end{array}$ & $\begin{array}{l}\text { Slaughter } \\
\text { and Darling } \\
\text { (1962). }\end{array}$ \\
\hline Harpers Formation $\ldots \ldots \ldots$ & 70 & $1+$ & (n) & Do. \\
\hline Martinsburg Shale . ............. & 30 & 3 & $\begin{array}{l}\text { May not be represent- } \\
\text { ative of this rock. }\end{array}$ & $\begin{array}{l}\text { Do. } \\
\text { Do. }\end{array}$ \\
\hline Do $\ldots . . . . . . . . . . . . .$. & 10 & .5 & $\ldots \ldots \ldots$ do $\ldots . . . . . .$. & Do. \\
\hline Rockdale Run Formation ........ & 6 & .5 & do $\ldots . . .6$. & Do. \\
\hline 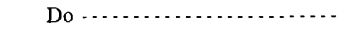 & 1 & $1+$ & $\ldots \ldots$ do $\ldots . . .6$. & Do. \\
\hline Do $\ldots \ldots \ldots \ldots$ & 19,000 & 4 & 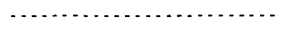 & Do. \\
\hline Conococheaque Limestone . . . . . . - & 2,500 & 28 & 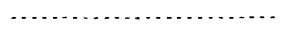 & Do. \\
\hline Do $\ldots \ldots \ldots$ & 290 & 28 & (n. & Do. \\
\hline Tomstown Dolomite ........... & 5 & $10+$ & (n. & Do. \\
\hline Do & 580 & $48+$ & $\begin{array}{l}\text { Transmissivity was } \\
2,440 \mathrm{ft}^{2} / \mathrm{d} \text { early } \\
\text { in test. }\end{array}$ & Do. \\
\hline Romney Shale $\ldots \ldots \ldots \ldots$ & 320 & $24+$ & (n. & Do. \\
\hline Do $\ldots \ldots \ldots$ & 9 & $3+$ & & Do. \\
\hline Do $\ldots \ldots \ldots$ & 3 & $2+$ & (n. & Do. \\
\hline Wills Creek Shale $\ldots . . . . . . .$. & 9 & .5 & 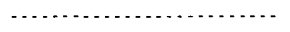 & Do. \\
\hline Do & 4 & $.5-$ & 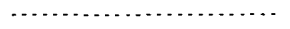 & Do. \\
\hline Do $\ldots \ldots \ldots$ & 45 & 1 & n. & Do. \\
\hline Hampshire Formation . . . . . . . . & 71 & $2-$ & 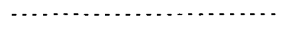 & Do. \\
\hline Jennings Formation......... & 130 & $8+$ & 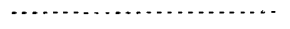 & Do. \\
\hline Do $\ldots \ldots \ldots \ldots$ & 170 & 6 & 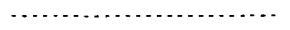 & Do. \\
\hline $\begin{array}{l}\text { Oriskany and Romney } \\
\text { Formations. }\end{array}$ & 1,900 & $8-$ & (n) & Do. \\
\hline $\begin{array}{l}\text { Rose Hill and Juniata } \\
\text { Formations. }\end{array}$ & 160 & 16 & 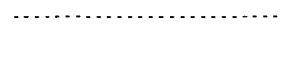 & Do. \\
\hline Conemaugh Formation ........... & 1,400 & 2,160 & (n. & Do. \\
\hline Do & 820 & 576 & 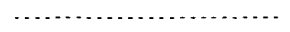 & Do. \\
\hline $\begin{array}{l}\text { Pottsville, Allegheny, and } \\
\text { Mauch Chunk Formations. }\end{array}$ & 60 & 24 & n. & Do. \\
\hline Pocono Sandstone $\ldots \ldots \ldots \ldots \ldots$ & 130 & 3 & ( & Do. \\
\hline Tomstown Dolomite & 1,700 & 11 & (n) & Nutter \\
\hline Newark Group (conglomerate) ${ }^{1} \ldots$. & 2,000 & 8.5 & Depth $120 \mathrm{ft}$ & Files of \\
\hline Do $\ldots \ldots \ldots \ldots \ldots \ldots$ & 2,300 & $5+$ & Depth $195 \mathrm{ft}$ & U.S.G.S., \\
\hline Do $\ldots \ldots \ldots$ & 2,500 & 4.5 & Depth $350 \mathrm{ft}$ & Reston. Va. \\
\hline
\end{tabular}

${ }^{1}$ Three tests in one well.

they represent most of the rock types that constitute the principal aquifers in the basin make them a potentially useful source of data, provided allowance can be made for lack of control in the testing. The principal sources of uncertainty in the interpretation of data from these tests are related to the character of the wells and to the character of the tests themselves.

Most of these wells were drilled for domestic or farm use. These uses required only a small quantity of water (a few gallons per minute) from most individual wells, and drilling was commonly stopped after a satisfactory yield was attained. Where a well was drilled deep to obtain this yield, or where a well failed to obtain it, the recorded yield is likely to be representative of the water-bearing characteristics of the rock at that place. But where a well was drilled to a relatively shallow depth to obtain the water needed, considerably more water may be available at 
greater depth, and the well, therefore, does not truly reflect the quantity of ground water available there. The degree to which low well yields are representative of the aquifers is complicated where wells were not cleaned (developed) adequately after the drilling to remove mud and rock chips, which clog some of the fractures in the walls of the wells. We believe that inadequate well development has affected yields in many of the acceptance tests.

Most of the acceptance tests were made by pumping water with a bailer on a cable-tool drill or with compressed air, where an airpercussion drill was used. Measurement of water level during pumping by these methods is difficult, and reported pumping levels must be considered as approximate. The duration of pumping ranged from $1 / 2$ to 8 hours or longer, and, hence, many of the tests are not comparable with one another because reported final water levels represent different periods of water-level decline. The justification for this assumption is that a large part of the drawdown of water level during pumping occurs during the early part of pumping; we have assumed for this analysis, however, that the values are approximately comparable despite differences in length of test.

The test data from a given well provide the specific capacity of that well, expressed as gallons per minute per foot of drawdown. Using a chart which relates well diameter, specific capacity, and the transmissivity and storage coefficient (Theis and others, 1963, p. 339), we estimated transmissivity on the basis of specific capacity. To make this estimate, we assumed a single value for the storage coefficient of 0.02 . Figure 6 illustrates the distribution of these inferred values of transmissivity in several representative types of rock. Transmissivity is plotted against depth of penetration of saturated rock; it is also plotted against distance of the well from the nearest stream for several rock types.

Figure 6 clearly shows that the average transmissivity, as determined from these data, is relatively low. In several plots of transmissivity against depth of penetration, the low values are spread over a wide range of depth. As noted earlier, the deeper wells were probably drilled deep in an effort to increase a small yield. We infer that a well already drilled to a depth of perhaps 100 feet below the level of the water table without penetrating significant water-bearing fractures is unlikely to penetrate such openings at even greater depth. On the other hand, some wells of higher yield and lesser depth of penetration are in more favorable locations and would probably have had appreciably higher yields if they had been drilled deeper. The dashed line in figures $6 A-E$ suggests a rough definition of the maximum transmissivity to be expected in most of the noncarbonate rocks. If a depth of penetration of 100 feet is arbitrarily taken as the depth within which most of the water-bearing fractures occur, the probable maximum transmissivity 
for these noncarbonate rocks ranges from 200 to $350 \mathrm{ft}^{2} / \mathrm{d}$; the median observed transmissivity ranged from 40 to $90 \mathrm{ft}^{2} / \mathrm{d}$.

Data from wells in carbonate rock (fig. $6 F$ ) show a much greater range in transmissivity. Many low values are comparable with those in plots $A-E$, but there are more intermediate and high values than in those plots, and the median observed transmissivity of $140 \mathrm{ft}^{2} / \mathrm{d}$ is about twice that of the noncarbonate rocks. Examination of the geographic distribution of the wells of high transmissivity, in the carbonate rock, shows that two-thirds of the values above the dashed line in figure $6 F$ represent wells near streams.

The right-hand plot in figure $6 F$ illustrates the distribution of transmissivity values with respect to distance from well to stream. (This distance was measured on topographic maps at a scale of 1:24,000 along the inferred flowline-normal to the water-table contour lines-from the well to the nearest stream.) The higher values tend to lie near streams: about 60 percent of the values greater than the median lie within 1,000 feet of a stream. The right-hand plots in figures $6 \mathrm{~A}$ and $B$, on the other hand, show little relation between transmissivity and distance from stream in representative shale-sandstone and schistose rocks. The distribution of fractures in the carbonate rock is probably much like that in the noncarbonate rock; but some fractures in the carbonate rock have been widened by solution, and these fractures tend to form in the region of concentrated ground-water flow near the streams. A distribution of transmissivity values somewhat similar to that for carbonate rocks is found in the Martinsburg Shale (fig. 6G), which consists in part of calcareous shale and thin limestone beds. Thus, fracturedrock aquifers seem to form a continuous series, ranging from slightly permeable rock containing unmodified fractures to much more permeable rock in which the fractures have been widened by solution. Solution is almost entirely limited to carbonate rock and to other rock containing considerable calcareous material, and it is largely limited to these rocks near streams.

\section{ESTIMATES BASED ON FLUCTUATION OF THE WATER TABLE}

The gravity yield of an unconfined aquifer, computed over several to many months, is an approximation of the storage coefficient in the zone of water-table fluctuation. It is the ratio of change in ground-water storage in a given area to change in average ground-water stage in the same area. Change in storage is determined indirectly, from base runoff, as the net volume of ground water released from storage, or taken into storage, during a specified period of water-table fluctation. The winter recession curve of base runoff, which expresses the rate of natural ground-water discharge from the aquifer, is used to estimate the change in storage. Change in stage is measured in observation wells. 

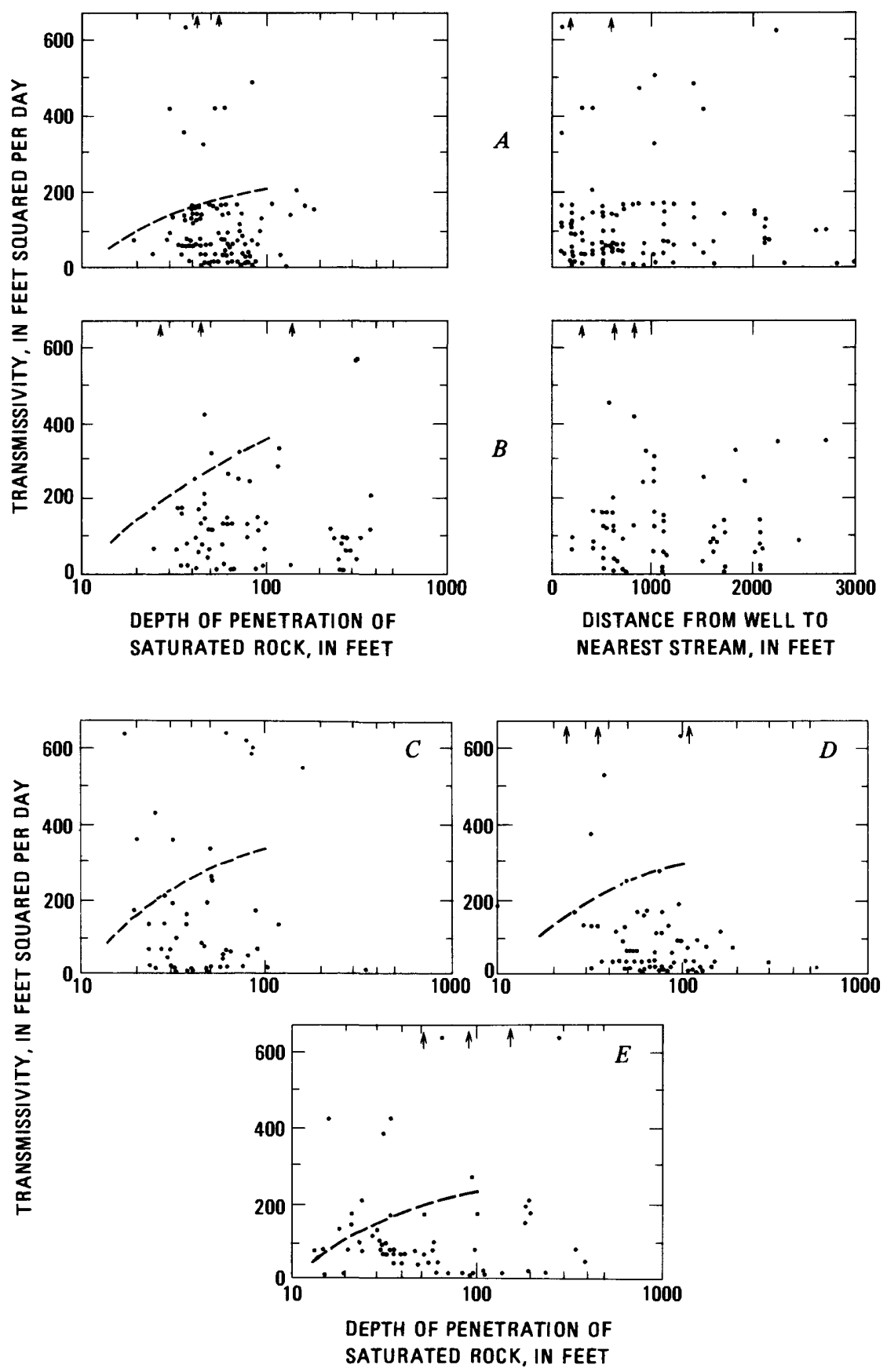

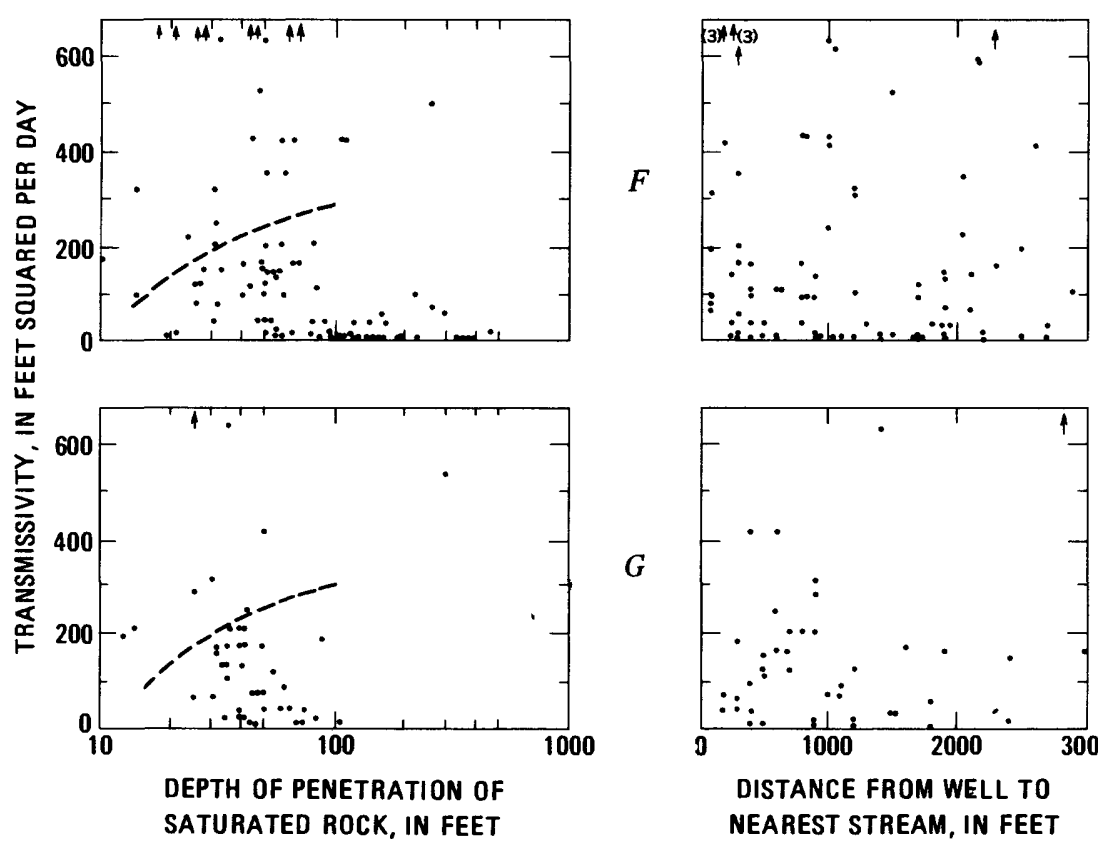

F IGURE 6.-Distribution of values of transmissivity with respect to depth of penetration of saturated rock by wells and with respect to distance from well to nearest stream. Arrow near upper margin indicates a value of transmissivity greater than about $650 \mathrm{ft}^{2} / \mathrm{d}$ (feet squared per day). Dashed line indicates suggested maximum transmissivity to be ecpected.

$A$, Wells in shale, siltstone, and sandstone: Romney Shale and Jennings Formation in Allegany and Washington Counties, Md.; data from Slaughter and Darling (1962, tables 40 and 42). Median transmissivity about $70 \mathrm{ft}^{2} / \mathrm{d}$.

$B$, Wells in schist: Wissahickon Formation in Montgomery and Carroll Counties, Md.; data from Dingman, Meyer, and Martin (1954, table 2) and Meyer and Beall (1958, table 25). Median transmissivity about $90 \mathrm{ft}^{2} / \mathrm{d}$.

$C$, Wells in sandstone and shale: Pocono Sandstone and Mauch Chunk, Pottsville, Allegheny, Conemaugh, and Monongahela Formations in Allegany and Garrett Counties, Md.; data from Slaughter and Darling (1962, table 40) and Amsden, Overbeck, and Martin (1954, table 20). Median transmissivity about $60 \mathrm{ft}^{2} / \mathrm{d}$.

$D$, Wells in sandstone: New Oxford Formation in Montgomery and Frederick Counties, Md.; data from Dingman, Meyer, and Martin (1954, table 2) and Meyer and Beall (1958, table 26). Median transmissivity about $40 \mathrm{ft}^{2} / \mathrm{d}$.

$E$, Wells in metabasalt: Catoctin Metabasalt in Frederick and Washington Counties, Md.; data from Meyer and Beall (1958, table 26) and Slaughter and Darling (1962, table 42). Merlian transmissivity about $70 \mathrm{ft}^{2} / \mathrm{d}$.

$F$, Wells in carbonate rock: Conococheague Limestone and Beekmantown Group in Washington County, Md.; data from Slaughter and Darling (1962, table 42). Median transmissivity about $140 \mathrm{ft}^{2} / \mathrm{d}$.

$G$, Wells in shale: Martinsburg Shale in Washington County, Md.; data from Slaughter and Darling (1962, table 42). Median transmissivity about $110 \mathrm{ft}^{2} / \mathrm{d}$. 
The following example, using a method described by Olmsted and Hely (1962, p. A16-A18) in a study in Pennsylvania, illustrates the computation of gravity yield.

Four observation wells were used to measure change in ground-water stage in the basin of the Monocacy River above Bridgeport, Md. The average change in stage in these four wells from March 26, 1968, to October 14, 1968, was -4.0 feet, or -48 inches. The base runoff of the river for each of these dates was determined by hydrograph separation. The area beneath the winter base-runoff recession curve, between the level of discharge for March 26 and that for October 14, was determined by summation to be $1,808 \mathrm{cfs}$ (cubic feet per second)-days. This total, which represents ground-water drainage without evapotranspiration, probably approximates the net change in ground-water storage over this period; it is equivalent to a layer of water 0.4 inch deep over the basin. The ratio $0.4: 48$, or 0.8 percent, is the gravity yield of the zone of water-table fluctuation, as estimated on the basis of water-level data from the four observation wells. The estimate is subject to error because of the small amount of evapotranspiration not accounted for by the winter recession curve, because the parts of the aquifer tapped by the observation wells may not be representative of the entire drainage basin, and because the estimate of change in storage depends on the use of hydrograph separation, which is a subjective procedure.

Table 4 summarizes values determined for the gravity yield of noncarbonate rocks in the upper Potomac River basin. We have not computed gravity yield for carbonate rock because base runoff and the slope of the winter recession curve have not been determined with sufficient precision for the carbonate rock.

With the exception of determinations for the first basin listed in table 4 (Abram Creek, which is in the Appalachian Plateaus province), the values for gravity yield fall into two groups. In fractured rock having thin regolith, the gravity yield averages about 0.5 percent; in fractured rock having thick regolith, it is about 1 percent.

Gravity yield is somewhat smaller than the storage coefficient if the dewatered part of the aquifer was not drained completely during the determination of gravity yield. However, where seasonal fluctations of the water table are used in the determination, gravity yield is probably as representative of the storage coefficient as are values for this coefficient determined from short pumping tests. The most serious question concerning the values in table 4 is the degree to which they represent the water-bearing materials: in several basins, only one or two observation wells were available - too few to represent the range in character of bedrock and regolith in these basins. However, the consistency of most of the values suggests that they are representative of the aquifers as viewed in the broad twofold classification used here.

We have not established an explanation for the relatively high gravity 
yield computed from data from the basin of Abram Creek. Possibly, the regolith there is thicker and sandier than in the other basins studied.

Values for gravity yield that we determined in the Piedmont province in Maryland and Virginia are only a seventh to a tenth the magnitude of values that Olmsted and Hely (1962, p. A17) obtained in the Piedmont in Pennsylvania. We attribute this difference in gravity yield to difference in the slopes of the recession curves-slopes for the Potomac basin are much steeper than that determined in the Pennsylvania study (Olmsted and Hely, 1962, p. A16).

\section{ESTIMATES BASED ON GROUND-WATER RECESSION}

Rorabaugh (1960) described a method of computing aquifer diffusivity $(T / S)$ from the slope of the curve showing recession of water level in a well, using an equation which indicates that after sufficient time has elapsed for the water-table profile to stabilize, water-level decline is exponential with time. The equation contains a series of terms, all but the first of which can be neglected for practical computation after stabilization has occurred. The abbreviated equation (Rorabaugh, 1960, p. 317) is

$$
T / S=0.933 \frac{a^{2} \log h_{1} / h_{2}}{t_{2}-t_{1}},
$$

where $T$ is aquifer transmissivity, $S$ is the storage coefficient, $a$ is the distance from the stream to the ground-water divide along a section which passes through the well, and $h_{1}$ and $h_{2}$ are the initial and final

TABLE 4.-Gravity yield for noncarbonate rocks

\begin{tabular}{|c|c|c|c|c|c|}
\hline \multirow[t]{2}{*}{ Station! } & \multirow[t]{2}{*}{ Tributary basin } & \multirow{2}{*}{$\begin{array}{l}\text { Number } \\
\text { of tests }\end{array}$} & \multirow{2}{*}{$\begin{array}{l}\text { Number } \\
\text { of wells }\end{array}$} & \multicolumn{2}{|c|}{$\begin{array}{l}\text { Gravity yield } \\
\text { (percent) }\end{array}$} \\
\hline & & & & Range & Average \\
\hline \multicolumn{6}{|c|}{ Fractured rock having thin regolith } \\
\hline 5953 & Abram Creek at Oakmont, W. Va $\ldots \ldots \ldots$ & 3 & 3 & $1.3-2.1$ & 1.6 \\
\hline 6045 & $\begin{array}{l}\text { Patterson Creek near Headsville, } \\
\text { W. Va. }\end{array}$ & 3 & 2 & $.2-.8$ & .4 \\
\hline 6085 & $\begin{array}{l}\text { South Branch Potomac River } \\
\text { near Springfield, W. Va. }{ }^{3}\end{array}$ & 1 & 7 & $\cdots \cdots$ & .3 \\
\hline 6355 & Passage Creek at Buckton, Va $\ldots \ldots \ldots \ldots$ & 4 & 1 & $.3-.7$ & .5 \\
\hline \multicolumn{6}{|c|}{ Fractured rock having thick regolith } \\
\hline 6390 & Monocacy River at Bridgeport, Md ......... & 4 & 5 & $0.6-0.8$ & 0.7 \\
\hline 6395 & Big Pipe Creek at Bruceville, Md............ & 12 & 2 & $.4-1.9$ & 1.2 \\
\hline 6440 & Goose Creek near Leesburg, Va $\ldots . . . . . . .$. & $5^{4}$ & 6 & $1.0-1.3$ & 1.1 \\
\hline 6450 & Seneca Creek at Dawsonville, Md .......... & 14 & 3 & $.1-1.6$ & .7 \\
\hline 6460 & $\begin{array}{l}\text { Difficult Run near Great Falls, } \\
\text { Va. }\end{array}$ & 7 & 1 & $.5-2.2$ & 1.4 \\
\hline
\end{tabular}

\footnotetext{
'Stream-gaging station, U.S. Geological Survey.

'Total number of wells used; not all wells were used in all tests.

'Streamflow data adjusted to represent the part of the tributary basin below gages near Petersburg (sta. 6065) and near Moorefield (sta. 6080). This part of the basin is underlain almost everywhere by tight sandstone and shale.
} 
water levels in the well, measured above stream level, at times $t_{1}$ and $t_{2}$, respectively. To facilitate computation, $h_{1}$ and $h_{2}$ are taken one log cycle apart, so $\log h_{1} / h_{2}$ equals unity.

Rorabaugh's model is based on the assumptions that the stream penetrates the full thickness of the aquifer, the aquifer is homogeneous and isotropic, and the observation well is on a profile that extends, straight in plan, from the ground-water divide to the stream. These assumptions seem to be met reasonably well in some parts of the upper Potomac River basin. The assumption of complete penetration is partly fulfilled, because in large parts of the basin the near-surface zone of relatively permeable rock probably does not extend far below the level of the streams. With respect to the character of the aquifers and the shapes of the water-table profiles, in much of the Piedmont region the water table is in the mantle of weathered rock material (regolith) throughout the year, and much of the flow of ground water is through this material. The porosity of the regolith is greater and is probably more uniform in space than that of the original unweathered rock. In such deposits, water-table profiles probably approach the idealized semiparabolic shape assumed for the model. In carbonate rock, on the other hand, the directional distribution of openings has been accentuated selectively by solution during ground-water flow, and in many places flow follows such circuitous paths that the flow conditions probably cannot be represented by simple idealized profiles. Relatively unmodified fractured rocks present conditions that are intermediate between these extremes. Accordingly, use of the method seems to be justified but requires caution.

Figure 7 illustrates several recession segments in ground-water hydrographs for well $\mathrm{Fr}-\mathrm{Cg} 1$, in Frederick County, Md. The shortdashed line fitted to the straight-line segment of the 1947 hydrograph shows the slope of the inferred average recession curve; the slope is -1 $\log$ cycle/945 days. Substitution of this slope and of 1,500 feet for $a$ in equation 1 yields a value of $2,200 \mathrm{ft}^{2} / \mathrm{d}$ for the aquifer diffusivity.

Diffusivity values determined by this method are listed in table 5 . The relative magnitudes of these values are probably generally consistent with the types of rocks represented. Transmissivity can be computed from diffusivity if the coefficient of storage is known or can be estimated. Average values for the coefficient of storage are probably 0.005 for fractured rock having thin regolith and 0.03 for carbonate rock. Use of these storage coefficients yields transmissivity values that range from 2 to $50 \mathrm{ft}^{2} / \mathrm{d}$ in the noncarbonate rocks and from 15 to $270 \mathrm{ft}^{2} / \mathrm{d}$ in the carbonate rocks.

\section{ESTIMATES BASED ON THE GRADIENT OF THE WATER TABLE}

Jacob (1943; see also Ferris and others, 1962, p. 130-132) gave an equation for a steady-state water-table profile that relates transmissivi- 


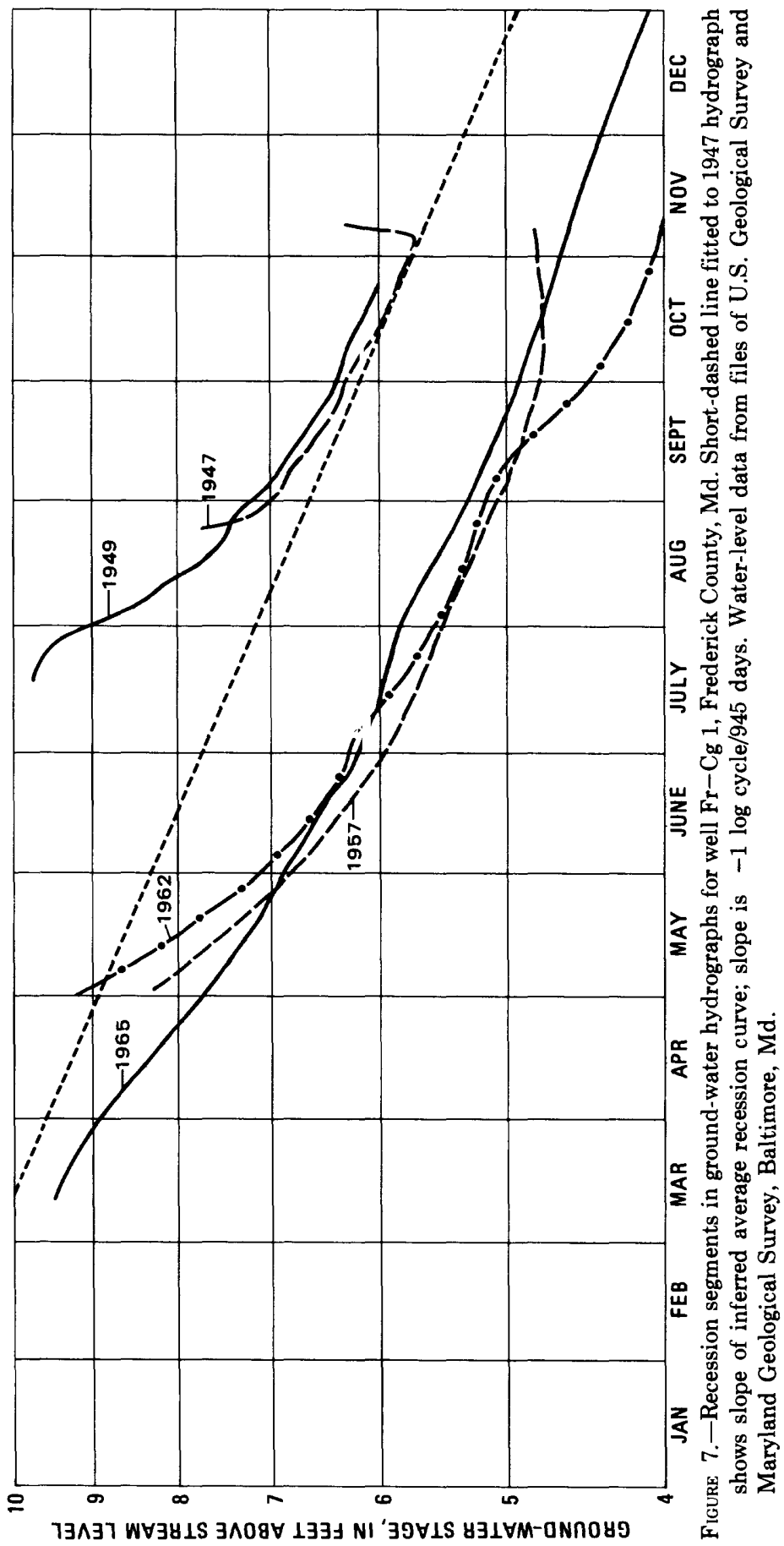


ty to the shape of the profile. The method assumes a stream that fully penetrates the aquifer, an aquifer that is homogeneous and isotropic, and recharge that is constant in time and space. As was noted in the preceding section, the assumption of complete penetration seems to be partly fulfilled. On the scale of a profile across a large part of a stream basin, we can consider the aquifer as approaching a homogeneous and isotropic character. Recharge obviously is not constant; but because our measurements of the altitude of the water table were made at different times in different wells, our water-table profiles must be considered as

TABLE 5.-Aquifer diffusivity estimated from recession of ground-water level in wells

\begin{tabular}{|c|c|c|c|}
\hline Well $^{1}$ & Location & Formation or rock type & $\begin{array}{l}\text { Diffusivity } \\
\left(\mathrm{ft}^{2} / \mathrm{d}\right)\end{array}$ \\
\hline \multicolumn{4}{|c|}{ Fractured rock having thin regolith } \\
\hline & $\begin{array}{l}\text { Elizabeth Furnace Recreation Area, } \\
\text { Shenandoah County, Va }\end{array}$ & Shale $\ldots \ldots \ldots . . .6$ & 750 \\
\hline$\ldots \ldots \ldots \ldots \ldots$ & $\begin{array}{l}\text { Near New Market, Shenandoah } \\
\text { County, Va }\end{array}$ & 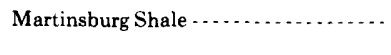 & 300 \\
\hline 391724 N0782358.1 & $\begin{array}{l}\text { Near Hanging Rock, Hampshire } \\
\text { County, W. Va. }\end{array}$ & Shale and sandstone & 1,400 \\
\hline 390234 N0784511.1 & Baker, Hardy County, W. Va & Shale $\ldots$. & 3,300 \\
\hline
\end{tabular}

\section{Fractured rock having thick regolith}

\begin{tabular}{|c|c|c|c|}
\hline $\mathrm{Fr}-\mathrm{Bd} 1$ & Thurmont, Frederick County, Md & Harpers Formation (phyllite). & 3,600 \\
\hline $\mathrm{Fr}-\mathrm{Cg} 1$ & Johnsville, Frederick County, Md & Ijamsville Phyllite $\ldots . . .$. & 2,200 \\
\hline Mont-Be 1 & Damascus, Montgomery County, Md & , do $\ldots \ldots$ & 4,800 \\
\hline $391247 \mathrm{~N} 0772032.1$ & Near Boyds, Montgomery County, Md. & 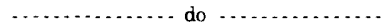 & 3,200 \\
\hline $391304 \mathrm{~N} 0772032.1$ & a do -1.0 & do $\cdots$ & 730 \\
\hline$F_{r}-F_{c} 1$ & Point of Rocks, Frederick County, Md & $\begin{array}{l}\text { New Oxford Formation } \\
\text { (limestone conglomerate). }\end{array}$ & 800 \\
\hline $390825 \mathrm{~N} 0774038.1$ & Purcellville, Loudoun County, Va. & Marshall Formation (gneiss). & 1,300 \\
\hline $390834 \mathrm{~N} 0774259.1$ & - & 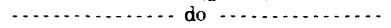 & 4,300 \\
\hline $390038 \mathrm{~N} 0774511.1$ & Near Middleburg, Loudoun County, Va. & Catoctin Metabasalt $\ldots \ldots \ldots \ldots \ldots \ldots$ & 2,300 \\
\hline 385818 N0774141.1 & do & Schistose rocks & 900 \\
\hline & Near Oatlands, Loudoun County, Va. & Diabase & 980 \\
\hline 385649 N0773217.1 & Arcola, Loudoun County, Va. & . & 610 \\
\hline
\end{tabular}

Carbonate rock

\begin{tabular}{|c|c|c|c|}
\hline $23-6-1$ & $\begin{array}{l}\text { Near Martinsburg, Berkeley } \\
\text { County, W. Va. }\end{array}$ & Chambersburg Limestone $\ldots \ldots \ldots \ldots$ & 3,300 \\
\hline & Near Berryville Clarke County, Va. & Beekmantown Group & 3,000 \\
\hline $390359 \mathrm{~N} 0781410.1$ & $\begin{array}{l}\text { Near Stephens City, Frederick } \\
\text { County, Va. }\end{array}$ & (n. & 580 \\
\hline $390402 \mathrm{~N} 0781755.1$ & $\begin{array}{l}\text { Near Middletown, Frederick } \\
\text { County, Va. }\end{array}$ & ................ do & 780 \\
\hline $382227 \mathrm{~N} 0784413.1$ & $\begin{array}{l}\text { McGaheysville, Rockingham } \\
\text { County, Va. }\end{array}$ & (............. do & 1,000 \\
\hline $382208 \mathrm{~N} 0784448.1$ & .................. do & and do & 3,800 \\
\hline 392428 N0782410.1 & $\begin{array}{l}\text { Bloomery Furnace, Hampshire } \\
\text { County, W. Va. }\end{array}$ & Tonoloway Limestone ....................... & 8,400 \\
\hline $390357 \mathrm{~N} 0783921.1$ & $\begin{array}{l}\text { Near Wardensville, Hardy } \\
\text { County, W. Va. }\end{array}$ & Helderberg Limestone............ & 2,700 \\
\hline $384359 \mathrm{~N} 0791438.1$ & $\begin{array}{l}\text { Near Franklin, Pendleton } \\
\text { County, W. Va. }\end{array}$ & Carbonate rock -. & 3,900 \\
\hline 384447 N0791357.1 & . & ............ do & 2,900 \\
\hline $384425 \mathrm{~N} 0791404.1$ & . & . do & 1,500 \\
\hline $383312 \mathrm{~N} 0792406.1$ & 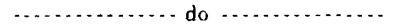 & no do & 9,100 \\
\hline
\end{tabular}

${ }^{1} \mathrm{Fr}$, well in Frederick County, Md.; data from Meyer and Beall (1958). Mont, well in Montgomery County, Md.; data fmm Dingman, Meyer, and Martin (1954). Data for well 23-6-1 from Bieber (1961). Data on other wells in files of U.S. Geological Survey. 
average profiles, and use of an average steady rate for the intermittent recharge is reasonable. Under steady-state conditions, the recharge would equal the base runoff, assuming no change in storage. Hence, the transmissivity can be estimated for part of a stream basin if the increment to base runoff within that part of the basin is known. We have used this approach to estimate the transmissivity of the aquifer in the Appalachian Valley.

A water-level contour map (pl. 1) was compiled for the lowland part of the Appalachian Valley. On the main stem of the Potomac River, this area extends from a point near the mouth of Back Creek to the vicinity of Harper's Ferry, below the mouth of the Shenandoah River. Principal streams in the mapped area are Conococheaque, Antietam, and Opequon Creeks and the Shenandoah River. The map was compiled on quadrangle maps at a scale of 1:62,500 and was later redrawn at a scale of $1: 250,000$.

The map is based on all available water-level data; the data were plotted without adjusting the measurements to a common date. The map thus contains inconsistencies due to random plotting with reference to time, but because the contour interval is 100 feet and the maximum range in water-level fluctuation in observation wells is about 20 feet, the map gives a reasonable picture of the shape of the water table. In areas where few or no data were available, the contours were sketched using the topography and streams as a guide as to form and altitude.

The pattern of contours on plate 1 shows that the ground-water reservoir in the lowland is drained by the principal tributary streams that flow down each side of the valley toward the Potomac River: the water table slopes toward these streams from the higher ground on either side of the valley and from a ground-water divide near the center of the lowland between the streams. The gradient of the water table is commonly gentler in areas underlain by carbonate rock than in areas underlain by crystalline rock or by shale; these lower gradients reflect the higher average permeability of the carbonate rock. Extensive areas where relief of the water table is very low identify areas where the average permeability can be expected to be highest. Such areas (pl. 1) include those between Hagerstown, Md., and Chambersburg, Pa.; between the Potomac River and Front Royal, in West Virginia and Virginia; and along the east and west sides of the southern Shenandoah Valley in Virginia.

Jacob (1943, p. 566) gave the equation of the steady-state water-table profile as

$$
h_{0}=\frac{a^{2} W}{2 T}\left(\frac{2 x}{a}-\frac{x^{2}}{a^{2}}\right),
$$


or

$$
\frac{T}{W}=\frac{a x}{h_{0}}-\frac{x^{2}}{2 h_{0}}
$$

where

$T=$ transmissivity,

$W=$ constant rate of recharge to water table,

$a=$ distance from stream to ground-water divide,

$x=$ distance from stream to observation well, and

$h_{0}=$ altitude of water table at observation well with respect to mean stream level at lower end of profile.

If $W$ is in inches per year, while $a, x$, and $h_{0}$ are in feet and $T$ is in $\mathrm{ft}^{2} / \mathrm{d}$, the equation can be rewritten as

$$
T=2.29\left(10^{-4}\right) W\left(\frac{a x}{h_{0}}-\frac{x^{2}}{2 h_{0}}\right) .
$$

If $x=a$, the equation reduces to

$$
T=2.29\left(10^{-4}\right) W \frac{a^{2}}{2 h_{0}}
$$

Equation 3 can be solved for $T$ if a value for $W$ is known or can be computed.

The following procedure was used to compute $W$. The difference in average daily base flow between successive gaging stations during 1953-57 (water years) was determined by hydrograph separation. The base runoff entering the stream in the reach between gages divided by the distance between the gages yields a value $\left(Q_{b}\right)$ for the total amount of base runoff entering the stream per unit length from both sides. Where the rocks making up the aquifers along a stream are similar on both sides, the amount of water entering from each side was assumed to be the same, and $Q_{\mathrm{b}}$ was divided by two to obtain $q_{\mathrm{b}}$, the base runoff from the region of a profile. $W$ can then be computed using the following equation:

$$
W=4.22\left(10^{5}\right) \frac{q_{b}}{a}
$$

Where the aquifers differ on opposite sides of the stream, an adjustment was made on the basis of the gradients of profiles on the two sides. 
Table 6 gives estimates of $T$ determined using computed $W$ values for selected water-table profiles; plate 1 shows the locations of these profiles. The $T$ values estimated in this manner, by using equation 3 , compare fairly well with those determined from pumping-test data. This agreement leads us to believe that use of the gradient method is justified in the Appalachian Valley, despite the strong directional properties of the rocks.

A check of the $W$ values was made in the carbonate rocks by measuring the difference in altitude between the stream level and the water table at the ground-water divide or at the contact between rock types (for example, at the contact of carbonate rocks with crystalline rocks). The distance from the stream to the divide or contact was also measured. The difference in altitude, $h_{0}$, was plotted against the distance squared, $a^{2}$, and coordinates of a point on this line were substituted into the equation

$$
W=\frac{2 h_{0} T}{a^{2}} .
$$

The equation was then solved for $W$ by substituting values of $T$, based on pumping-test data. Average base runoff for the nongrowing seasons during 1953-57 was compiled from hydrograph separations. Values of $W$ computed by this method range from about 1 in. to about $23 \mathrm{in}$./yr, or about the same range as that shown in table 6. (It is important to study data from the nongrowing season in order to avoid complications introduced by evapotranspiriation.)

\section{ESTIMATES BASED ON BASE-RUNOFF RECESSION}

Equation 1, the equation applied by Rorabaugh (1960) to study waterlevel recession in wells, can also be used in analysis of the flow of water, after a decline in river stage, from an unconfined aquifer into a river that is hydraulically connected with it. An abbreviated form of the equation (Rorabaugh and Simons, 1966, p. 12), in which stream discharge (base runoff) is used instead of ground-water head, is

$$
\frac{T}{a^{2} S}=\frac{0.933}{\Delta t / \text { cycle }},
$$

where $T$ is aquifer transmissivity, $S$ is the storage coefficient, $a$ is the distance from the stream to the hydologic divide, and $\Delta t$ is the time required for discharge to decline through one log cycle.

Where this equation can be used, it provides a means of estimating the average (basin) value for aquifer transmissivity on the basis of streamflow data. Three factors that complicate the interpretation deserve preliminary comment: (1) the brevity of most recession 


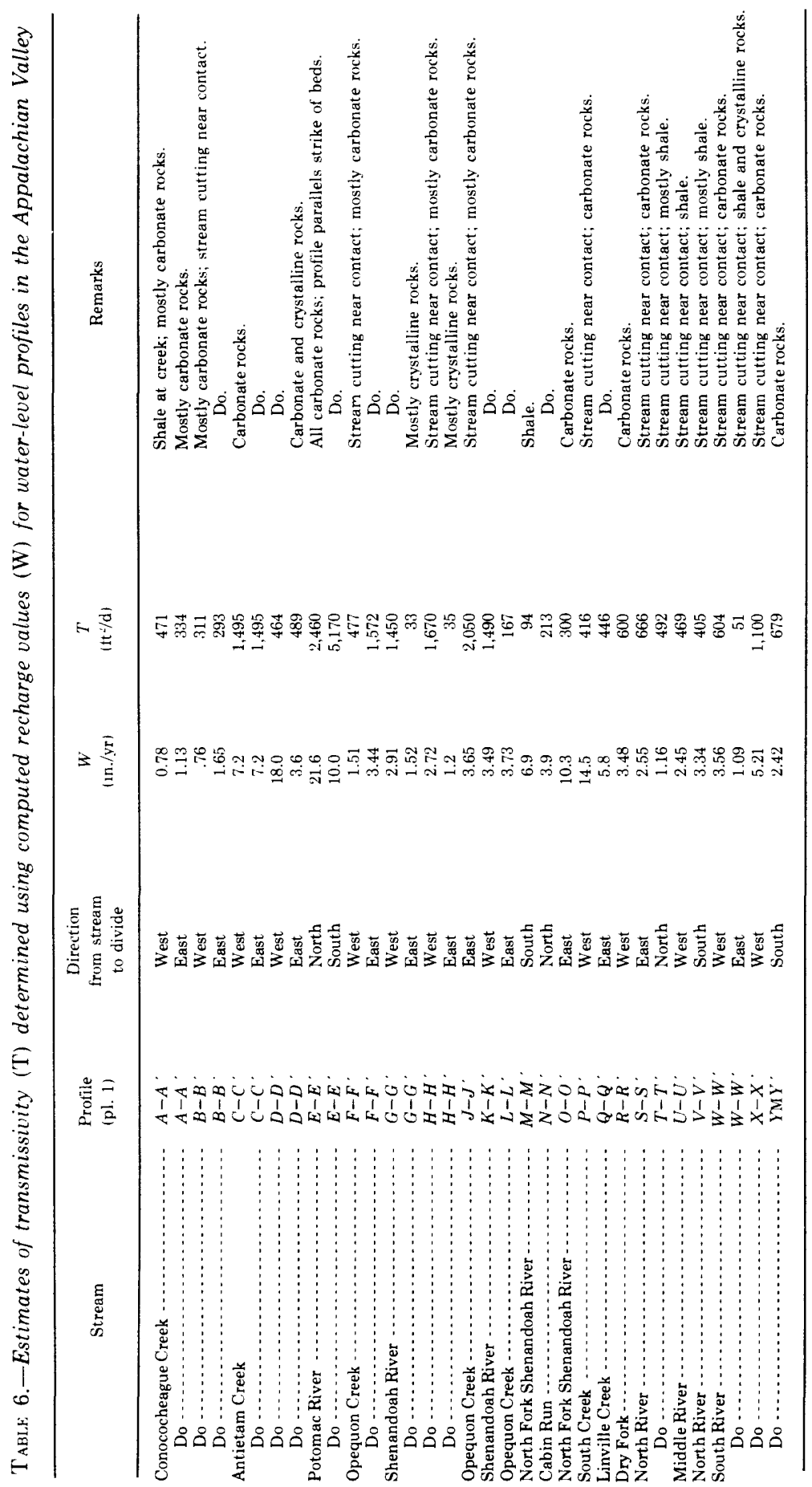


episodes in this humid region makes the recession curves difficult to establish precisely, (2) losses from ground water and from streamflow above the river gage through evapotranspiration distort the ideal recession curve during much of the year, and (3) many recession curves are complex because of nonhomogeneity of the aquifers.

\section{EFFECT OF DURATION OF STREAMFLOW RECESSION}

Equation 7 is valid only after sufficient time has elapsed for stabilization of the water-table profile after recharge. The critical time, $t_{c}$, for stabilization (Rorabaugh, 1964, p. 434) is

$$
t_{c}=\frac{0.2 a^{2} S}{T} .
$$

Thus, equation 7 is valid after the lapse, after a flood peak, of a period that is about one-fifth the time required for the straight-line recession curve to decline through one log cycle of discharge. For example, if the base-runoff recession curve for a given stream declines through one log cycle in 40 days, the semilog hydrograph should become a straight line after about 8 days of uninterrupted recession after a flood peak. If the time required is 200 days per cycle, the straight-line form should be attained in about 40 days. The time values in these examples-50 and 200 days-represent the range found in recession curves for most of the tributary basins studied in the upper Potomac River basin.

Great care is required in constructing the recession curve of base runoff from the river hydrograph because storms are frequent in the Potomac River basin and periods of streamflow recession between flood peaks are relatively short. On the average, there are several storms per month, and periods of a month or more without precipitation are rare. A recession curve that becomes linear on the semilog plot within 8 to 10 days after a flood peak can be determined readily through study of several years of the river hydrograph. On the other hand, the straightline part of a curve that would become linear only after 30 or 40 days of uninterrupted recession can be determined only approximately. A recession curve constructed from hydrograph segments that have not quite attained the straight-line form is somewhat steeper than the true curve; therefore, it overestimates the rate of decline of base runoff and leads to underestimation of the base runoff for a given period.

\section{EFFECT OF EVAPOTRANSPIRATION}

Many hydrologists have recognized seasonal forms of the recession curve, the "winter" and "summer" curves. The "winter" curve is the more gently sloping of the two, indicating a less rapid decline in the rate of discharge. It probably represents recession that is little afftected by evapotranspiriation and, hence, reflects the geohydrologic control of base runoff. In the Potomac River basin the "winter" curve is easily 
recognized in many recession episodes during October to April, but its slope is difficult to determine because many of the recessions are brief. Our analysis suggests that each tributary basin is characterized by one "winter" recession curve, which approaches a straight line on a semilog plot.

Some recessions during October to April and most of them during the remainder of the year can be fitted by a "summer" curve which, like the "winter" curve, is nearly straight on a semilog plot. However, some recessions during late summer and early autumn, when streamflow is no more than a few cubic feet per second, are fitted to a "summer" curve that becomes progressively steeper as the season advances. This curvature, which is particularly common for basins underlain by fairly impermeable rocks in the Potomac River basin, has been well shown in other studies (for example, Riggs and Hanson, 1969) and is widely recognized to reflect evapotranspiration from ground-water bodies near the stream and from the stream itself, above the gaging station. In part, however, it must also be due to seasonal decrease in transmissivity of the unconfined aquifer, a factor considered briefly in the next section.

Figure 8 shows "winter" and "summer" recession curves for two tributary streams in the upper Potomac River basin.

If a recession curve is to be used to study geohydrologic controls on base runoff, the "winter" curve should be used in estimating the slope of the recession curve. Use of the "summer" curve for this purpose would result in an erroneously high slope and a correspondingly high rate of decline in base runoff. On the other hand, if the recession curve is to be used to study summer streamflow as related, for example, to water-supply problems, the "summer" curve might be applicable.

\section{COMPLEXITY OF RECESSION CURVES}

Both vertical and areal differences in characteristics of the unconfined aquifer probably contribute to complexity of the recession curve.

The normal downward closure of rock joints causes downward decrease in porosity and permeability. We believe that in some fractured rocks these changes may be appreciable even within the zone of annual water-table fluctuation. During the late-summer period of low ground-water level, the resulting decreases in transmissivity and storage coefficient in these rocks may lead to increase in the rate of

Figure 8.-Base-runoff recession curves (dotted lines) constructed from segments of stream hydrographs (solid lines). Absolute positions of time scales are arbitrary. $A$, Passage Creek at Buckton, Va.: "winter" curve (above); "summer" curve (below). Steeper segments of "summer" curve are typical of very dry years. $B$, South Branch Potomac River at Franklin, W. Va.: generalized annual recession curve (left); curve for 1953 (right). Gentle segment of annual curve is a "summer" curve. 


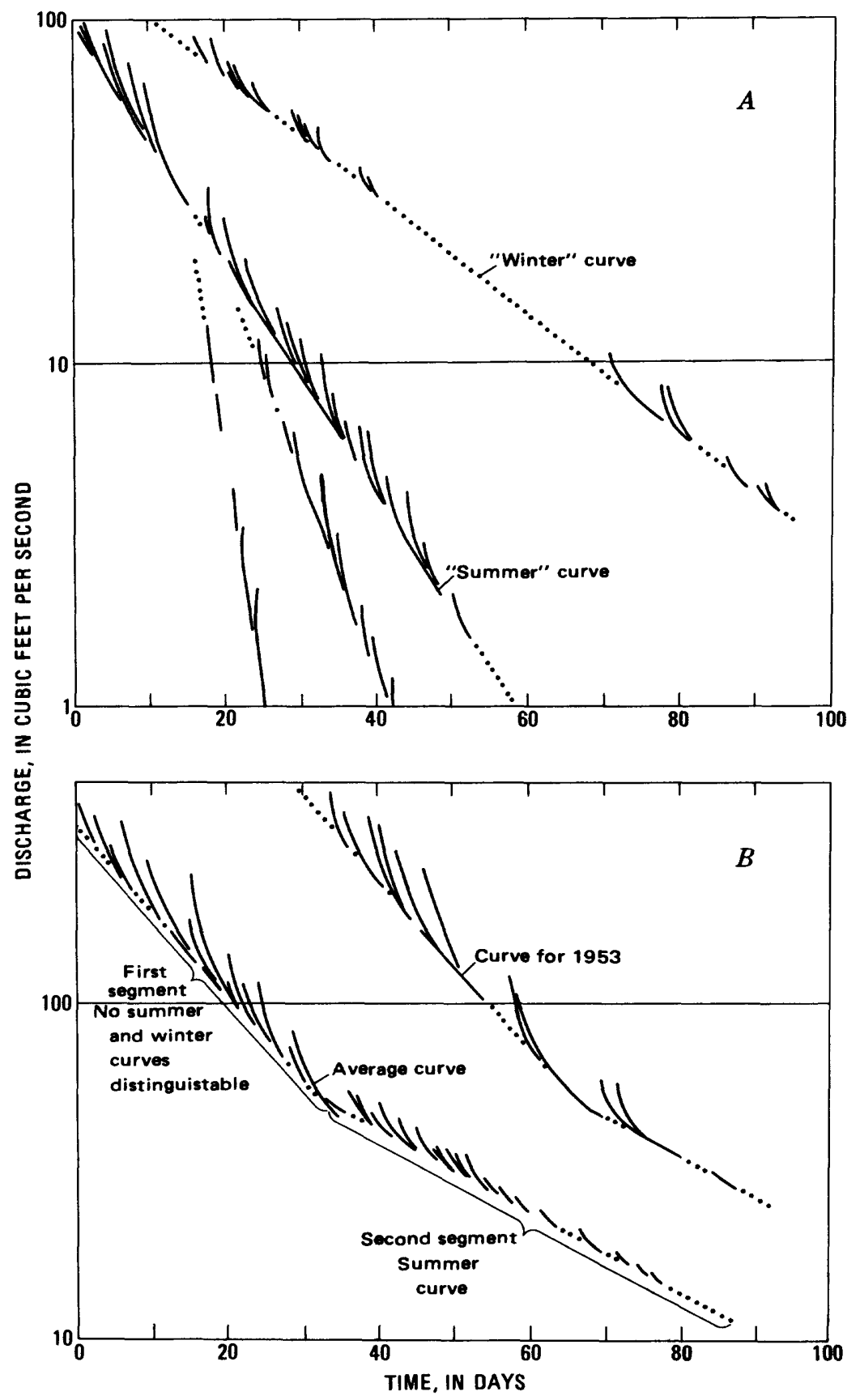


base-runoff recession; this would cause the "summer" recession curve to become concave downward, reinforcing the concavity due to evapotranspiration.

The recession curves in figure 8 were constructed graphically from segments of river hydrograph representative of, or approaching, the base-runoff regime. The curves in figure $8 A$ are based on segments selected from several annual hydrographs. In a given year, the recession of base runoff follows the "winter" curve during periods of very low evapotranspiration, and it follows the most gently sloping "summer" curve during much or all of the remainder of the year. During very dry years, however, the "summer" curve may become concave downward at progressively lower levels of discharge, as indicated by the several steeper segments shown in figure $8 A$. The recession curve representing an entire year is thus complicated by evapotranspiration. However, the annual course of recession can be thought of as following a single continuous curve which may consist of several straight-line segments but which generally is concave downward and lacks any major sharp break in slope. The continuity of this curve (disregarding seasonal differences caused by evapotranspiration) implies that hydraulic characteristics of the aquifer (expressed as the ratio $T / a^{2} S$ ) have a continuous range of values throughout the tributary basin. Although the rocks may be diverse, geohydrologic conditions are fundamentally similar throughout the tributary basin.

Figure $8 B$ is typical of recession curves constructed for many tributary basins in the Potomac River basin. The gently sloping second segment, which defines base runoff only during summer and autumn, when evapotranspiration is high, is considered a "summer" curve. The steeply sloping first segment defines base runoff during winter and spring. We have been unable to identify winter and summer forms of the first segment. The recession curves in figure $8 B$ differ markedly from those in figure $8 A$ in being concave upward and in having a distinct break in slope. This discontinuity shows that the ratio $T / a^{2} S$ is not continuous throughout the tributary basin, so we infer that the basin has two regions of unlike aquifer characteristics.

Tributary basins in the Potomac River basin that have a simple, or continuous, recession curve are underlain by sandstone, shale, or crystalline rock, by a combination of these rocks, or by carbonate rock. Basins that have a compound, or discontinuous, curve are underlain in part by carbonate rock and in part by noncarbonate rock. Riggs (1964) suggested that the combined runoff of two very unlike aquifers in a single basin may yield a compound recession curve. Following this reasoning, we believe that in the Potomac River basin the first, steep segment of the compound curve represents the combined ground-water runoff from carbonate and noncarbonate aquifers during winter and spring, when both aquifers are contributing to the streamflow at 
relatively high rates, and that the second, gentle segment is very nearly the summer recession curve for the carbonate aquifer, which during summer and autumn provides much or most of the base runoff while discharge from the noncarbonate aquifer is low.

The discharge at which inflection occurs in the compound curve differs from year to year in a given basin, and it differs from one basin to another. The discharge at a given inflection depends, of course, on the relative values of the ratio $T / a^{2} S$ for the two aquifers, on the relative recharge to each aquifer during a given storm or season, and on the relative recession status of each aquifer before the inflection.

Table 7 presents typical examples of the slopes of recession curves in the upper Potomac River basin. The tributary basins are classified into three groups, each having a distinctive geohydrology:

1. Basins underlain by fractured rock that has a thin regolith. This terrane, which typically consists of tight sandstone, shale, or crystalline rock, is found in parts of the Blue Ridge and the Valley and Ridge provinces and in the Appalachian Plateaus province. Values for $\Delta t$ for the recession curve range from 45 to 63 days.

2. Basins underlain by fractured rock that has a thick regolith. This terrane, in most of the Piedmont province and in the lowland part of the Blue Ridge province, consists of sandstone, shale, or crystalline rock; carbonate rock may underlie a small part of this terrane. Values for $\Delta t$ range from 35 to 127 days.

3. Carbonate rock that locally is covered by a thick regolith and in which fractures have locally been enlarged by solution. This terrane underlies much of the Appalachian Valley, parts of other valleys in the Valley and Ridge province, and small areas in the Piedmont province. Values for $\Delta t$ are as much as several hundred days.

The higher values of $\Delta t$, which represent the gentle, second segments of the compound curves, are approximations at best because the brevity of most recession episodes precludes determination of precise values. Also, in some basins the slope of the recession curve has been affected by streamflow regulation, which is slight but is sufficient to affect the slope for very low flows. High values of $\Delta t$ can, however, be accepted as valid for some basins. Carbonate rock in the Potomac basin is commonly a much more productive aquifer than noncarbonate rock, and streamflow measurements (cited in a later section of this report) show that average base runoff is higher from carbonate rock than from noncarbonate rock. Moreoever, many carbonate-rock basins characterized by recession curves (second segment) of gentle slope are in part underlain by thick regolith and by alluvial-fan deposits, whose drainage may help sustain base runoff. We believe that large values for $\Delta t$ (low slopes of recession curves) are valid for these basins. Precise slopes cannot be determined, however, nor can the quantitative significance of the 
TABLE 7.-Descriptors for slopes of base-runoff recession curves and spring base runoff for selected tributary basins

\begin{tabular}{|c|c|c|c|}
\hline Station $^{1}$ & Tributary basin & $\begin{array}{c}2 \Delta t \\
\text { (days/cycle) }\end{array}$ & $\begin{array}{l}\text { Base runoff } \\
(\mathrm{cfs} / \mathrm{sq} \mathrm{mi})\end{array}$ \\
\hline
\end{tabular}

Basins underlain by fractured rock having thin regolith

\begin{tabular}{|c|c|c|c|}
\hline 5965 & Savage River near Barton, Md $\ldots \ldots \ldots$ & 56 & 0.82 \\
\hline 5970 & 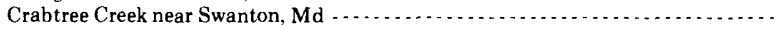 & 52 & 1.02 \\
\hline 6045 & 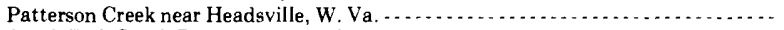 & 63 & .36 \\
\hline 6075 & South Fork South Branch Potomac River at Brandywine, V. Va. $\ldots \ldots$ & 59 & 59 \\
\hline 6140 & Back Creek near Jones Spring, W. Va & 56 & .44 \\
\hline 6205 & 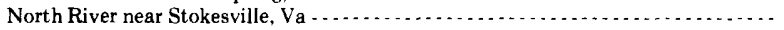 & 45 & 1.27 \\
\hline 6320 & North Fork Shenandoah River at Cootes Store, Va. & 54 & .46 \\
\hline 6345 & 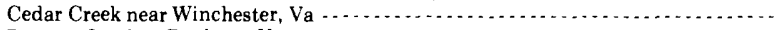 & 60 & .61 \\
\hline 6355 & Passage Creek at Buckton. Va $\ldots \ldots \ldots$ & 57 & .57 \\
\hline 6362.1 & Happy Creek at Front Royal, $\mathrm{Va} \ldots \ldots$ & 45 & .87 \\
\hline 6405 & Owens Creek at Lantz, Md $\ldots \ldots$ & 57 & 1.48 \\
\hline 6410 & 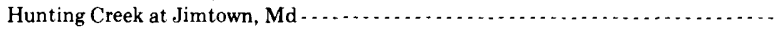 & 57 & $\therefore 26$ \\
\hline 6415 & 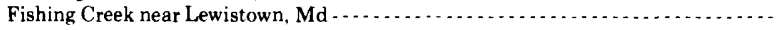 & 55 & 1.71 \\
\hline
\end{tabular}

Basins underlain by fractured rock having thick regolith

\begin{tabular}{|c|c|c|c|}
\hline 6375 & 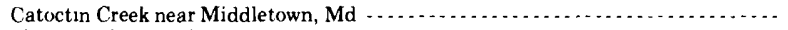 & 46 & 0.88 \\
\hline 6390 & Monocacy River at Bridgeport, Md & 35 & .45 \\
\hline 6395 & Big Pipe Creek at Bruceville, Md & 94 & .85 \\
\hline 6425 & Linganore Creek near Frederick, Md & 105 & .92 \\
\hline 6440 & Goose Creek near Leesburg, $\mathrm{Va}$ & 71 & .66 \\
\hline 6450 & Seneca Creek at Dawsonville, Md $\ldots$ & 127 & .87 \\
\hline 6460 & Difficult Run near Great Falls, Va & 90 & .86 \\
\hline
\end{tabular}

Basins underlain by carbonate rock

\begin{tabular}{|c|c|c|c|}
\hline 6145 & Conococheague Creek at Fairview, Md $\ldots \ldots \ldots$ & 111 & 1.24 \\
\hline 6150 & Opequon Creek near Berryville, Va $\ldots$ & 84 & .21 \\
\hline 6165 & Opequon Creek near Martinsburg, W. Va $\ldots \ldots \ldots \ldots$ & 155 & .60 \\
\hline 6170 & Tuscarora Creek above Martinsburg, W. Va $\ldots \ldots$ & 100 & 1.08 \\
\hline 6195 & 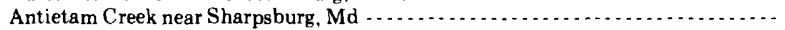 & 244 & 1.26 \\
\hline 6220 & North River near Burketown, Va & 292 & .98 \\
\hline 6250 & Middle River near Grottoes, Va $\ldots \ldots$ & 184 & .89 \\
\hline 6260 & South River near Waynesboro, Va $\ldots \ldots \ldots \ldots \ldots$ & 299 & 1.46 \\
\hline 6285 & South Fork Shenandoah River near Lynnwood, Va $\ldots \ldots \ldots \ldots$ & 242 & 1.11 \\
\hline 6310 & South Fork Shenandoah River at Front Royal, Va $\ldots \ldots \ldots$ & 541 & 1.08 \\
\hline 6330 & North Fork Shenandoah River at Mount Jackson, Va $\ldots \ldots \ldots \ldots$ & 58 & .46 \\
\hline 6340 & 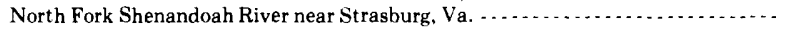 & 108 & 70 \\
\hline 6365 & Shenandoah River at Millville, W. Va $\ldots \ldots \ldots$ & 229 & .80 \\
\hline
\end{tabular}

'Stream-gaging station, U.S. Geological Survey.

'Time required for base-runoff recession curve to decline through one log cycle of discharge

${ }^{3}$ Basins in Appalachian Valley. Base-runoff recession curve used was second segment of curve for tributary basin. Discharge from carbonate rock alone was computed from basin discharge, using probable value of discharge from noncarbonate rock.

several geologic factors that influence these slopes yet be determined.

Base-runoff data in table 7 are representative of the spring season. The data were obtained as follows: Streamflow records for the upper Potomac River basin were searched for recession episodes that occurred in all parts of the basin after basinwide storms. Four such episodes, during February to April, were found for 1950-66. Discharge in each tributary basin, just before interruption of recession by a new flood peak, was averaged for the four episodes. These averages, expressed on a unit-area basis, are taken for the purpose of this comparative study as representative values for base runoff during spring. 


\section{ESTIMATES OF AQUIFER CHARACTERISTICS}

An average value for aquifer diffusivity in the fractured rocks having thin regolith was computed from equation 7 , using representative average values for $\Delta t$ (55 days) and $a(1,350 \mathrm{ft})$. Distance $a$ was determined from the relation $A=2 a L$, where $A$ is basin drainage area, $a$ is average distance from stream to divide, and $L$ is total length of streams in the basin. From equation 7 ,

$$
\begin{aligned}
\frac{T}{a^{2} S} & =\frac{0.933}{\Delta t / \text { cycle }} \\
\frac{T}{(.9)\left(1.8 \times 10^{6} \mathrm{ft}^{2}\right) S} & \approx \frac{1}{55 \text { days }} \\
\frac{T}{S} & \approx \frac{1.6 \times 10^{6} \mathrm{ft}^{2}}{55 \text { days }}=29,000 \mathrm{ft}^{2} / \mathrm{d} .
\end{aligned}
$$

$T$ or $S$ can be estimated from the diffusivity, given a value for $S$ or $T$, respectively. We assumed $S$ (because it falls in a narrower range of values in the upper Potomac River basin than $T$ ) and computed $T$. Seven values for $S$ determined by pumping tests (tables 2 and 3 ) range from 0.002 to 0.02 ; the median value is 0.006 . The median value for gravity yield determined from watertable fluctuation (table 4) is 0.004 . Assuming $S$ to average 0.005 , the average transmissivity is $140 \mathrm{ft}^{2} / \mathrm{d}$.

In a similar fashion, $T / S$ was computed for fractured rocks covered by thick regolith (fig. $11 B$ ). Taking $a$ as 1,250 feet and $\Delta t$ as 80 days, we obtained an average value for $T / S$ of $18,000 \mathrm{ft}^{2} / \mathrm{d}$. An average value for $S$ from pumping tests (tables 2 and 3 ) is less than 0.01 , but we assumed that over an entire tributary basin it is somewhat higher. Olmsted and Hely (1962, p. A17), for terrane in the Piedmont province in Pennsylvania that is similar to that in the Potomac River basin, computed the average gravity yield (approximately equal numerically to storage coefficient) to be about 0.07 to 0.10 . Using the same method, we determined values of 0.005 to 0.02 , with a median of 0.01 (table 4). Assuming an average $S$ value of 0.01 for the Potomac basin terrane, the estimated average transmissivity is $180 \mathrm{ft}^{2} / \mathrm{d}$.

For the carbonate rock ( $a=1,800 \mathrm{ft}, \Delta t=180$ days), an average value for $T / S$ was computed to be $16,000 \mathrm{ft}^{2} / \mathrm{d}$. Assuming $S$ is 0.03 , the estimated average transmissivity is $480 \mathrm{ft}^{2} / \mathrm{d}$.

\section{SUMMARY OF HYDRAULIC CHARACTERISTICS}

Hydraulic characteristics of aquifers in the upper Potomac River basin were estimated through the use of five methods. Pumping tests were used to determine transmissivity and, in some tests, the storage coefficient. The relation between water-table fluctuations and base runoff was used to estimate gravity yield, which approximates the 
storage coefficient of the zone of water-table fluctuation. Water-table gradients, taken with base runoff, provided estimates of transmissivity. Finally, rates of water-table recession in wells and of base-runoff recession in streams were used to determine aquifer diffusivity (the ratio of transmissivity to storage coefficient). Table 8 summarizes these estimates of hydraulic characteristics.

\section{STORAGE COEFFICIENT}

Storage coefficients computed from the pumping-test data range from 0.00002 to 0.14 . Nearly half the coefficients are typical of confined, or artesian, and of semiconfined, or leaky artesian, conditions (under which $S$ is, roughly, 0.001 or smaller), and about half represent the unconfined, or water-table, condition (under which $S$ is, roughly, 0.01 or larger). All these values provided by pumping tests represent regions near the test wells. In such relatively small regions the confined or semiconfined conditions are readily explained by local confinement of water-bearing openings in the rocks-perhaps openings such as horizontal solution tubes cut by only a few vertical joints in carbonate rock; or fractures in the uppermost part of the noncarbonate rock beneath its regolith.

Storage coefficients determined through analysis of water-table fluctuations are of a magnitude similar to that of coefficients determined from pumping-test data.

We believe the median values are more nearly representative of averages for the aquifers than the computed average values, considering the small number of coefficients obtained. The following are suggested as reasonable average storage coefficients: fractured rock having thin regolith, half of 1 percent; fractured rock having thick regolith, about 1 percent; and carbonate rock, 3 to 4 percent.

\section{DIFFUSIVITY}

Aquifer diffusivity was determined by two methods, which yielded results that do not compare well. These methods, which utilize measures of water-table recession or base-runoff recession, are based on the same equation. The discrepancy in results probably reflects the degree to which the real conditions in one or both methods resemble the conditions assumed in application of the equation. Transmissivity was computed by substituting representative storage coefficients in the diffusivity values. (See last column, table 10.) Taking the other available transmissivity values as a standard for comparison, we conclude that diffusivity determined from base-runoff recession is about the correct magnitude, whereas that determined from water-table recession is too small.

\section{TRANSMISSIVITY}

Within each of the three types of aquifers there is considerable range in the transmissivities determined. However, this range is largely 


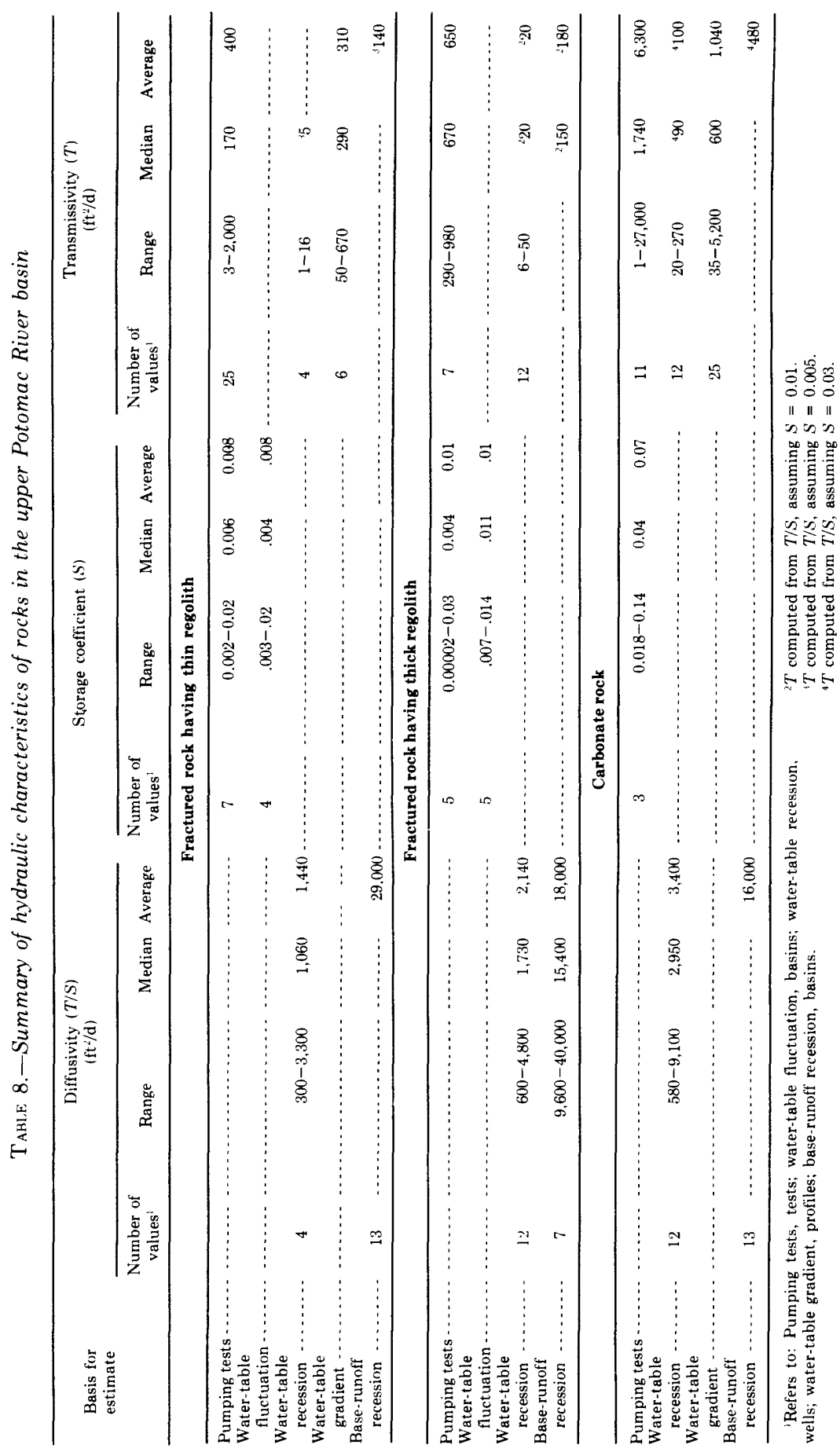


dependent on the type of test used. Among the tests, the greatest and least absolute values and the greatest average values were commonly found in pumping tests, any one of which represents a relatively small part (areally) of the aquifer. Because most pumping tests were probably made in wells already known to be successful, the results may to some degree represent the more favorable parts of the aquifers, and the relatively high values at the upper ends of the ranges lead to large average values. Determinations based on water-table gradients and base-runoff recession, which represent much larger parts of the aquifers, are lower than those from pumping tests and can be thought of as averages for large areas, such as entire tributary basins.

On the basis of data representing large areas, fractured rock having thin regolith consistently has the lowest transmissivity of the three terranes studied. Fractured rock having thick regolith has a somewhat higher transmissivity, and carbonate rock has a transmissivity several times greater. On the basis of data for small areas, transmissivities in the three terranes are comparable at the low end of the range, but carbonate rock has high transmissivities that are much higher than high values in the other rocks. All aquifers whose fractures are unmodified tend to have similar low transmissivities, but carbonate-rock aquifers commonly have many modified fractures, which cause their transmissivity values to range much higher. Average transmissivities in the three terranes are probably about $150 \mathrm{ft}^{2} / \mathrm{d}$ (fractured rock having thin regolith), $200 \mathrm{ft}^{2} / \mathrm{d}$ (fractured rock having thick regolith), and 500 $\mathrm{ft}^{2} / \mathrm{d}$ (carbonate rock).

\section{BASE RUNOFF AND LOW FLOW OF STREAMS}

As described in the preceding section of this report, base runoff was used in the determination of aquifer characteristics in representative terranes. We were concerned with base runoff during the spring season, which has high ground-water levels, high streamflow, and low evapotranspiration. This section describes base runoff under the more stringent conditions of summer, when ground-water levels and streamflow are lower than in spring and evapotranspiration is high. The streamflow characteristics used are mean annual base runoff (one estimate) and frequency of low flow (two measures). So far as possible, these flow characteristics were computed from streamflow records for the 20-year period 1948-67, although longer or shorter periods of record were used for some stations.

Mean annual base runoff was estimated by a method that uses the streamflow-duration curve. Through separation of hydrogrpahs for the water years 1953-57, we estimated the mean daily base runoff from 17 tributary basins. These mean daily discharges were matched with the discharge values on flow-duration curves representing these basins for this 5-year period. The estimated base-runoff discharges correspond to 
discharge values on the flow-duration curve that range from 39 to 61 percent and average 52 percent. In this report the 52-percentile discharge value is used as an estimate of the mean daily base runoff of a stream in the upper Potomac River basin.

Two low-flow characteristics are used: the minimum 7-day mean low flows at recurrence intervals of 2 and 10 years $\left(M_{7,2}\right.$ and $M_{7,10}$, respectively). Such measures of the frequency of low flows are of wide application in study of the availability of streamflow for water supply and other uses.

\section{GEOLOGIC CONTROL OF BASE RUNOFF}

Two methods were used to study the relation of streamflow to geology: (1) correlation of fair-weather discharge from selected small basins underlain by representative rock types with discharge, on the same dates, from nearby gaged basins of similar geology; and (2) correlation of selected streamflow characteristics of gaged basins underlain by these rock types with the recession curves of base runoff for these basins. In the first method, measurements of runoff were used for correlation, and $Q_{52}$ and $M_{7,2}$ were inferred from these correlations. (For definitions of flow characteristics see tables 9 and 10.) In the second method, gaging-station records of $M_{7,2}$ and $M_{7,10}$ were used to relate base runoff to aquifer characteristics.

\section{BASE RUNOFF AND LOW FLOW FROM SMALL BASINS}

Table 9 summarizes streamflow characteristics determined from miscellaneous measurements. The streams are classified in terms of the three geohydrologic terranes in the upper Potomac River basin-fractured rock having thin regolith, fractured rock having thick regolith, and carbonate rock.

The basins with thin regolith are underlain by sandstone and shale or by crystalline rock. The data suggest a large difference in average base runoff $\left(Q_{52}\right)$ from these two types of rock; thus, a median value, or an average value, of base runoff for all basins with thin regolith is influenced by the relative numbers of basins underlain by these rock types. Similarly, the basins with thick regolith are underlain by crystalline rock or by sandstone, shale, and diabase; and a median, or an average, value of base runoff for this entire group of basins is influenced by the rock types in the basins sampled. Bearing this qualification in mind, we see that average annual base runoff from basins with thick regolith is appreciably greater than that from basins with thin regolith-0.44 as compared with $0.21 \mathrm{cfs} / \mathrm{sq} \mathrm{mi}$, a difference that seems significant even though the data do not warrant precise quantitative comparison. Basins underlain largely by carbonate rock yield markedly higher mean annual base runoff $(0.56 \mathrm{cfs} / \mathrm{sq} \mathrm{mi})$ than the other two terranes. 


\section{TABLE 9.-Base runoff and low flow from representative small basins}

[Determined by correlation of miscellaneous streamflow measurements with streamflow from gaged basins. Measurements made during 1968-69 for fractured rock having thin regolith and for carbonate rock and during 1968-70 for fractured rock having thick regolith]

\begin{tabular}{|c|c|c|c|c|}
\hline Basin & $\begin{array}{c}\text { Drainage } \\
\text { area } \\
\text { (sq mi) }\end{array}$ & $\begin{array}{c}\text { Dominant rock } \\
\text { type }\end{array}$ & $\begin{array}{c}{ }^{1} Q_{52} \\
\text { (cfs/ } \\
\text { sq mi) }\end{array}$ & 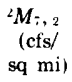 \\
\hline
\end{tabular}

BASINS UNDERLAIN BY FRACTURED ROCK HAVING THIN REGOLITH

\begin{tabular}{|c|c|c|c|c|}
\hline North River near Bloomery, W. Va. ${ }^{3}$. & 183 & Sandstone, shale & 0.21 & 0.06 \\
\hline Isaac Creek near Winchester, $\mathrm{Va}, \ldots \ldots \ldots \ldots \ldots$ & 15.8 & 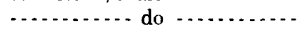 & .16 & .01 \\
\hline Swover Creek near Conicville, Va. . . . . . . . . & 3.26 & $\ldots$ do $\ldots . .6$. & .16 & .04 \\
\hline Riles Run near Conicville, Va. . . . . . . . & 5.65 & 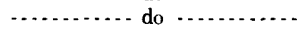 & .12 & .01 \\
\hline Toms Brook near Toms Brook, Va. ${ }^{4} \ldots \ldots \ldots \ldots$ & 6.85 & Shale $\ldots \ldots \ldots$ & .21 & .13 \\
\hline Peters Mill Run near Dietrich, Va. . . . . . . . . . & 4.22 & Sandstone, shale $\ldots \ldots$ & .24 & .06 \\
\hline Madison Run near Grottoes, Va. . . . . . . . . & 5.78 & Crystalline rock ............. & .38 & .03 \\
\hline Gooney Run near Glen Echo, Va. . . . . . . . . & 20.6 & $\ldots$ do $\ldots \ldots \ldots$. & .67 & .03 \\
\hline
\end{tabular}

BASINS UNDERLAIN BY FRACTURED ROCK HAVING THICK REGOLITH

Blue Ridge-Piedmont province west of Triassic Lowland

\begin{tabular}{|c|c|c|c|c|}
\hline Toms Creek near Fairfield, $\mathrm{Pa} . \ldots \ldots \ldots \ldots \ldots$ & 10.1 & Schistose metavolcanic rock. & 0.90 & 0.05 \\
\hline Middle Creek near Fairfield, Pa. . . . . . . . . 19.0 & 19.0 & $\begin{array}{l}\text { Crystalline rock, sandstone, } \\
\text { diabase, and carbonate rock. }\end{array}$ & .77 & .13 \\
\hline Catoctin Creek at Taylorstown, Va. ... & 89.5 & Gneissic and schistose rock. & .27 & .02 \\
\hline Goose Creek near Middleburg, $\mathrm{Va}^{5} \ldots \ldots \ldots \ldots \ldots$ & 123 & - & .44 & .06 \\
\hline Goose Creek near Oatlands, Va. ........... & 276 & - $\ldots$ do $\ldots$ do. & .38 & .03 \\
\hline Little River near Oatlands, Va. . . . . . . . . . . & 47.7 & $\ldots$ do $-\ldots . .6$. & .45 & .08 \\
\hline
\end{tabular}

Triassic Lowland

Plum Run near Barlow, $\mathrm{Pa} \ldots \ldots \ldots \ldots \ldots \ldots \ldots . .4$

Rock Creek near Barlow, $\mathrm{Pa} \ldots \ldots \ldots \ldots \ldots \ldots \ldots 46.8$

Marsh Creek near Emmitsburg, Md ......... 78.6

Piney Creek near Menges Mill, Pa ............ 9.62

South Fork Broad Run at Arcola, Va .......... 5.31

\begin{tabular}{|c|c|c|}
\hline Diabase and shale $\ldots \ldots \ldots \ldots$ & 0.18 & 0.01 \\
\hline$\ldots \ldots$ do $\ldots \ldots \ldots \ldots$ & .24 & .02 \\
\hline$\ldots \ldots$ do $-\ldots \ldots \ldots$ & .44 & .01 \\
\hline Sandstone $\ldots . . . . . . . .$. & .57 & .19 \\
\hline Diabase $\ldots \ldots \ldots$ & .13 & .01 \\
\hline
\end{tabular}

Piedmont province east of Triassic Lowland

\begin{tabular}{|c|c|c|c|}
\hline 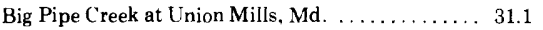 & Schistose rock ............. & 0.69 & 0.23 \\
\hline Meadow Br. at Weishaars Mill, Md. . . & ........ do & .61 & .26 \\
\hline
\end{tabular}

\section{BASINS UNDERLAIN LARGELY BY CARBONATE ROCK}

\begin{tabular}{|c|c|c|c|}
\hline Cove Creek near McConnellsburg, $\mathrm{Pa} \ldots \ldots \ldots \ldots 10.3$ & Carbonate rock $\ldots . . . . .$. & 0.48 & 0.07 \\
\hline $\begin{array}{l}\text { West Branch Conococheague Creek near } \\
\text { Mercersburg, Pe. }\end{array}$ & $\ldots . . . . . .6$ do & .59 & .20 \\
\hline Conococheague Creek near Chambersburg, $\mathrm{Pa} . \ldots 91.4$ & $\ldots \ldots \ldots$ do $\ldots \ldots . .6$. & .45 & .07 \\
\hline Mill Creek near Bunker Hill, W. Va. . . . . . . . 18.6 & $\ldots$ do $\ldots \ldots . . .6$. & .56 & .11 \\
\hline Hopewell Run near Leetown, W. Va. . . . . . . . 2.7 & $\ldots$ do $\ldots . . .6$. & .76 & .33 \\
\hline West Branch Antietam Creek at Waynesboro, $\mathrm{Pa}$. . 17.1 & $\ldots \ldots$ do $\ldots \ldots$. & .59 & .39 \\
\hline Linvill Creek at Broadway, Va. . . . . . . . . . . 42.3 & $\ldots \ldots \ldots$ do $\ldots \ldots \ldots$ & .26 & .15 \\
\hline Stony Creek at Edinburg, $\mathrm{Va}{ }^{6} \ldots \ldots \ldots \ldots \ldots 47$ & $\ldots$ do $\ldots \ldots \ldots$. & .53 & .32 \\
\hline Cedar Creek near Strasburg, $\mathrm{Va}^{7} \ldots \ldots \ldots \ldots \ldots 107$ & $\ldots \ldots$ do $\ldots \ldots \ldots$. & .30 & .10 \\
\hline Buffalo Marsh Run near Middletown, Va. . . . . . . 5.27 & $\ldots \ldots$ do $\ldots \ldots \ldots$ & .46 & .26 \\
\hline Westbrook Run near Boyce, Va. . . . . . . . . . 1.40 & $\ldots \ldots$ do $-\ldots . . .6$ & .75 & .22 \\
\hline Dry Marsh Run near Berryville, Va. . . . . . . . 11.4 & $\ldots \ldots . . .6$ do $\ldots \ldots \ldots$ & .88 & .40 \\
\hline Evitts Run near Charles Town, W. Va. ....... 3.5 & $\ldots$ do $\ldots \ldots \ldots$ & 1.4 & .80 \\
\hline
\end{tabular}

${ }^{1} 52$-percentile discharge on streamflow-duration curve; used as an estimate of mean daily base runoff.

'Minimum mean 7-day low flow at 2-year recurrence interval.

${ }^{3}$ North River above junction with Cacapon River.

${ }^{4}$ Area drained between village of Toms Brook and point near mouth of stream.

'Daily discharge data for low flows, during short period of gaging-station record, used instead of miscellaneous measurements.

${ }_{6}^{6}$ Discharge from part of basin between Liberty Furnace and Edinburg.

Discharge from part of basin between Star Tannery and Strasburg. 
Median values of low flow $\left(M_{7,2}\right)$ observed during late summer are roughly comparable for the two noncarbonate-rock terranes-0.04 as compared with $0.05 \mathrm{cfs} / \mathrm{sq} \mathrm{mi}$-although the ranges of values suggest that basins with thick regolith (range 0.01 to $0.26 \mathrm{cfs} / \mathrm{sq} \mathrm{mi}$ ) are more productive than those with thin regolith (range 0.01 to $0.13 \mathrm{cfs} / \mathrm{sq} \mathrm{mi}$ ). On the other hand, the median low flow for basins underlain largely by carbonate rock is $0.22 \mathrm{cfs} / \mathrm{sq} \mathrm{mi}$, and the range is 0.07 to $0.80 \mathrm{cfs} / \mathrm{sq} \mathrm{mi}$. Thus, in the carbonate-rock basins low flow is about 40 percent of base runoff $\left(Q_{52}\right)$, whereas in noncarbonate-rock basins, this proportion is 10 to 20 percent. The higher dependability of low flow from the carbonate rock and the lesser dependability of that from the other rocks is the most striking conclusion drawn from study of the miscellaneous streamflow measurements.

For several reasons, more detailed conclusions were not drawn from the data in table 9. Several streams receive waste discharges, which increase their flow, but we lack data needed to assess this effect. Drainage area is difficult to determine precisely in carbonate-rock terrane, and some of the discharges for carbonate rock are undoubtedly too high for this reason. Several of the basins with thick regolith extend, in their headwater regions, into mountainous parts of the Blue Ridge, which are characterized by thin regolith. Despite these qualifications, however, the principal conclusions drawn in the preceding paragraphs are consistent with those based on study of gaging-station records, as discussed in the following paragraphs.

\section{LOW FLOW IN GEOHYDROLOGIC TERRANES}

Table 10 summarizes two streamflow characteristics $\left(M_{i, 2}\right.$ and $\left.M_{7,10}\right)$ in the principal bedrock geohydrologic terranes in the upper Potomac River basin.

A plot of $M_{7,10}$ against $M_{i, 2}$ for carbonate-rock terrane (fig. $9 B$ ) suggests, by its linearity, a considerable degree of homogeneity in low flow from these basins as compared with the noncarbonate-rock basins (fig. 9A). Moreoever, the greater $M_{7,10}: M_{7,2}$ ratios for the carbonaterock basins show greater low-flow productivity under conditions of increasing drought. The distribution of points in figure $9 A$ suggests that the noncarbonate-rock basins may constitute one group or two but that in either case they have similar $M_{7,10}: M_{7,2}$ ratios that are considerably smaller than those of most carbonate-rock basins.

\section{AREAL DISTRIBUTION OF LOW FLOW}

Major tributaries in the upper Potomac River basin yield similar amounts of total runoff per unit area. The areal distribution of low flows, which occur during periods of low ground-water storage and high evapotranspiration, is much more irregular, however, and reflects the restricted distribution of the more productive aquifers. Thus, the values 
T ABLE 10.-Low flow from representative tributary basins

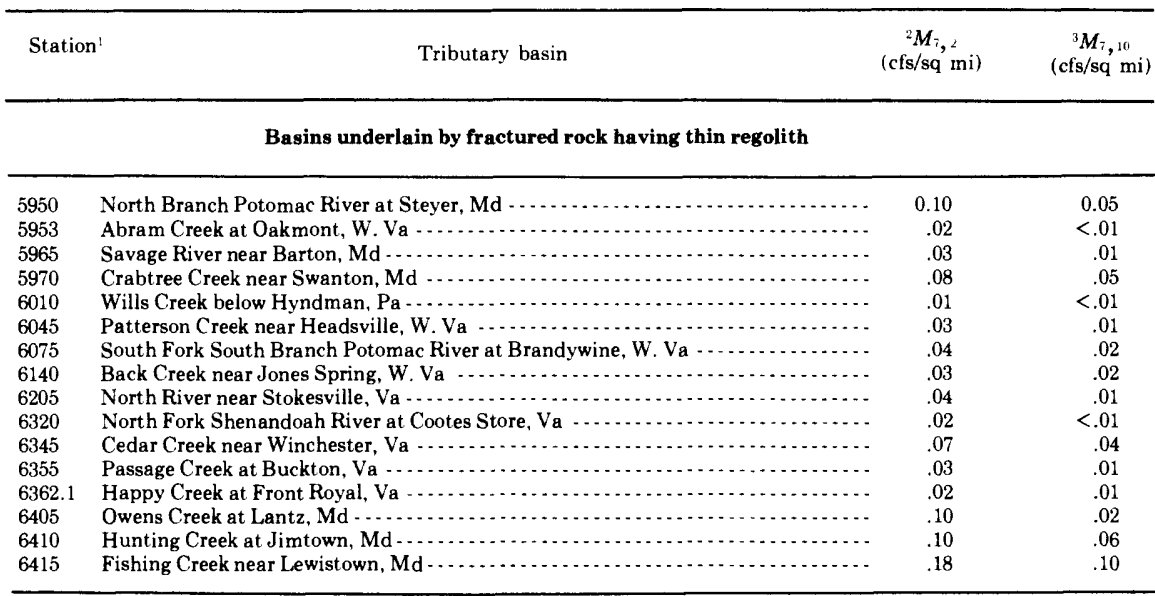

Basins underlain by fractured rock having thick regolith

\begin{tabular}{|c|c|c|c|}
\hline 6375 & Catoctin Creek near Middletown, Md & 0.04 & 0.01 \\
\hline 6390 & Monocacy River at Bridgeport, Md & .02 & .01 \\
\hline 6395 & Big Pipe Creek at Bruceville, Md & .18 & .07 \\
\hline 6425 & 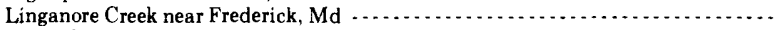 & .17 & .08 \\
\hline 6440 & Goose Creek near Leesburg, $\mathrm{Va}$ & .03 & .01 \\
\hline 6450 & Seneca Creek at Dawsonville, Md $\ldots \ldots$ & .21 & .05 \\
\hline 6460 & Difficult Run near Great Falls, Va $\ldots \ldots \ldots$ & .18 & .05 \\
\hline
\end{tabular}

Basins underlain by carbonate rock

\begin{tabular}{|c|c|c|c|}
\hline 6145 & Conococheague Creek at Fairview, Md & 0.17 & 0.09 \\
\hline 6150 & Opequon Creek near Berryville, Va $\ldots \ldots \ldots$ & .06 & .02 \\
\hline 6165 & Opequon Creek near Martinsburg, W. Va & .16 & .11 \\
\hline 6170 & Tuscarora Creek above Martinsburg, W. Va $\ldots$ & .15 & .07 \\
\hline 6195 & 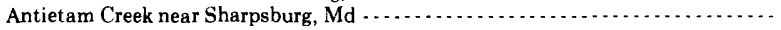 & .27 & .20 \\
\hline 6220 & 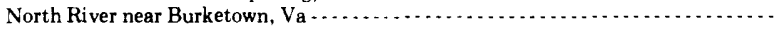 & .15 & .10 \\
\hline 6250 & Middle River near Grottoes, $\mathrm{Va}$ & .21 & .14 \\
\hline 6260 & South River near Waynesboro, Va & .23 & .18 \\
\hline 6285 & South Fork Shenandoah River near Lynnwood, Va & .20 & .14 \\
\hline 6310 & South Fork Shenandoah River at Front Royal, Va $\ldots \ldots$ & .20 & .15 \\
\hline 6330 & 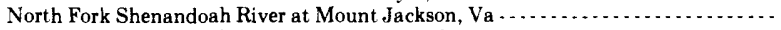 & .07 & .03 \\
\hline 6340 & North Fork Shenandoah River near Strasburg, Va & .13 & .08 \\
\hline 6365 & 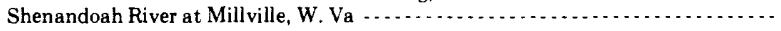 & .18 & .11 \\
\hline
\end{tabular}

${ }^{1}$ Stream-gaging station, U.S. Geological Survey.

${ }^{2}$ Minimum mean 7 -day low flow at 2 -year recurrence interval.

Minimum mean 7-day low flow at 10 -year recurrence interval.

for mean annual runoff and for $Q_{52}$ (taken in this report to approximate mean annual base runoff) are nearly proportional to drainage area, but low flow is far greater in the Appalachian Valley than in the remainder of the upper Potomac River basin. This greater low flow is due to the presence of carbonate rock, which underlies much of the Appalachian Valley but elsewhere is extensive only in the headwater regions of a few basins in the western part of the Valley and Ridge province and in the Piedmont province. The Appalachian Plateaus and most of the western Valley and Ridge province are underlain principally by shale and 
sandstone, and the Blue Ridge and Piedmont, principally by crystalline rock, shale, and sandstone.

The contrast between the areal distribution of mean annual discharge and base runoff, on the one hand, and of low flow, on the other, is illustrated by figure 10 . For a given tributary basin, mean annual discharge $(Q)$ bears about the same relation to the discharge of the entire upper Potomac River basin as the area of the tributary basin bears to the area of the entire basin. For example, basin 7 in figure 10 (South Fork Shenandoah River at Front Royal, Va.) drains 14 percent of the area of the upper Potomac river basin and provides 14 percent of its mean annual discharge. The chief exception to this statement, basin 1 (North Branch Potomac River near Cumberland, Md.), drains a region

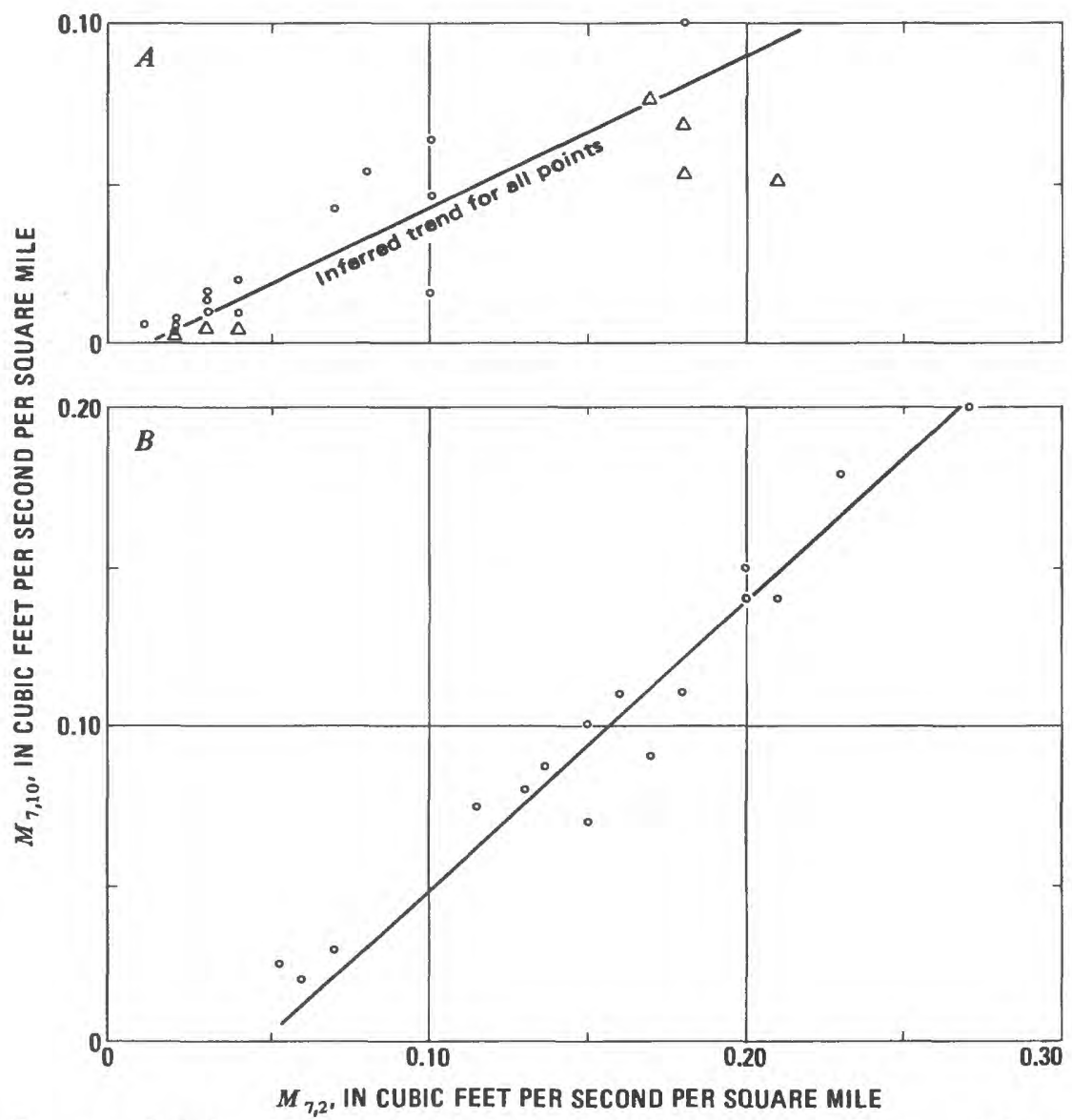

Figure 9.-Relation of $M_{7,10}$ to $M_{7,2}$ in three geohydrologic terranes. $A$, Basins underlain by fractured rock having thin regolith (circles); basins underlain by fractured rock having thick regolith (triangles). $B$, Basins underlain largely by carbonate rock. 
of relatively high precipitation and provides proportionately more runoff per unit area as a result. Mean annual base runoff $\left(Q_{52}\right)$ is also

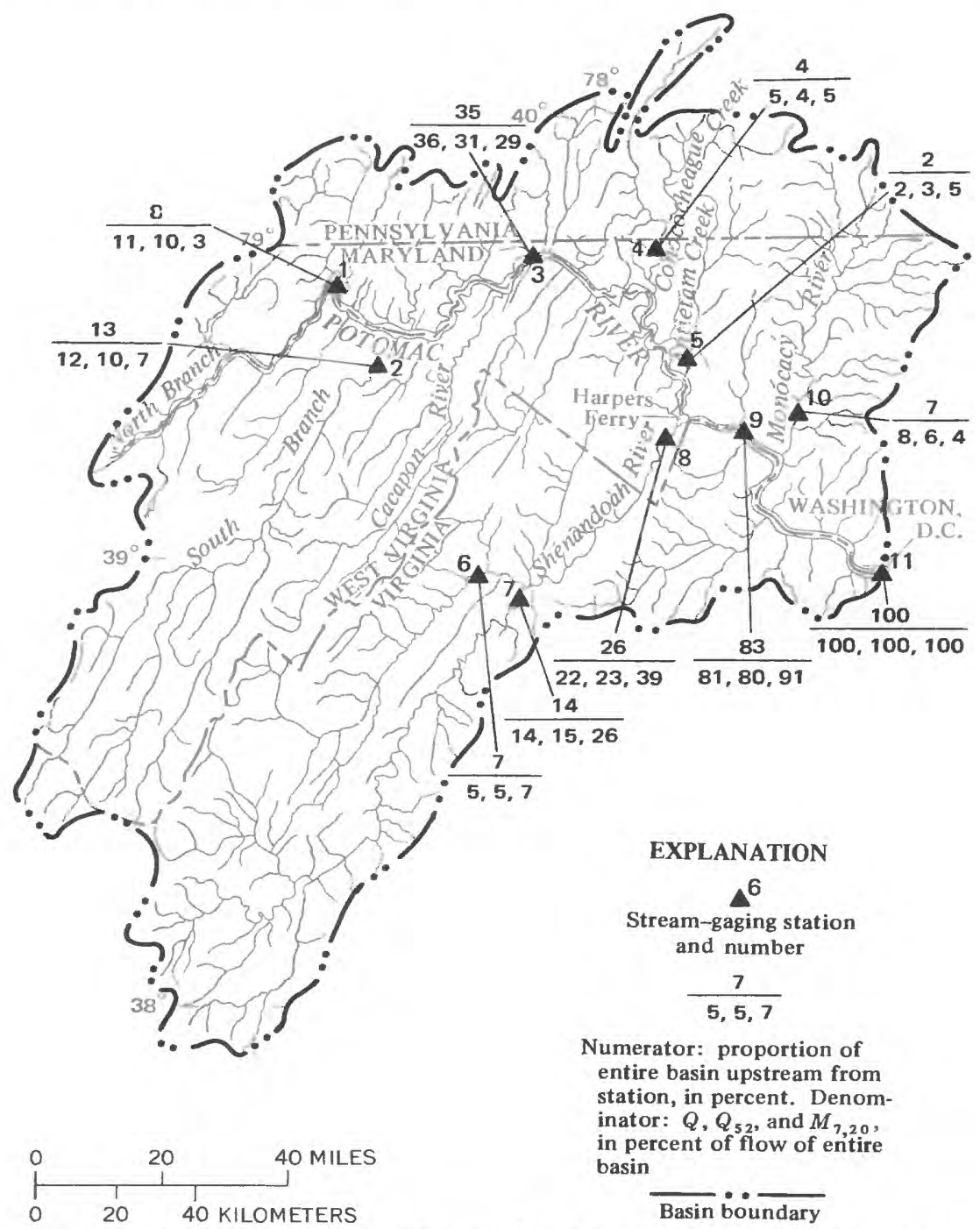

FiguRE 10.-Areal changes in selected streamflow characteristics. Gaging stations are as follows: 1, North Branch Potomac River near Cumberland, Md.; 2, South Branch Potomac River near Springfield, W. Va.; 3, Potomac River at Hancock, Md.; 4, Conococheague Creek at Fairview, Md.; 5, Antietam Creek near Sharpsburg, Md.; 6, North Fork Shenandoah River near Strasburg, Va.; 7, South Fork Shenandoah River at Front Royal, Va.; 8, Shenandoah River at Millville, W. Va.; 9, Potomac River at Point of Rocks, Md.; 10, Monocacy River at Jug Bridge, near Frederick, Md.; 11, Potomac River near Washington, D.C. 
approximately proportional to drainage area in most tributary basins. For example, basin 7 yields 15 percent of the base runoff of the upper Potomac basin from 14 percent of the drainage area, and basin 1 yields 10 percent from 8 percent of the drainage area. (The apparent proportional increase in base runoff for basin 1 probably reflects releases of water from Savage Reservoir.)

At low flow, however, the relative contributions of some tributary basins are much greater, and those of others are much less. Thus, the mean 7-day minimum low flow at a 20 -year recurrence interval $\left(M_{7,20}\right)$ is relatively low in tributary basins underlain by shale and sandstone (basins 1 and 2, fig. 10) or by crystalline rock (basin 10). It is relatively high in those underlain largely by carbonate rock: basin 7 provides 26 percent of the $M_{7,20}$ flow of the entire basin from 14 percent of its area, and basin 5 provides 5 percent of the flow from only 2 percent of the area. (This high percentage of low flow' is partly due to regulation, but the general conclusion is unaffected.) This restriction of many of the more productive parts of the Potomac basin (in terms of low flow) to areas of carbonate rock is well shown by figure 11. As was noted in discussion of figure 10, the relatively high flow shown for tributary basins in the northwestern part of the Potomac basin is attributed to augmentation of low flow by water released from Savage Reservoir.

\section{GROUND WATER AND WATER MANAGEMENT}

The ground-water resource has not been developed systematically in the upper Potomac River basin, and the potential significance of ground-water management has not been examined in detail. Among aspects of water management that warrant examination are (1) availability of large ground-water supplies, (2) manipulation of groundwater storage through artificial recharge, and (3) augmentation of the low flow of streams with ground water.

Use of any of these methods of management would require favorable geohydrologic conditions (suitable rocks in situations favorable for recharge of the ground-water reservoir). In the upper Potomac River basin, fresh ground water, recharged naturally from precipitation on the land surface, is stored in and moved through a zone of rock whose thickness ranges from a few hundred feet or less in much of the mountainous country to as much as 1,000 feet in carbonate rock in parts of the Appalachian Valley. Small ground-water supplies-from 1 gallon per minute or less to several gallons per minute-can be obtained from springs or wells nearly everywhere in the upper Potomac River basin. Large supplies-from several tens to several hundreds of gallons per minute-have been developed only locally, however. Artificial recharge and low-flow augmentation have not been attempted in the basin. 


\section{LARGE GROUND-WATER SUPPLIES}

Identification of areas capable of yielding large supplies of ground water is based on two criteria discussed earlier in this report: (1) high transmissivity of aquifers and (2) high base runoff (ground-water runoff to streams). High transmissivity helps to ensure that water in an aquifer can be developed at reasonable cost; the base runoff provides a

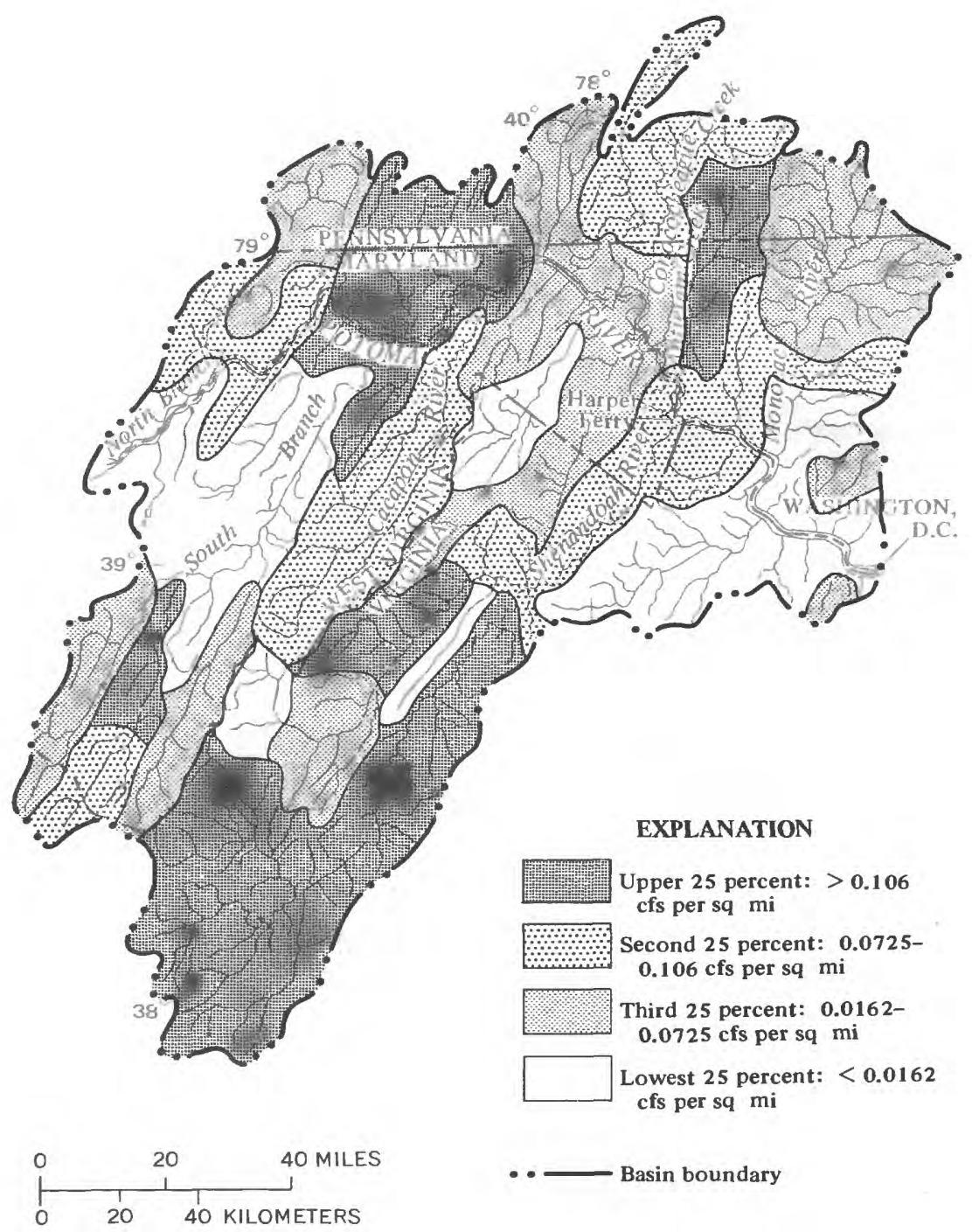

Figure 11.-Ranking of tributary basins in terms of 7-day minimum average streamflow at 20-year recurrence interval $\left(M_{7},{ }_{20}\right)$. Data summarized and map prepared by E. D. Cobb and J. F. Bailey. 
rough index of the potential sustained ground-water yield of an aquifer or basin. Although the relation between base runoff and potential ground-water yield to wells is not simple (Olmsted and Hely, 1962, p. A21), some predictions are nevertheless possible: large water supplies are unlikely to be found in rocks that yield low base runoff but are probably available, at least locally, in rocks that yield high base runoff. Thus, study of base runoff provides an index of ground-water availability that can be used to delineate regions of high potential availability.

Within a region of high potential availability (in one of the more productive tributary basins, for example) the base runoff is derived from small areas underlain by fairly productive water-bearing rocks and large areas underlain by much less productive rocks. The favorable areas, generally delineated through study of base runoff, must be further defined by geologic mapping, by detailed study of areal differences in streamflow, and by investigation of wells and springs. This approach to outlining areas favorable for development of large ground-water supplies reflects the meager information available in the upper Potomac River basin on wells of high yield. Only a few wells in the basin were drilled for the purpose of obtaining large supplies, and records of wells of low yield are of little value in evaluating the maximum quantities of water available to wells.

Evidence provided by base runoff and by transmissivity values, which suggests that carbonate rock is the most favorable terrane in the basin for the development of large ground-water supplies, is confirmed by the few well records available and by the occurrence of large springs. Although a few highly productive wells have been drilled in other types of rock, most of the larger capacity wells are in carbonate rock. And nearly all the large springs in the basin drain carbonate rock.

The histograms in figure 12 illustrate the marked difference between the carbonate and noncarbonate rocks, in terms of large-capacity wells. The frequencies of specific-capacity values are roughly comparable throughout most of the range of values. At values greater than $10 \mathrm{gpm}$ per foot of drawdown, however, the frequency of wells in carbonate rock is 10 times that in noncarbonate rock.

Figure 13 shows the distribution of major areas of carbonate rock in the upper Potomac River basin. The principal area is in the Appalachian Valley, from Chambersburg, Pa., to Waynesboro, Va. Smaller areas are in the Piedmont province in Maryland and Virginia and in the headwaters regions of several tributary basins in the Valley and Ridge province in Pennsylvania, Maryland, and West Virginia. Numerous small areas of carbonate rock are not shown in figure 13.

In the Potomac basin, the center of the Appalachian Valley is underlain by shale. The shale occupies the axial region of a large synclinal fold, and older, carbonate rocks are exposed in belts along the sides of this belt of shale (fig. 13). Because the limbs of the large fold have been 
folded and faulted and because the strata of carbonate rock are hundreds to thousands of feet thick, extensive parts of the valley floor are underlain by carbonate rock. In most of the rest of the basin, carbonate-

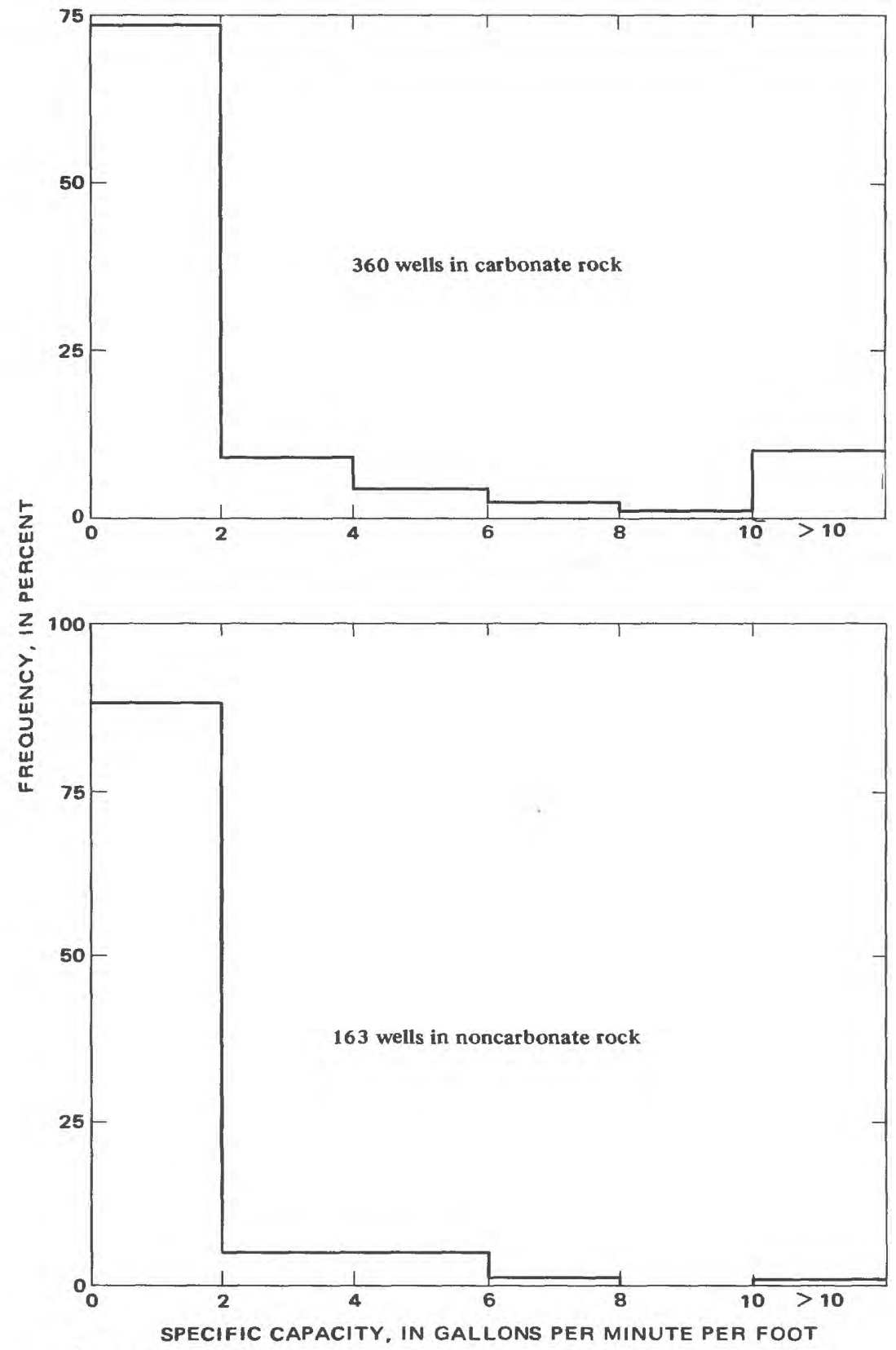

Figure 12.-Frequency distribution of values of specific capacity of wells. 
rock strata are thinner and are steeply dipping, so relatively small areas are underlain by these rocks.

The successful construction of large-capacity wells at several localities in the Appalachian Valley shows that large ground-water supplies can be developed locally. A total of about 25 million gallons per day has been pumped from wells in three industrial areas-Waynesboro, Grottoes, and Elkton, Va.-near the southeast side of the valley (fig. 13). Supplies of similar magnitude may be

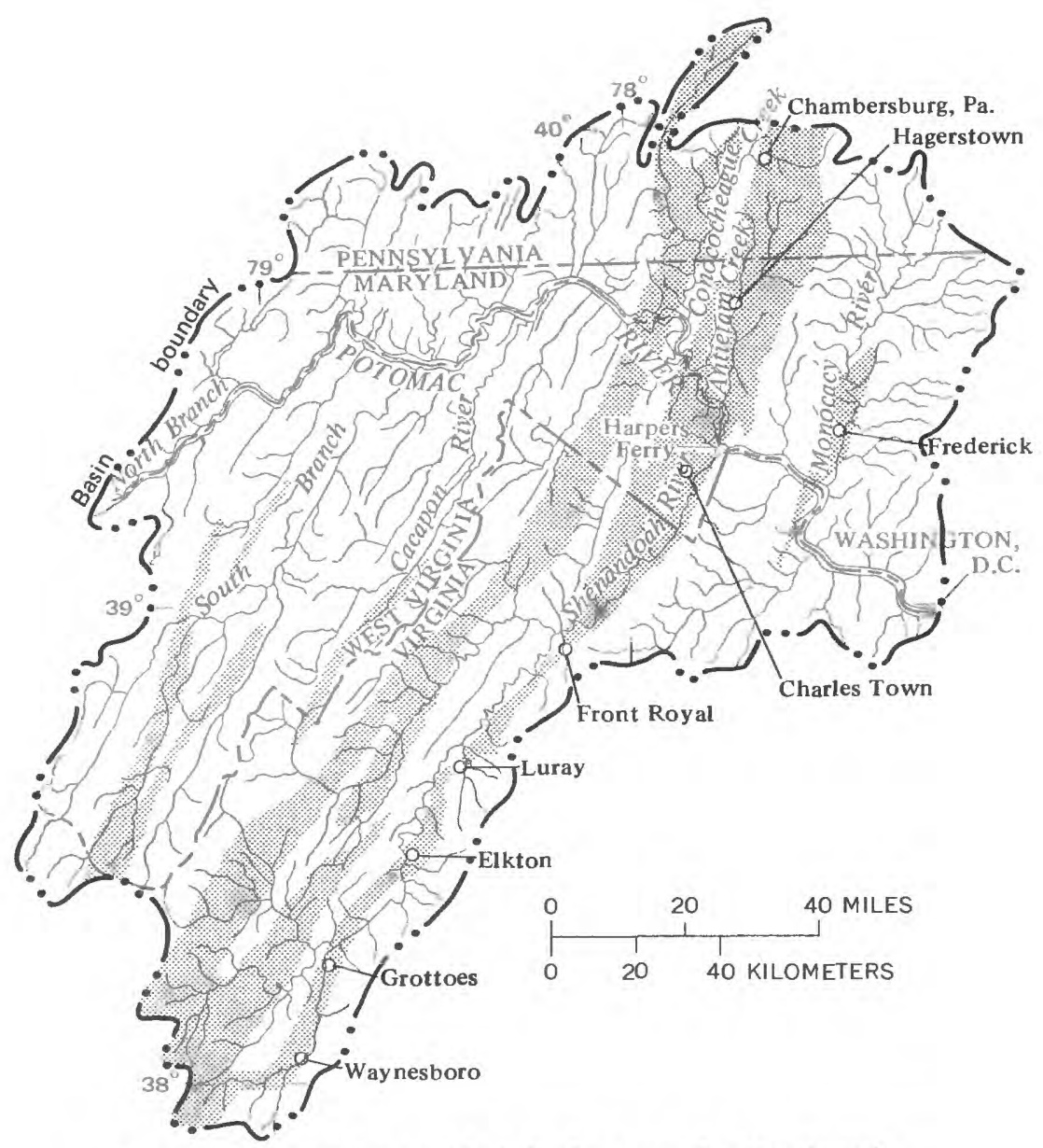

Figure 13.-Principal areas (shaded) of outcrop of carbonate rock. 
available at other places, but reconnaissance and test drilling will be required to find favorable places for this development.

Low water-table gradients, shown by the wide spacing of contour lines on the water table (pl. 1), indicate that the carbonate rock in the valley floor is relatively permeable over extensive areas. The largest such area covers the east half of the valley and extends from the vicinity of Chambersburg, Pa., through Hagerstown, Md., and Charles Town, W. Va., to Front Royal, Va. (fig. 13). Smaller areas along the southeast side of the lowland are at Luray, Va., and farther southwest. The belt of carbonate rock on the northwest side of the lowland is also characterized by relatively low water-table gradients along much of its length. All these areas should be favorable for prospecting. The water is highly localized because it is in solution features in the rock.

The Piedmont area of carbonate rock shown in figure 13 is underlain in Maryland by tightly folded limestone. In both Maryland and Virginia, limestone conglomerate lies along part of the west edge of the Piedmont lowland. Much smaller areas in the Piedmont, not shown in figure 13 , are underlain by marble.

\section{MANIPULATION OF GROUND-WATER STORAGE}

In the upper Potomac River basin, artificial recharge is probably most practicable and of greatest potential value in areas of heavy ground-water development, where cones of depression have formed as a result of long-term pumping. Heavy pumping causes these cones to grow until they reduce natural discharge sufficiently to maintain them in a stable form, or until recharge is induced by the pumping, or until pumping is reduced. Artificial recharge would help stabilize the cones of depression or reduce their extent and depth; thus, smaller areas would be affected, and the cost of pumping reduced. The presence of these cones of depression would facilitate artifical recharge in areas where it is most needed.

Streamflow would be the preferred source of water for artificial recharge. Because flow is greatest in early spring, when the discharge of most streams in the basin exceeds all downstream uses, artificial recharge could be done most effectively then. At most places, recharge could best be done through wells or pits.

The area near Grottoes, Va., may be one where artificial recharge could be effectively used. Pumping by industry and for public supply amounts to about 8 million gallons per day. The water level in an observation well on a slope about 1 mile east of the community has been as much as 70 feet below the level of the Shenandoah River, and deep water levels have been measured in other wells in this area (Gathright and Willson, 1968, p. 20-21).

A special type of artificial recharge, in which the disadvantage of seasonal availability of surplus stream water is overcome, may even- 
tually prove suitable for use in parts of the upper Potomac River basin. This method is the disposal of treated sewage water on the land surface by spray irrigation. This type of disposal has aroused wide interest in recent years, and it is being investigated in a variety of terranes. Studies in progress at State University, Pa. (Parizek, 1971), where disposal is to the regolith on carbonate rock, are of particular interest for their bearing on possible use of the method in parts of the Potomac River basin.

Spray irrigation disposes of treated waste water that now is commonly dumped into streams where nutrients dissolved in the waste (especially ions and compounds of nitrogen and phosphorous) promote extensive algal growth. Spraying this bacteriologically pure water on the land surface leads to temporary storage of water on and in the soil, before removal by evapotranspiration and by percolation to the water table. Part of the purpose of the method is removal of much or most of the nutrient load in the water by plants. Where this goal is met, spray irrigation leads to an increase in ground-water recharge and a reduction in nutrient load of the streams. An increase in dissolved load of the local ground water, which will eventually reach the streams, is a possible consequence of spray irrigation with sewage water.

Rates of spraying to obtain the optimum combination of groundwater recharge and nutrient removal by plants, the feasibility of winter spraying (when plants are quiescent and nutrient removal is greatly reduced), and the effect of the disposal on the quality of ground water and stream water are important subjects for programs to investigate the feasibility of disposal by spray irrigation. Geohydrologic information already available suggests that in the upper Potomac River basin this method of disposal is potentially most valuable east of the Blue Ridge and in parts of the Appalachian Valley, where the regolith is thickest. These areas also happen to be the most heavily settled parts of the basin, where the sewage-disposal problem is and will continue to be most pressing.

Artifical recharge would be more difficult and less effective in areas outside cones of depression. The water table is normally at its highest level during spring, when surface water is available in largest quantity and when the amount of underground space naturally available for the artificial storage of ground water is at its annual minimum. Moreover, the terrane most favorable for underground storage of water under natural conditions is carbonate rock beneath hills, where topography would make delivery of the water to recharge facilities difficult and expensive. The most favorable and practicable combination of topographic situation and rock type is at places in the Appalachian Valley where carbonate rock is exposed at the foot of the mountain slope and where water could be brought by pipe or ditch from a surface impoundment in a mountain valley. Other rocks in favorable topographic positions are much less promising for artificial recharge. 
Shale and tight sandstone contain relatively little storage space-less than 1 percent, on the average-and they have relatively low transmissivity. Thick apron and fan deposits of gravel cicur at several places along the lower slopes of mountains, notably along tıe west face of the Blue Ridge (Hack, 1965, p. 66-70). Where exposed by pits (manganese mines) and penetrated by wells, however, these deposits were commonly not water bearing, perhaps because of their high clay content.

Artificial recharge would be a side benefit of the construction of surface reservoirs. Impounding water behind a dam in a stream valley leads to storage of additional unseen water in the banks of the reservoir. Around a reservoir of even moderate area and depth, this process would result in a significant increase in ground-water storage. In crystalline rock, tight sandstone, and shale, increase in ground-water storage would probably be $1 / 2$ to 1 percent of the volume of the wedgelike mass of rock defined by the submerged stream bank and the old and new positions of the water table. In carbonate rock, it would be greater-perhaps as much as several percent of the volume of newly saturated rock. In considering this form of artificial recharge, however, note that this ground-water storage can be used advantageously only where a reservoir is drawn down periodically so that the ground water in bank storage drains out, emptying space that will be refilled when the reservoir level is raised again.

\section{LOW-FLOW AUGMENTATION}

In the upper Potomac River basin, the ground-water reservoir and the streams are interconnected to form a single water system. Water flowing through the ground feeds the streams at rates that depend on the amount of water in aquifer storage; for example, the rate is higher when the amount of water in storage (and, thus, the head difference in the direction of ground-water flow) is large than when it is small. Pumping water from the ground "short-circuits" this natural flow system. The pumping may make the water available for use at a convenient time and place, but it reduces the amount of water that will later drain naturally into the stream system from underground. Furthermore, the lowering of water level near the site of pumping may, near a stream, be accompanied or followed rather quickly by decrease in ground-water discharge into the stream, or it may lead to flow from the stream into the ground, as a result of the change in head. Removal of ground water thus reduces streamflow ultimately and, under some conditions, in the short term also. Near a stream, the timing of this effect depends on the local degree of interconnection of a stream and ground-water reservoir. The use of ground water does not normally increase the total yield of water from the basin system. (An exception to this last conclusion occurs where pumping lowers a water table that had been so near 
the land surface that the ground water was subject to evapotranspiration. Reduction in evapotranspiration, through pumping, is a net gain to the water supply of the basin.)

Despite these qualifications, the use of ground water to augment low streamflow for brief periods (perhaps a few weeks) is potentially a valuable tool in water management, and the availability of large undeveloped ground-water supplies at convenient places is an important element in considering possible alternative plans of management. Augmentation is feasible because, under favorable conditions, water removed from storage in late summer or early autumn will be replaced by recharge during the winter period of water surplus, and the local decrease in ground-water discharge to the stream is delayed and will be offset by high discharge to other parts of the stream during the season of surplus. Thus, successful use of ground water to augment low flow temporarily by pumping into a stream depends on finding places where adequate ground water is in storage but is not so close to the stream, nor the aquifer so effectively interconnected with it, that streamflow is reduced quickly as a result of the pumping.

Two sources of ground water in the upper Potomac River basin warrant consideration as possible sources of ground water for streamflow augmentation. These are alluvium, in valley bottoms and along the lower slopes of some mountains, and carbonate rocks, principally in the Appalachian Valley.

The valley bottoms are commonly narrow, so most alluvial deposits there are near the streams. Where an alluvial aquifer is fairly permeable, therefore, it probably has effective hydraulic connection with the stream. Test drilling in the Piedmont province in Maryland (Meyer and Beall, 1958) and in the Potomac River flood plain in Virginia showed that the alluvial deposits are typically thin and, because they contain large proportions of clay and silt, are relatively impermeable. Bedrock is exposed at many places in the channel of the Potomac River, in and east of the Blue Ridge, and in tributary streams in the Blue Ridge and Piedmont provinces. Hence alluvial deposits in the Blue Ridge-Piedmont region are probably generally too thin, too impermeable, and too restricted areally for the development of significant ground-water supplies without causing infiltration from the river. Test drilling in valley bottoms at several localities in the Valley and Ridge province in West Virginia showed the alluvial deposits to have a large content of silt and clay, which makes them relatively impermeable (W. A. Hobba, Jr., U.S. Geol. Survey oral commun., 1970).

The thickness and hydrologic properties of the alluvium that flanks and mantles the lower mountain slopes are poorly known. Data provided by pits (manganese mines) and a few wells suggest that the alluvium is commonly clay rich and not effective as an aquifer (although it is undoubtedly significant in the infiltration of precipita- 
tion and the transmission of water to the underlying rocks).

The carbonate rock of the Potomac River basin, on the other hand, is a potential source of ground-water supplies that could be used to augment low flow. A variety of data, already cited, show that the carbonate rock is the most favorable bedrock in the basin for the development of large water supplies; and these data, with the low ground-water gradients in much of the area of plate 1, show that the Appalachian Valley is the most favorable region in the basin for low-flow augmentation.

Test drilling is needed in the Appalachian Valley to locate parts of the region most favorable for the development of large ground-water supplies and to determine typical aquifer characteristics and boundary conditions in these areas. Most wells in the valley were not constructed to obtain the maximum yield, and there are large gaps in areal coverage provided by the wells. The effectiveness of interconnection between streams and the carbonate-rock aquifer is a critical boundary consideration because of possible effects of pumping on the flow of nearby streams or springs, which may already be used as sources of supply.

Augmentation of low streamflow by ground water is only one aspect of water management and any potential use of ground water for lowflow augmentation will have to be evaluated along with other potential uses of the water. Sites intended as sources of water for augmentation will generally have to be reserved from development of large industrial or municipal water supplies. The specific purpose of any augmentation project may influence the choice between water-supply and flowaugmentation alternatives in development at a given site. If the principal purpose of a project is protection of water quality through dilution of municipal or industrial waste effluents in a specific reach of stream, the project may require an upstream site or sites that have been set aside for this purpose. On the other hand, if the purpose is maintenance of flow for general downstream use, it may be practicable to set aside one or more sites at any place where large ground-water supplies are available but where development for industrial or municipal use is unlikely.

\section{CHEMICAL QUALITY OF THE GROUND WATER}

The dissolved load in ground water affects the suitability of the water for domestic, agricultural, and industrial purposes. Ground water provides the base flow of the streams and, hence, controls the chemical quality of the stream water much of the time. During the remainder of the time, the dissolved load in the stream water is much like that in the ground water, except for a lower concentration of constituents. Water in the upper Potomac River basin is typically of a calcium bicarbonate composition but has subordinate magnesium and sulfate. Areal differences in geology lead to areal and local differences in the relative 
proportions of these principal ions in the ground water. Because streams integrate water from their entire basins, they commonly present a better picture of average composition of dissolved solids than summaries of small numbers of chemical analsyes of ground water from the basins.

Figure 14 illustrates the regional pattern of composition of the dissolved load in stream water in the Upper Potomac River basin. In the Appalachian Plateaus (sta. 1 and part of the region upstream from sta. 2 , fig. 14), ground water that has flowed through coal mines has become an acidic sulfate water, with a high content of iron, manganese, and aluminum (sta. 1). Discharge of this acidic mine-drainage water to the surface governs water quality in much of North Branch Potomac River. By the time the water reaches Cumberland, Md. (sta. 2), however, the acid has been neutralized by the inflow of alkaline water; most of the iron, manganese, and aluminum has been precipitated, and the water has acquired a calcium sulfate composition. The addition of calcium bicarbonate water from the basin of South Branch Potomac River (sta. 3) leads to marked increase in bicarbonate and further decrease in sulfate in the main stream (sta. 4). Further increase in bicarbonate content results from inflow from the Appalachian Valley (sta. 5, 7, and 8). However, the largest of these contributions, from the Shenandoah Valley in Virginia and West Virginia (sta. 8), and inflow from the Piedmont province (sta. 9 and 10) combine to maintain the sulfate level in the Potomac River near Washington (sta. 11) at nearly the level observed upstream from the principal Appalachian Valley inflow (sta.6).

Although composition of dissolved load is a major part of the picture of chemical quality of the water, the dissolved-solids content is also important. The hardness of ground water is illustrated on a broad regional basis in figure 15. (Hardness, rather than the sum of dissolved solids, is used here as a criterion of concentration because hardness was determined in more water analyses than was the sum of dissolved solids.) The data show that hardness of the ground water ranges from low values in the Blue Ridge-Piedmont region to relatively high values in the Appalachian Valley, with intermediate levels in the Appalachian Plateaus and western Valley and Ridge regions. Hardness of water in the Potomac River reflects the influence of this regional pattern of ground-water hardness. The average hardness of Potomac water, as shown by the analyses available, decreases markedly after the river leaves the Appalachian Plateaus and flows across the western Valley and Ridge region; it increases in the reach crossing the Appalachian Valley and decreases again as the river crosses the Piedmont.

\section{CHEMICAL QUALITY AS RELATED TO LOW-FLOW AUGMENTATION}

The principal problems of the chemical quality of the ground water, as related to the potential for low-flow augmentation, are the presence 
of acidic mine-drainage water in the Appalachian Plateaus region; the natural occurrence, in some parts of the basin, of relatively high concentrations of such constituents as iron, sulfate, chloride, and hydrogen sulfide; and the widespread distribution, in some parts of the basin, of

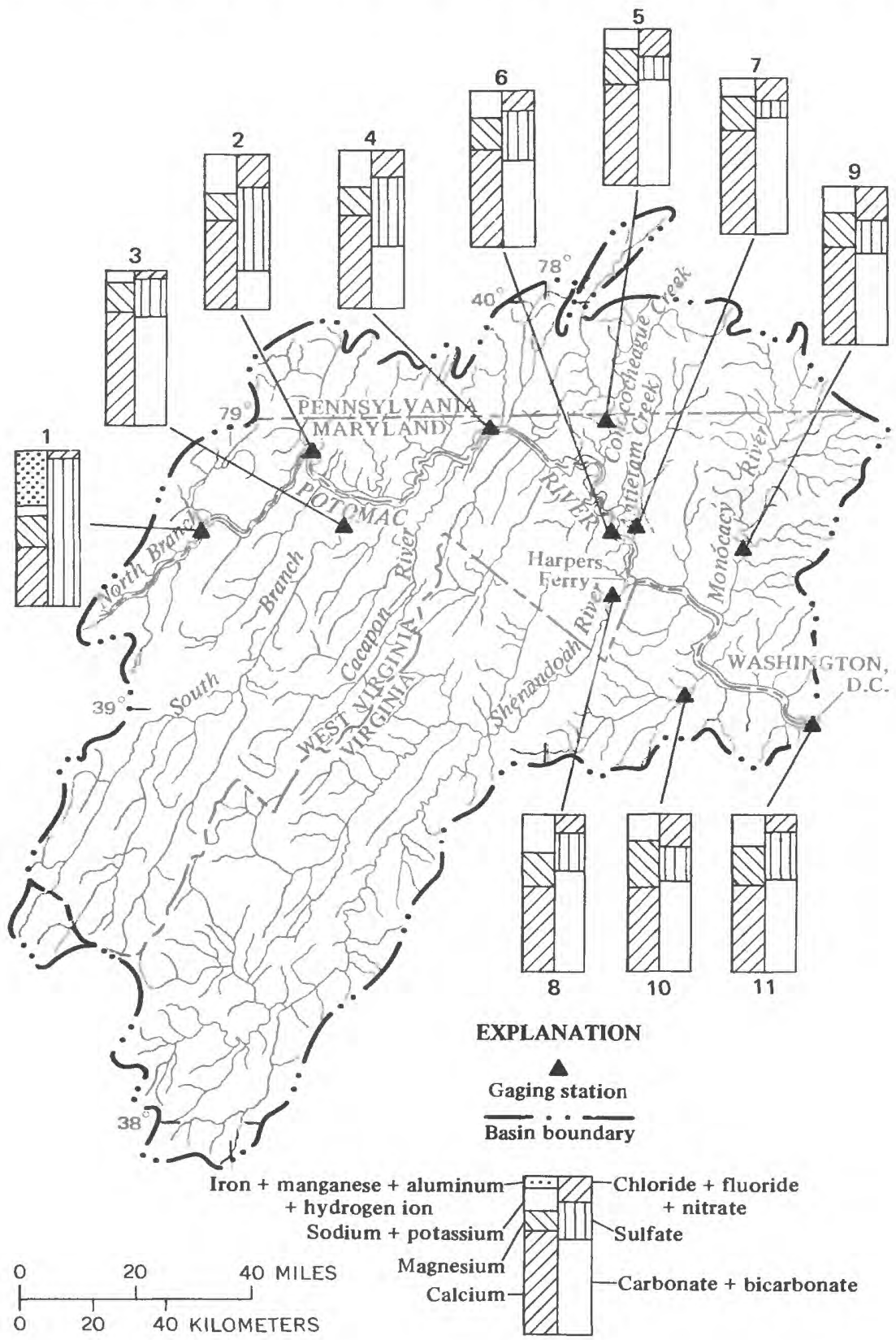


relatively high concentrations of nitrate, which are attributed to pollution.

\section{MINE-DRAINAGE WATER}

The breakdown of pyrite (iron sulfide) in and associated with coal, upon exposure to air and water by mining, leads to the formation of sulfuric acid. The acidic water is able to hold in solution high concentrations of iron, manganese, and aluminum. The resulting water is unsuitable for any use unless it is highly diluted by water unaffected by mine drainage.

Coal has been mined in this part of the Potomac River basin for about 150 years, and for much of this time streams have been degraded by the mine-drainage water. The problem has been aggravated in recent years as a result of increased coal production, and recent studies have shown (Clark, 1969, p. II-1) that water in part of North Branch Potomac River and in many of its tributaries fails to meet Maryland and West Virginia water-quality standards continuously or for much of the year. More than 40 miles of the North Branch above Luke, Md., and more than 100 miles of tributary streams are now virtually devoid of aquatic life.

Although acidic water is formed locally as a result of mining, and a few tributary streams contribute most of it, once in the stream the acid and high mineralization tend to persist for long distances despite some precipitation on the stream bed. Drainage from carbonate rock provides the most effective natural neutralization of the acidic water, but this type of rock is not abundant in the Appalachian Plateaus region. Effects of the mine drainage, therefore, persist far beyond the areas of mining. Study of records of specific conductance of water from the North Branch at Cumberland, Md., shows that the water is markedly less mineralized during and shortly after many flood peaks than during low flow. Clark (1969, p. V-31) noted, however, that "slugs" of water which moved downstream in August 1966 after heavy rains had high acidity ( $\mathrm{pH}$ values of 3.3 to 3.6 at Cumberland) and caused an extensive fish kill farther downstream. Similar sudden flushing of mine water, which is then carried far downstream, has caused large fish kills in Pennsylvania (Biesecker and George, 1966, p. 5). Clark (1969, p. VII-8) believed that full utilization of the proposed Bloomington Reservoir, planned for the North Branch near Barnum, W. Va., would not be attained unless a program for mine drainage was begun.

FIGURE 14.-Regional pattern of chemical composition of dissolved load in stream water.

Gaging stations are as follows: 1, North Branch Potomac River at Barnum, W. Va.;

2, North Branch Potomac River at Cumberland, Md,; 3, South Branch Potomac River near Springfield, W. Va.; 4, Potomac River at Hancock, Md.; 5, Conococheague Creek at Fairview, Md.; 6, Potomac River at Shepherdstown, W. Va.; 7, Antietam Creek near Sharpsburg, Md.; 8, Shenandoah River at Millville, W. Va.; 9, Monocacy River at Jug Bridge, near Frederick, Md.; 10, Goose Creek near Leesburg, Va.; 11, Potomac River near Washington, D.C. 

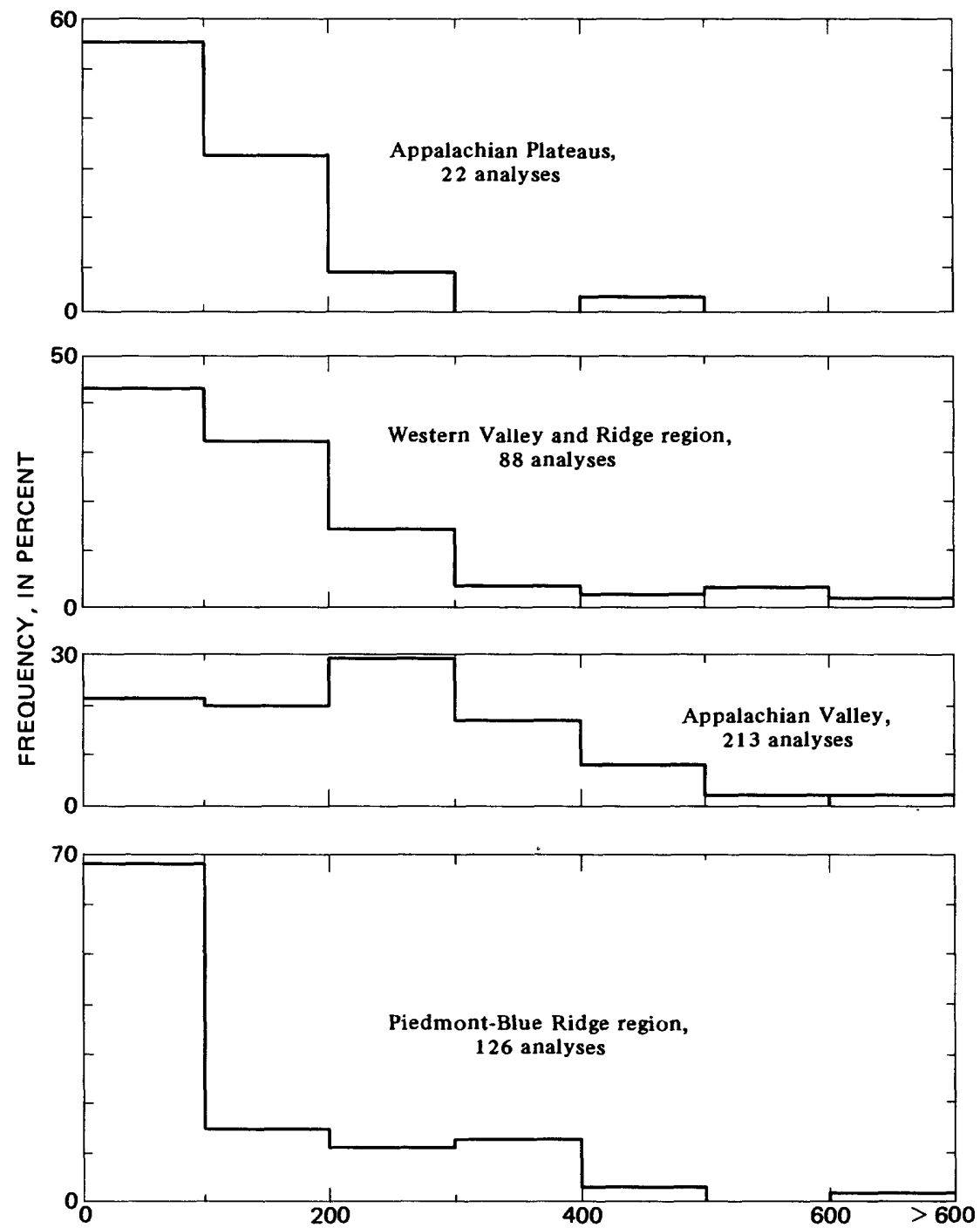

HARDNESS, AS $\mathrm{CaCO}_{3}$, IN MILLIGRAMS PER LITER

Figure 15.-Hardness of ground water. Data from Amsden and others (1954), Bieber (1961), Cady (1936), Dingman, Meyer, and Martin (1954), Johnston (1962), Meyer and Beall (1958), Slaughter and Darling (1962), and files of the U.S. Geological Survey.

Water quality will clearly be a problem in the North Branch Potomac River for a long time to come, both for use of the water in this region and for use downstream. If used for low-flow augmentation, the reservoir water could modify the highly mineralized acidic tributary water through dilution and through neutralization and other chemical reactions long before the acidic water reached distant downstream com- 
munities. But these changes would probably not occur rapidly enough to prevent damaging effects in reaches of the river near the Bloomington reservoir. The water might thus require treatment before its release for low-flow augmentation.

\section{MINERALIZED GROUND WATER}

In much of the upper Potomac River basin outside the relatively small areas of coal mining, the shallow ground water (within a few hundred feet of the surface) is of good quality and is suitable, with little or no treatment, for domestic, agricultural, and many industrial uses. At many places, however, particularly in the Appalachian Plateaus and the western part of the Valley and Ridge province, the shallow ground water contains troublesome concentrations of such constituents as iron, sulfate, and hydrogen sulfide and is hard. High hardness is common in the Appalachian Valley and in smaller areas of carbonate rock elsewhere in the basin. In these places, the water requires artificial softening for domestic and industrial use. However, use of this ground water for low-flow augmentation should prevent no special problems. The largest potential supplies of ground water for augmentation are in the Appalachian Valley, and the chief effect of that water on downstream water quality would be a temporary and probably small increase in hardness.

Deep ground water has been tapped by several wells in the western part of the Valley and Ridge province. This water, which is from below the near-surface zone that supplies most wells and springs and provides most of the base flow of the streams, has a high chloride content. (See, for example, Slaughter and Darling, 1962, p. 120-121, 138). When added to river water in small to moderate amounts, this high-chloride water would be diluted and thus rendered potable for downstream users, but it is less desirable for low-flow augmentation than fresher ground water available in other parts of the basin.

\section{NITRATE IN GROUND WATER IN THE APPALACHIAN VALLEY}

Nitrate is brought to the land surface in rain in small concentrations-probably 2 to $3 \mathrm{mg} / \mathrm{l}$ (milligrams per liter) at most. These concentrations may become somewhat increased as the water infiltrates the ground and part of it is lost by evapotranspiration. Nitrate is formed in the ground through oxidation of other nitrogen compounds produced by the decay of organic matter. Under natural conditions, however, soil bacteria and plants use most of the nitrogen that finds its way into the soil, and relatively little is carried into ground-water bodies. Numerous analyses of ground water from little-developed areas in the Potomac basin, both in the Appalachian Valley and elsewhere, indicate that the concentration of nitrate in ground water under natural conditions is less than 1 to $3 \mathrm{mg} / \mathrm{l}$. Larger concentrations of nitrate in 
ground water suggest contamination, because natural processes provide no ready explanation for such high concentrations.

Samples of ground water collected in the Appalachian Valley in Virginia in 1931 and 1933 (Cady, 1936, 1938) showed that at many places the ground water then contained several tens of milligrams of nitrate per liter of water. Later studies in the Appalachian Valley in West Virginia (Bieber, 1961) and in Maryland (Slaughter and Darling, 1962) showed similar occurrences and concentrations of nitrate. Similar contamination has been found in carbonate-rock terranes elsewhere. For example, Langmuir (1969, p. 73) observed that water from 10 percent of the domestic wells sampled in late 1967 in the Nittany Valley in Pennsylvania contained more than 45 parts per million $(45 \mathrm{mg} / \mathrm{l})$ nitrate. A concentration of nitrate greater than $45 \mathrm{mg} / \mathrm{l}$ can cause methemoglobinemia ("blue-baby disease") in infants. Lesser concentrations are not known to be harmful, but they may indicate pollution of water.

Plate 1 shows the areal distribution of 281 samples of ground water collected in the lowland part of the Appalachian Valley during February and March 1970 and the concentration of nitrate in these samples. Clustering of points-in Maryland and West Virginia near the Potomac River and in Virginia near Strasburg and Harrisonburg-is due to the fact that sampling was concentrated in areas of numerous wells. Thus, the areal distribution of the samples is not random; most samples are in areas of moderately dense agricultural population and urban development and therefore, they represent the parts of the lowland where contamination of ground water is most likely to be extensive. A smaller number of samples provides less dense coverage of the rest of the valley floor, including thinly settled parts, where contamination is less likely than where population is dense.

A striking aspect of nitrate contamination of ground water in the Appalachian Valley is the fact that it is so extensive in a predominantly rural environment, which is, by urban standards, very sparsely populated. Figure 16, which illustrates the frequency of nitrate values in samples collected in 1970, shows that most of the samples analyzed contained nitrate in much greater concentration than would be expected under natural conditions. Eighty percent of all the samples contained 5 $\mathrm{mg} / \mathrm{l}$ or more nitrate.

In many groups of samples collected in small areas there are several nitrate values lower than $3 \mathrm{mg} / \mathrm{l}$, many values in the range from 10 to 30 $\mathrm{mg} / \mathrm{l}$, and several higher than $30 \mathrm{mg} / \mathrm{l}$. This wide range in concentration in small areas probably reflects the presence of local, or "point," sources of contamination, from which the concentrations decrease downgradient in the direction of ground-water flow. Likely "point" sources include septic tanks, barnyards, feedlots for cattle and poultry, and processing plants for meat and poultry. Because the soil is thin on 


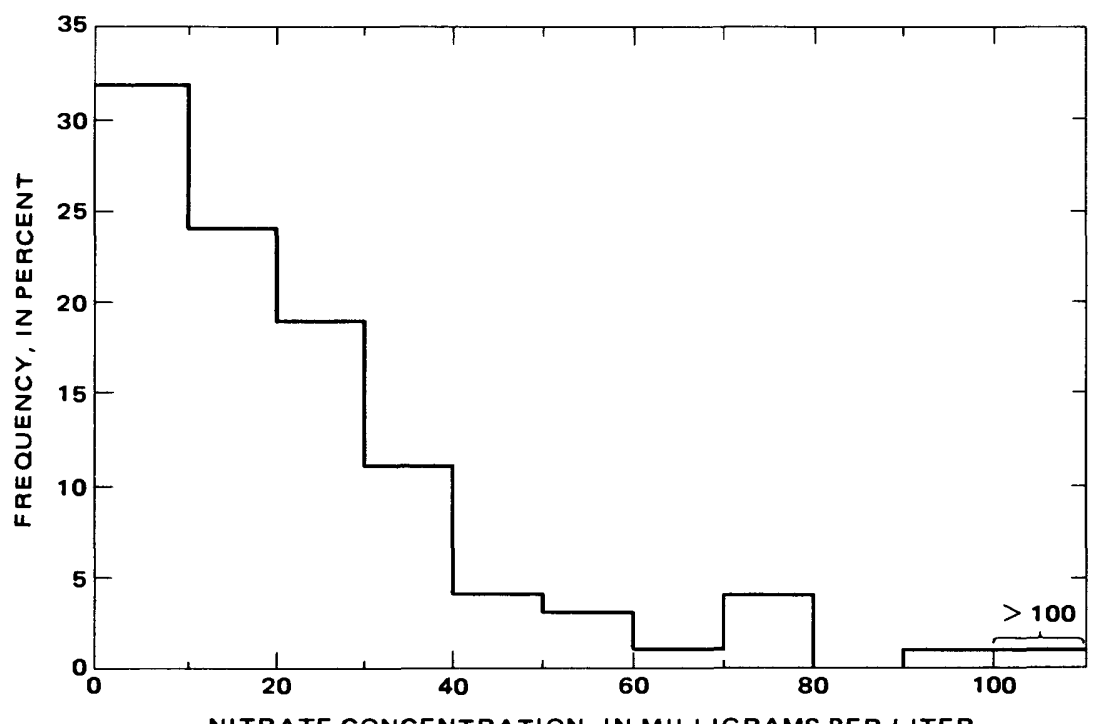

Figure 16.-Frequency distribution of the concentration of nitrate in 281 samples of ground water from the Appalachian Valley, February and March 1970.

much of the valley floor and the openings in the rock are fairly large, water infiltrating the surface, especially in depressions, is likely to enter the rock rapidly, without much filtration by the soil.

The lower nitrate concentrations are probably due to one of several causes; lower levels of contamination, dispersion of the contaminant during ground-water flow, or dilution by less contaminated water.

Almost all the part of the valley floor that is underlain by carbonate rock is cleared and in cultivation, and part of the nitrate in the ground water may be derived from farm fertilizer. Given the thin soil cover, even such a dispersed source of nitrate as fertilizer may be able to contaminate the ground water.

The concentration of nitrate in most Appalachian Valley stream samples in the Potomac River basin is higher than the expected background value of 1 to $3 \mathrm{mg} / \mathrm{l}$; in many samples it is 5 to more than 10 $\mathrm{mg} / \mathrm{l}$. Part of the nitrate load in the streams is provided by sewage and by drainage from feedlots, barnyards, and other sources of contaminated surface runoff, but part of it is undoubtedly provided by ground-water runoff.

All these data indicate that the nitrate content of ground water in the valley averages several milligrams per liter and reaches 40 to more than $50 \mathrm{mg} / \mathrm{l}$ in many local areas. If the ground water were used for low-flow augmentation, even the higher nitrate concentrations should not be enough, of themselves, to endanger downstream users because the water used would be diluted by the remainder of the streamflow. 
However, by the time any extensive use of ground water for streamflow augmentation is implemented, contamination by nitrate or other contaminants may have reached more serious levels. For this reason, any further investigation of the potential for low-flow augmentation ideally would include careful study of contamination of the ground water. The Appalachian Valley and the Piedmont province, the most heavily settled parts of the upper Potomac River basin, are the parts of the basin most susceptible to widespread contamination of ground water. With respect to augmentation of streamflow, the Appalachian Valley is the more significant because it would provide most of the ground water available for augmentation.

\section{REFERENCES}

American Society of Civil Engineers, 1949, Hydrology handbook: Am. Soc. Civil Engineers, Manual of Engineering Practice No. 28, 184 p.

Amsden, T. W., Overbeck, R. M., and Martin, R. O. R., 1954, Geology and water resources of Garrett County [Maryland]: Maryland Dept. Geology, Mines and Water Resources Bull. 13, 349 p.

Bieber, P.P., 1961, Ground-water features of Berkeley and Jefferson Counties, West Virginia: West Virginia Geol. Survey Bull. 21, $81 \mathrm{p}$.

Biesecker, J. E., and George, J. R., 1966, Stream quality in Appalachia as related to coalmine drainage, 1965: U.S. Geol. Survey Circ. 526, 27 p.

Cady, R. C., 1936, Ground-water resources of the Shenandoah Valley, Virginia: Virginia Geol. Survey Bull. 45, 137 p.

1938, Ground-water resources of northern Virginia: Virginia Geol. Survey Bull. 50, $200 \mathrm{p}$.

Clark, L. J., 1969, Mine drainage in the North Branch Potomac River basin: Environmental Protection Agency, Chesapeake Tech. Support Lab., Tech. Rept. 13.

Connor, J. G., and Schroeder, M. E., 1957, Chemical and physical character of surface waters of Virginia, 1948-1951: Virginia Div. Water Resources Plan. Bull. 20, 107 p.

Dingman, R. J., Meyer, Gerald, and Martin, R. O. R., 1954, The water resources of Howard and Montgomery Counties [Maryland]: Maryland Dept. Geology, Mines and Water Resources Bull. 14, $260 \mathrm{p}$.

Doll, W. L., Meyer, Gerald, and Archer, R. J., 1963, Water resources of West Virginia: West Virginia Dept. Nat. Resources, Div. Water Resources, 134 p.

Ferris, J. G., Knowles, D. B., Brown, R. H., and Stallman, R. W., 1962, Theory of aquifer tests: U.S. Geol. Survey Water-Supply Paper 1536-E, p. 69-174.

Gathright, T. M., and Willson, R. G., 1968, Ground-water fluctuations in Virginia: Virginia Minerals, v. 14 , no. 3 , p. 17-27.

Grundy, F., 1951, The ground-water depletion curve, its construction and uses: Internat. Assoc. Sci. Hydrology Pub. 33, p. 213-217.

Hack, J. T., 1965, Geomorphology of the Shenandoah Valley, Virginia and West Virginia, and origin of the residual ore deposits: U.S. Geol. Survey Prof. Paper 484, 84 p.

Hobba, W. J., Friel, E. A., and Chisholm, J. L., 1973, Water resources of the Potomac River basin, West Virginia: West Virginia Geol. and Econ. Survey River Basin Bull 3 (in press).

Horton, R. E., 1933, The role of infiltration in the hydrologic cycle: Am. Geophys. Union Trans., v. 14, p. 446-460.

Jacob, C. E., 1943, Correlation of ground-water levels and precipitation on Long Island, New York: Am. Geophys. Union Trans., pt. 2, p. 564-573. 
Johnston, P. M., 1962, Geology and ground-water resources of the Fairfax quadrangle, Virginia: U.S. Geol. Survey Water-Supply Paper 1539-L, 61 p.

Johnston, P. M., Pollock, S. J., and Weist, W. G., Jr., 1962, Ground-water resources of the Potomac River basin, app. G in Potomac River basin report: U.S. Army Corps of Engineers, U.S. Army Engineer District, Baltimore, Md.

Kapustka, S. F., 1957, Chemical and physical character of surface waters of Virginia, 1954-1956: Virginia Div. Water Resources Bull. 22, 161 p.

Langmuir, Donald, 1969, The chemistry of ground and surface waters in Nittany Valley [Pennsylvania]: Pennsylvania State Univ., Earth and Mineral Science, June, p. 73-74.

Maryland Geological Survey, 1968, Geologic map of Maryland: Maryland Geol. Survey, scale 1:250,000.

Meyer, Gerald, 1960, Chemical composition of fresh ground water in West Virginia: West Virginia Acad. Sci. Proc., v. 32, p. 162-166.

Meyer, Gerald, and Beall, R. M., 1958, The water resources of Carroll and Frederick Counties [Maryland]: Maryland Dept. Geology, Mines and Water Resources Bull. 22, $355 \mathrm{p}$.

Nutter, L. J., 1973, Hydrogeology of the carbonate rocks, Frederick and Hagerstown Valleys [Maryland]: Maryland Geol. Survey Rept. Inv. 19 (in press).

Nutter, L. J., and Otton, E. G., 1969, Ground-water occurrence in the Maryland Piedmont: Maryland Geol. Survey Rept. Inv. 10, 56 p.

Olmsted, F. H., and Hely, A. G., 1962, Relation between ground water and surface water in Brandywine Creek basin, Pennsylvania: U.S. Geol. Survey Prof. Paper 417-A, 21 p.

Pardé, Maurice, 1955, Fleuves et rivières: Paris, Librairie Armand Colin, 3d ed., 223 p.

Parizek, R. R., 1971, Waste water renovation and conservation project, in Parizek, R. R., White, W. B., and Langmuir, Donald, Hydrogeology and geochemistry of folded and faulted carbonate rocks of the Central Appalachian type and related land-use problems: Geol. Soc. America Guidebook, p. 153-170.

Pennsylvania Topographic and Geologic Survey, 1960, Geologic map of Pennsylvania: Pennsylvania Topog. and Geol. Survey, scale 1:250,000.

Riggs, H. C., 1964, The base-flow recession curve as an indicator of ground water: Internat. Assoc. Sci. Hydrology Pub. 63, p. 352-363.

Riggs, H. C., and Hanson, R. E., 1969, Seasonal low-flow forecasting, in Hydrological Forecasting: World Meteorolog. Organization, Tech. Note 92.

Rorabaugh, M. I., 1960, Use of water levels in estimating aquifer constants in a finite aquifer: Internat. Assoc. Sci. Hydrology Pub. 52, p. 314-323.

1964, Estimating changes in bank storage and ground-water contribution to streamflow: Internat. Assoc. Sci. Hydrology Pub. 63, p. 432-441.

Rorabaugh, M. I., and Simons, W. D., 1966, Exploration of methods of relating ground water to surface water, Columbia River basin-Second phase: U.S. Geol. Survey open-file rept., $62 \mathrm{p}$.

Slaughter, T. H., and Darling, J. M., 1962, The water resources of Allegany and Washington Countie [Maryland]: Maryland Dept. Geology, Mines and Water Resources Bull. 24, 408 p.

Snyder, F. F., 1939, A conception of runoff-phenomena: Am. Geophys. Union Trans., v. 20 , p. $725-738$.

Stiff, H. A., Jr., 1951, The interpretation of chemical water analysis by means of patterns: Jour. Petroleum Technology, v. 3, no. 10, sec. 1, p. 15-16; sec. 2 , p. 3.

Theis, C. V., 1935, Relation between the lowering of the piezometric surface and the rate and duration of discharge of a well using ground-water storage: Am. Geophys. Union Trans., pt. 2, p. 519-524. 
Theis, C. V., Brown, R. H., and Meyer, R. R., 1963, Estimating the transmissibility of aquifers from the specific capacity of wells in Bentall, Ray (compiler), Methods of determining permeability, transmissibility and drawdown: U.S. Geol. Survey WaterSupply Paper 1536-I, p. 331-341.

Thomas, J. D., 1966, Chemical quality reconnaissance of water of Maryland streams: Maryland Geol. Survey Rept. Inv. 5, 61 p.

Thornthwaite, C. W., and Mather, J. R., 1955, The water budget and its use in irrigation: U.S. Dept. Agriculture, Yearbook of Agriculture, 1955, p. 346-358.

Trainer, F. W., 1969a, Drainage density as an indicator of base flow in part of the Potomac River basin, in Geological Survey research 1969: U.S. Geol. Survey Prof. Paper 650-C, p. C177-C183.

1969b, Precipitation and base runoff, Big Pipe Creek basin, Maryland, in Geological Survey research 1969: U.S. Geol. Survey Prof. Paper 650-D, p. D222-D227.

U.S. Environmental Data Service, 1966-68, Climatological data [Maryland, Pennsylvania, Virginia, and West Virginia]: Environmental Data Service, U.S. Dept. Commerce.

U.S. Geological Survey, 1952, Surface-water supply of the United States, 1949; pt. 1, North Atlantic slope basins: U.S. Geol. Survey Water-Supply Paper 1141, 745 p. 1960, Quality of surface waters of the United States, 1956; pts. 1-4, North Atlantic slope basins to St. Lawrence River basin: U.S. Geol. Survey Water-Supply Paper $1450,603 \mathrm{p}$.

1967, Quality of surface waters of the United States, 1961; pts. 1 and 2, North Atlantic slope basins and south Atlantic slope and eastern Gulf of Mexico basins: U.S. Geol. Survey Water-Supply Paper 1881, 412 p.

U.S. Weather Bureau, 1947-65, Climatological data [Maryland, Pennsylania, Virginia, and West Virginia]: U.S. Weather Bureau, U.S. Dept. of Commerce.

Virginia Division of Mineral Resources, 1963, Geologic map of Virginia: Virginia Div. Mineral Resources, scale 1:500,000.

Virginia Division of Water Resources, 1960, Chemical character of surface waters of Virginia, August 1958-Feburary 1960: Virginia Div. Water Resources Plan. Bull. 23, $59 \mathrm{p}$.

Ward, R. C., 1967, Principles of hydrology: London, McGraw-Hill Book Co., 403 p.

West Virginia Geological and Economic Survey, 1968, Geologic map of West Virginia: West Virginia Geol. and Econ. Survey, scale 1:250,000.

4 U.S. GOVERNMENT PRINTING OFFICE: $19750-585-473 / 80$ 


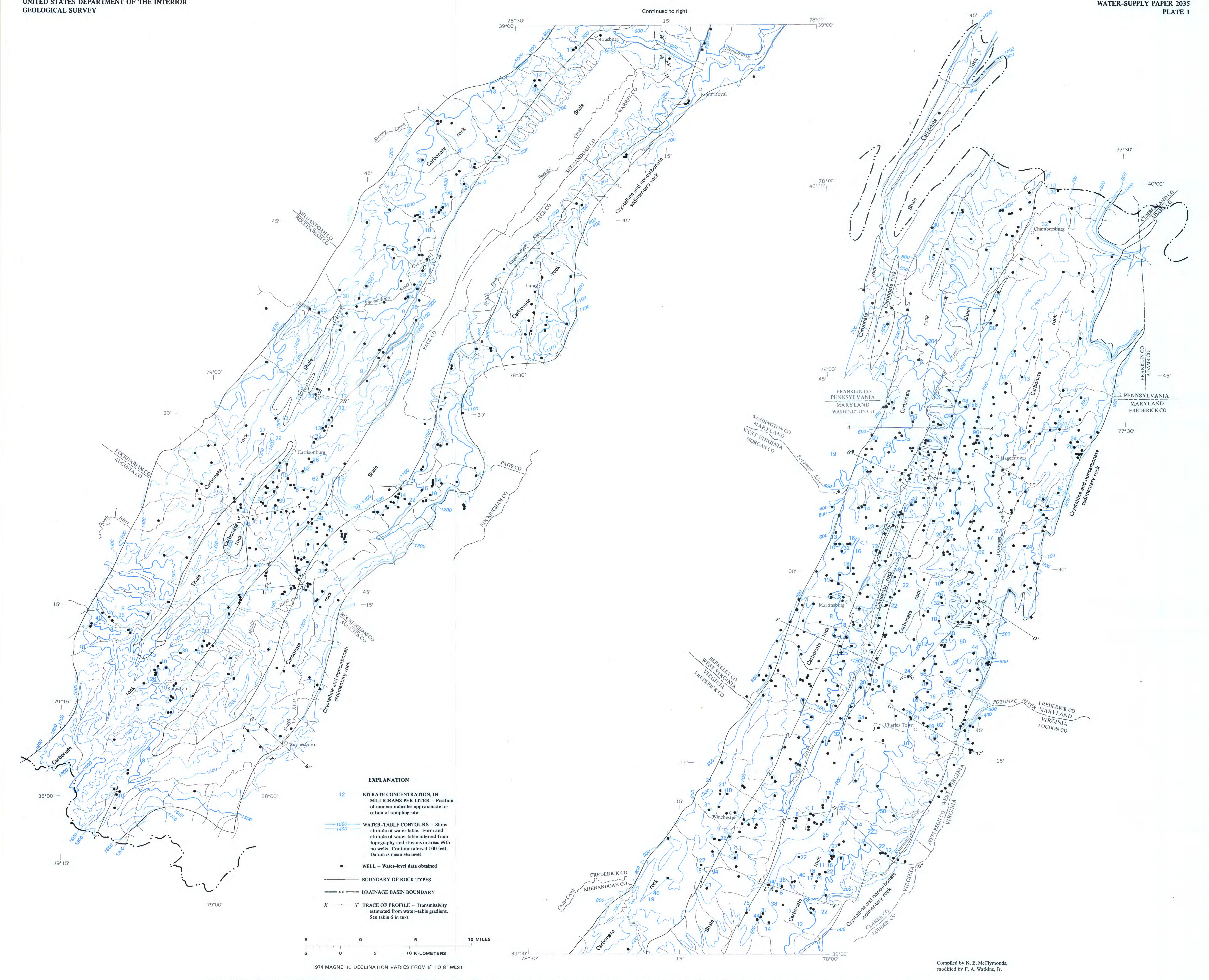

MAP SHOWING ALTITUDE AND CONFIGURATION OF WATER TABLE AND NITRATE CONCENTRATION IN GROUND WATER (FEBRUARY-MARCH 1970) IN THE LOWLAND PART OF THE APPALACHIAN VALLEY, UPPER POTOMAC RIVER BASIN 